\title{
Light-absorbing impurities in Arctic snow
}

\author{
S. J. Doherty ${ }^{1}$, S. G. Warren ${ }^{2}$, T. C. Grenfell ${ }^{2}$, A. D. Clarke ${ }^{3}$, and R. E. Brandt ${ }^{2}$ \\ ${ }^{1}$ Joint Institute for the Study of Atmosphere and Ocean, 3737 Brooklyn Ave NE, Seattle, WA 98195, USA \\ ${ }^{2}$ Department of Atmospheric Sciences, Box 351640, University of Washington, Seattle, WA 98195, USA \\ ${ }^{3}$ School of Ocean and Earth Sciences and Technology, University of Hawaii, Honolulu, Hawaii 96822, USA
}

Received: 20 July 2010 - Published in Atmos. Chem. Phys. Discuss.: 10 August 2010

Revised: 4 November 2010 - Accepted: 20 November 2010 - Published: 9 December 2010

\begin{abstract}
Absorption of radiation by ice is extremely weak at visible and near-ultraviolet wavelengths, so small amounts of light-absorbing impurities in snow can dominate the absorption of solar radiation at these wavelengths, reducing the albedo relative to that of pure snow, contributing to the surface energy budget and leading to earlier snowmelt. In this study Arctic snow is surveyed for its content of lightabsorbing impurities, expanding and updating the 19831984 survey of Clarke and Noone. Samples were collected in Alaska, Canada, Greenland, Svalbard, Norway, Russia, and the Arctic Ocean during 1998 and 2005-2009, on tundra, glaciers, ice caps, sea ice, frozen lakes, and in boreal forests. Snow was collected mostly in spring, when the entire winter snowpack is accessible for sampling. Sampling was carried out in summer on the Greenland Ice Sheet and on the Arctic Ocean, of melting glacier snow and sea ice as well as cold snow. About 1200 snow samples have been analyzed for this study.

The snow is melted and filtered; the filters are analyzed in a specially designed spectrophotometer system to infer the concentration of black carbon (BC), the fraction of absorption due to non-BC light-absorbing constituents and the absorption Ångstrom exponent of all particles. This is done using BC calibration standards having a mass absorption efficiency of $6.0 \mathrm{~m}^{2} \mathrm{~g}^{-1}$ at $550 \mathrm{~nm}$ and by making an assumption that the absorption Angstrom exponent for $\mathrm{BC}$ is 1.0 and for non-BC light-absorbing aerosol is 5.0. The reduction of snow albedo is primarily due to $\mathrm{BC}$, but other impurities, principally brown (organic) carbon, are typically responsible for $\sim 40 \%$ of the visible and ultraviolet absorption. The meltwater from selected snow samples was saved for chemical analysis to identify sources of the impurities. Median $\mathrm{BC}$ amounts in surface snow are as follows (nanograms of carbon per gram of snow): Greenland 3, Arctic Ocean snow
\end{abstract}

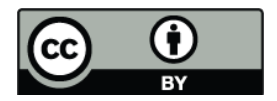

Correspondence to: S. J. Doherty (sarahd@atmos.washington.edu)
7, melting sea ice 8, Arctic Canada 8, subarctic Canada 14, Svalbard 13, Northern Norway 21, western Arctic Russia 27, northeastern Siberia 34. Concentrations are more variable in the European Arctic than in Arctic Canada or the Arctic Ocean, probably because of the proximity to BC sources. Individual samples of falling snow were collected on Svalbard, documenting the springtime decline of BC from March through May.

Absorption Ångstrom exponents are 1.5-1.7 in Norway, Svalbard, and western Russia, 2.1-2.3 elsewhere in the Arctic, and 2.5 in Greenland. Correspondingly, the estimated contribution to absorption by non-BC constituents in these regions is $\sim 25 \%, 40 \%$, and $50 \%$ respectively.

It has been hypothesized that when the snow surface layer melts some of the BC is left at the top of the snowpack rather than being carried away in meltwater. This process was observed in a few locations and would cause a positive feedback on snowmelt.

The BC content of the Arctic atmosphere has declined markedly since 1989 , according to the continuous measurements of near-surface air at Alert (Canada), Barrow (Alaska), and $\mathrm{Ny}$-Ålesund (Svalbard). Correspondingly, the new BC concentrations for Arctic snow are somewhat lower than those reported by Clarke and Noone for 1983-1984, but because of methodological differences it is not clear that the differences are significant. Nevertheless, the BC content of Arctic snow appears to be no higher now than in 1984, so it is doubtful that BC in Arctic snow has contributed to the rapid decline of Arctic sea ice in recent years.

\section{Introduction}

Most of the Arctic land and ocean areas are covered by snow in winter and spring. Snow persists through the summer on the Greenland Ice Sheet and on numerous smaller ice caps. The high albedo of snow, typically $70-80 \%$ for aged snow, is

Published by Copernicus Publications on behalf of the European Geosciences Union. 
therefore a primary determinant of the Arctic climate during the sunlit seasons. Because the albedo is so high, it can be reduced by small amounts of absorptive impurities. The absorption coefficient of ice is extremely small at visible wavelengths but becomes much larger in the near-infrared (Warren and Brandt, 2008), where albedo is sensitive to grain size (Wiscombe and Warren, 1980). The reduction of albedo by absorptive impurities is mostly confined to visible and nearultraviolet wavelengths, as shown by radiative transfer modeling (Warren and Wiscombe, 1980).

Spectral albedo was measured for snow-covered sea ice at the field camp on the ice island T-3 in the Arctic Ocean (Grenfell and Maykut, 1977); the albedo at visible wavelengths was lower than predicted for pure snow. It was possible to explain the albedo spectrum by addition of a spectrally flat (gray) absorber such as black carbon (BC, a major component of soot) to the radiative-transfer model, but not by addition of a colored absorber such as soil dust (Warren and Wiscombe, 1980; Warren, 1982). Black carbon is produced by incomplete combustion for sources like diesel engines, coal burning, forest fires, agricultural fires, and residential wood burning (Bond et al., 2004). When injected into the atmosphere, these particles may travel thousands of kilometers before they are removed by rain or snow precipitation.

The soot in snow at T-3 most likely came from local sources at the research camp, but the resulting dramatic reduction of albedo raised the question of how much soot is normally present in the Arctic snowpack and how much it could reduce the albedo. The Arctic troposphere is known to contain dark layers in winter and early spring that often extended over the entire Arctic Ocean, called "Arctic haze" (Schnell, 1984; Raatz and Shaw, 1984; Shaw, 1995). Its radiative effects have been estimated by Cess (1983) and others. The soot in Arctic haze eventually is removed from the atmosphere, either scavenged by falling snow crystals or by dry deposition, which can be augmented by the filtering effect of snow (Harder et al., 1996). Concentrations of BC in the snow are determined by the ambient concentrations in air and these wet and dry depositional processes, by the snowfall rate, and, with aging, by in-snow processes such as frost deposition, sublimation and melting.

The pioneering study to measure soot in Arctic snow was carried out by Clarke and Noone (1985; hereafter CN85). They obtained 60 snow samples from volunteers in Alaska, Canada, Greenland, Svalbard, and Fram Strait during 1983 and 1984. The snow samples were then melted and filtered. The spectral transmission of each filter was measured using "integrating plate" and "integrating sandwich" configurations (Clarke, 1982; Clarke et al., 1987), and compared to that of standard filters containing known (weighed) amounts of a calibration soot (Monarch-71). The slope of absorption versus wavelength indicated that the dominant absorber was gray and therefore probably soot.

The soot amounts inferred by CN85 were mostly in the range 5-50 nanograms of carbon per gram of snow ( $\mathrm{ng} \mathrm{g}^{-1}$, or ppb by mass), which could reduce the broadband (0.3$2.8 \mu \mathrm{m}$ ) albedo of snow by as much as 0.04 , depending on snow grain size (Warren and Wiscombe, 1985). CN85 suggested a mean value of $25 \mathrm{ng} \mathrm{g}^{-1}$ for the Arctic, and a corresponding albedo reduction of 0.02 (CN85; Warren and Clarke, 1986). An albedo reduction of this magnitude is not detectable by eye and is below the accuracy of satellite observations, but it is significant for climate (Hansen and Nazarenko, 2004; Jacobson et al., 2004; Hansen et al., 2005; Flanner et al., 2007).

The radiative forcing caused by such a reduced snow albedo depends on the seasonal cycle of snow-cover fraction and the extent to which snow is masked by vegetation or hidden under clouds. The radiative forcing was computed in the Goddard Institute for Space Studies General Circulation Model (GISS GCM) by Hansen and Nazarenko (2004). The resulting warming was larger than expected for the computed radiative forcing. There are several possible reasons: (1) the peak of soot fallout in the Arctic occurs in spring, coinciding with the onset of snowmelt; (2) melting (coarse-grained) snow has lower albedo than cold (fine-grained) snow; (3) earlier melt exposes a dark underlying surface; and (4) the stable atmospheric boundary layer over snow prevents rapid heat exchange with the free troposphere, concentrating the warming at the surface. For a specified radiative forcing, sootin-snow had 1.8 times the climatic warming effect of anthropogenic $\mathrm{CO}_{2}$, giving soot-in-snow an "efficacy" of 1.8 (Hansen et al., 2005). Subsequent climate modeling by Flanner et al. (2007), incorporating snow processes into a GCM, found an even higher efficacy of 3.2, because of several additional considerations: (5) an initial albedo reduction causes a temperature increase and therefore growth of snow grain size, even before the onset of melting (LaChapelle, 1969; Flanner and Zender, 2006) and further reducing albedo; (6) soot causes greater albedo reduction in coarse-grained snow than in fine-grained snow (Fig. 7 of Warren and Wiscombe, 1980); and (7) it has been hypothesized that melting may tend to concentrate soot at the top surface (e.g. in the modeling study of Flanner al., 2007), where it is exposed to more sunlight. The radiative effects of $\mathrm{BC}$ in snow are now the subject of several additional modeling efforts (Jacobson, 2004; Koch and Hansen, 2005; Koch et al., 2009) and summary assessments (Quinn et al., 2008).

Although BC is the most absorptive impurity per unit mass, it is not the only important absorber in snow. By comparing Figs. 4 and 7 of Warren and Wiscombe (1980), Warren (1984) concluded that soil dust is about a factor of 50 less effective (per unit mass) at reducing snow albedo. However, in some locations so much dust is deposited to the snow that dust is the dominant absorber. This was shown by Painter et al. (2007) for snow in the mountains of Colorado.

We report here on a new survey of absorptive impurities in Arctic snow, using a modified version of the method used by CN85. The goals of the survey are: 
1. to obtain better geographical coverage including in regions that were missing in the 1985 study (the central Arctic Basin and Russia);

2. to obtain better spatial resolution and vertical profiles (>1200 samples total, compared to 60 for CN85);

3. to distinguish the absorption of radiation by black carbon from the absorption by other constituents, principally organic carbon ("brown carbon") and soil dust; and

4. to determine the change in anthropogenic pollution of the Arctic snow since 25 years ago.

\section{Strategy}

The presence of $\mathrm{BC}$ in snow can have a climatic effect wherever large areas of snow are exposed to significant solar energy. In the Arctic the maximum effect should be on tundra and sea ice during spring, and on the Greenland Ice Sheet in summer. We put most of our effort into sampling these regions. The boreal forests of Canada and Russia should be much less affected because snowfall there lies at the base of the vegetation and thus shielded from sunlight. However, even in the forest it can be useful to measure BC in snow, for evaluation of chemical transport and deposition models, so we do include some lower-latitude snow samples in our survey.

Snowmelt on the Arctic tundra proceeds rapidly during May and June (Potter, 1965; Kopanev and Lipovskaya, 1978; Grenfell and Perovich, 2004; Aleksandrov et al., 2005). By early July the snow is gone from the Arctic Ocean (Fig. 13 of Warren et al., 1999), but some of the BC is left on the surface (Perovich et al., 2009), where it can reduce the albedo of melting sea ice. The reduction of surface albedo by $\mathrm{BC}$ can therefore continue through the summer in some regions. We have designed our sampling strategy accordingly, collecting snow from the tundra in spring, but from the Arctic Ocean and the Greenland Ice Sheet in both spring and summer.

Most of the snow samples were collected in April or May, when the snowpack is near its maximum depth and before the onset of melting, so that the snow stratigraphy in a vertical profile would provide samples of snow that fell at different times during the accumulation season. We organized several expeditions ourselves but also obtained numerous snow samples from volunteers who were carrying out research in the Arctic for other purposes. On our own expeditions we obtained vertical profiles, but much of the sampling by volunteers obtained only surface samples or vertically-integrated samples. In addition to collecting snow, we also measured the vertical profile of snow density, so that our reported concentration of impurities (e.g., $\mathrm{ng} \mathrm{BC}^{-1}$ snow) can be used to compute the deposition flux (e.g. $\mathrm{g} \mathrm{BC} \mathrm{m}^{-2}$ month $^{-1}$ ), although that conversion is not carried out in this paper. At each site we normally collected two vertical profiles separated horizontally by $50-100 \mathrm{~cm}$. This allowed us to check for the representativeness of our measurements and to screen for possible contamination during the sampling process.

$\mathrm{BC}$ is often hydrophobic, so as the snow melts it may be left behind at the surface, where it has a greater effect on albedo than if uniformly distributed. To investigate the vertical redistribution of $\mathrm{BC}$, we obtained vertical profiles of $\mathrm{BC}$ in melting snow at two locations.

In the Arctic Ocean, some of the sea ice is heavily laden with sediment, picked up by ice freezing to the sea floor on the shallow Siberian shelf, particularly in the Kara, Laptev, and East Siberian seas (Frey et al., 2001; Ivanov, 2005; Eicken et al., 2003, 2005). In subsequent years the sediment rises as the upper ice surface melts and new ice freezes to the base. After it reaches the upper surface, the sediment is exposed each year after the snow melts, and it reduces the albedo of the melting multiyear ice. We did not sample sediment-laden ice, focusing our work instead on impurities that reached the snow and ice by transport through the atmosphere. We are unaware of published estimates of the fractional area of Arctic sea ice covered by such sediment, but from observations on icebreaker voyages by ourselves and others, we think it is $\sim 10 \%$ (H. Eicken and D. Darby, personal communications, 2010).

Although the motivation for our work is the reduction of snow albedo, we do not present albedo measurements in this paper. The expected reduction in albedo of Arctic snow due to $\mathrm{BC}$ is only $1-2 \%$, which is significant for climate but difficult to resolve experimentally because snow albedo depends on several other variables, principally snow grain size. To assess the effect of BC (and other impurities) on snow albedo our recommended procedure is to measure the $\mathrm{BC}$ content of snow and then use a radiative-transfer model to compute the albedo reduction. That procedure requires experimental verification, which is underway using artificial snowpacks with large, quantified soot contamination to obtain a large signal on albedo (Brandt et al., 2010).

\section{Method}

\subsection{Collection of snow}

Snow pits were dug in locations far from roads and villages, so that the data would represent large areas and be unaffected by local sources of pollution. Facing upwind, the operator, wearing clean dust-free disposable rubber over-gloves, used a stainless-steel spatula to put snow into a plastic bag (or alternatively, pushed a glass jar into the snow). A photograph of the procedure was shown by Tollefson (2009). It is important to test for artifacts caused by the sampling procedure. For example, some kinds of plastic bags can be scratched by snow, producing plastic flakes in the meltwater that can scavenge soot. Samples sizes of 500-1500 g were used for 
most Arctic locations. Typically samples would be collected at vertical intervals of $5 \mathrm{~cm}$ throughout the snowpack, which rarely exceeded $30 \mathrm{~cm}$ total depth. Duplicate samples were collected at each layer. If there was obvious layering, for example a thin top layer of newly fallen snow or drift snow, that layer was collected separately, however thin.

On some of the early expeditions, snow was collected in plastic bags that did shed flakes which scavenged soot from meltwater. Tests using multiple samples of the same snow layer collected in different ways indicated an average loss of $20 \%$ to the flakes. We have therefore multiplied BC concentrations in those samples (Canada 2007 and Russia 2007) by a factor of 1.2.

It was not feasible to provide training in the field to all volunteers. However, the BC values for samples collected by volunteers fall within the range of samples collected by us in nearby regions, so we think contamination by personnel during the snow-sampling process was negligible and has not affected the results.

\subsection{Filtration}

The snow was kept frozen until it could be processed; then it was spooned into a clean glass beaker and melted quickly in a microwave oven. The meltwater was passed through a filter, using a hand-pump to create a partial vacuum, and the volume of filtrate measured. The melting typically required 3$5 \mathrm{~min}$, and the filtration another $3-5 \mathrm{~min}$. This procedure was designed to minimize the time that meltwater was in contact with glass or plastic, because soot is often hydrophobic, and some could be lost to the container walls instead of collected on the filter (Ogren et al., 1983; CN85). Another reason for keeping the snow frozen until ready for processing was to avoid algal growth since algae can change the water chemistry as well as absorbing light themselves. This procedure is essentially the same method we used to survey snow at the South Pole (Warren and Clarke, 1990), at Vostok Station (Fig. 10 of Grenfell et al., 1994), at Dome C Station (Fig. 6 of Warren et al., 2006), and in the Arctic Ocean (Grenfell et al., 2002).

For routine processing, we used $0.4-\mu \mathrm{m}$ nuclepore filters, as were used by CN85. These were occasionally backed up by a $0.2-\mu \mathrm{m}$ filter to assess the undercatch, which varied from 0 to $30 \%$ depending on location (because the size distribution of particles varies with location), averaging $15 \%$. This agrees with the finding of $\mathrm{CN} 85$ that the 0.4- $\mu \mathrm{m}$ filters collected 85$88 \%$ of the BC in the samples of Arctic snow from Svalbard and Greenland. Filtration through the $0.2-\mu \mathrm{m}$ filter was too slow for routine use. The extra time required would enhance the risk of losses of soot to the walls of the funnel and the $0.2-\mu \mathrm{m}$ filters are easily clogged by non-absorptive impurities (probably biopolymers) that are often present in Arctic snow. To account for the undercatch by the $0.4-\mu \mathrm{m}$ filter, the derived concentrations were multiplied by a factor of 1.15 for presentation in this paper.
For washing our glassware at locations where distilled water was not available, we used the filtrate of our melted snow; this gave results no different than when we washed with distilled water. For example, at the Antarctic stations at South Pole and Vostok, we reliably analyzed snow with very low background levels of $\mathrm{BC}\left(0.1-0.7 \mathrm{ng} \mathrm{g}^{-1}\right)$, and were able to make contour-maps of the $\mathrm{BC}$ content of snow in the vicinity of the stations (Warren and Clarke, 1990; Grenfell et al., 1994). Duplicate samples there were in good agreement.

Small samples of meltwater, both before and after filtration, were taken and refrozen for later chemical analysis, to be used in source-attribution studies (Hegg et al., 2009, 2010). All sample collection containers were cleaned thoroughly at each new site with distilled water, if available, or with filtered meltwater from the new site to avoid biasing the chemical signatures.

\subsection{Spectrophotometry}

The transmittance spectrum of each filter was measured in an integrating-sandwich spectrophotometer that incorporates an integrating sphere as one side of the sandwich (ISSW; Grenfell et al., 2010). The integrating-sandwich configuration is designed to minimize the effect of scattering by the aerosols on the filter, so that the measured signal is a function only of the losses due to light absorption. A set of standard filters containing known (weighed) amounts of BC in the form of Monarch-71 soot was used to calibrate the system for conversion from measured signal to black carbon loading $\left(\mu \mathrm{gC} \mathrm{cm}{ }^{2}\right.$ on the filter). The calibration standards were pre-filtered to produce a size distribution generally representative of atmospheric BC $(0.4 \mu \mathrm{m}$ mass mean diameter). These standards were determined to have a mass absorption coefficient of $6 \mathrm{~m}^{2} \mathrm{~g}^{-1}$, by the methods of CN85 and Clarke et al. (1987). The most heavily loaded calibration standard has a concentration of $\sim 30 \mu \mathrm{gC} \mathrm{cm}{ }^{2}$. Above this concentration, the attenuation of light through the filter causes the ISSW signal-tonoise ratio to become unacceptably low. Therefore, for this study we rejected the filter samples with loadings higher than this ( $<5 \%$ of all samples).

The quantity required for radiative transfer modeling of a snowpack is the bulk snow density of the snow and the absorption coefficient $k_{\mathrm{abs}}\left(\mathrm{m}^{2}\right.$ of absorption cross-section per gram of snow). (Multiplied together, they give the linear absorption coefficient in units of $\mathrm{m}^{-1}$ ). From the filter measurement, $k_{\mathrm{abs}}$ is obtained as the absorption cross-section of particles on the filter, divided by the mass of meltwater passed through the filter. For convenience in relating our results to the predictions of atmospheric transport and deposition models, we calculated $C$, the concentration of $\mathrm{BC}$ in snow, using the relation:

$k_{\mathrm{abs}}=\beta_{\mathrm{abs}} C$,

where $C$ has units $(\mathrm{g} \mathrm{BC}) /\left(\mathrm{g}\right.$ snow), and $\beta_{\mathrm{abs}}$ is the massabsorption cross-section (MAC) of $\mathrm{BC}\left(\mathrm{m}^{2} \mathrm{~g}^{-1}\right)$. There is 
ongoing research to determine the optical properties of $\mathrm{BC}$ (Clarke et al., 1987, 2004; Bond and Bergstrom, 2006). Bond and Bergstrom's comprehensive review recommends $\beta_{\text {abs }}=7.54 \mathrm{~m}^{2} \mathrm{~g}^{-1}$ at $\lambda=550 \mathrm{~nm}$, which agrees with the results of Clarke et al. (2004). This number will vary depending on the type of soot and its size distribution.

However, to estimate the radiative forcing by $\mathrm{BC}$ in snow, what we really need to know is not the mass of $\mathrm{BC}$ but rather its effect on snow albedo, which is closely related to its absorptance on the filter. We report here an effective BC mass concentration, which would actually be the true mass concentration if the absorber in the sampled snow were identical to the soot that was used to make the weighed standards. If $\beta_{\text {abs }}$ for the sample aerosol is in fact closer to $7.5 \mathrm{~m}^{2} \mathrm{~g}^{-1}$ (as suggested by Bond and Bergstrom, 2006) rather than $6.0 \mathrm{~m}^{2} \mathrm{~g}^{-1}$ ( $\beta_{\text {abs }}$ of our calibration filters) our concentrations will accordingly be too high - i.e. by $\sim 25 \%$ ). If the concentrations reported in this paper are used in radiation models, they should be used with $\beta_{\mathrm{abs}}=6.0 \mathrm{~m}^{2} \mathrm{~g}^{-1}$ at $\lambda=550 \mathrm{~nm}$, or else scaled appropriately.

As noted by Grenfell et al. (2010), the ISSW photometer measures all light-absorbing aerosol (LAA). If the objective is to estimate radiative forcing rather than the carbon mass budget, an advantage of the filter method is that it is a measure of absorption, which is closely related to the absorption of sunlight in the snowpack. Further, we can use the wavelength-dependence of the measured absorption to derive a best estimate of the $\mathrm{BC}$ mass as well as several other useful quantities, as described in more detail by Grenfell et al. (2010):

- $C_{\mathrm{BC}}^{\max }\left(\mathrm{ng} \mathrm{g}^{-1}\right)$ : maximum $B C$ is the mass of black carbon per mass of snow, if all aerosol light absorption at $650-700 \mathrm{~nm}$ is due to $\mathrm{BC}$.

- $C_{\mathrm{BC}}^{\mathrm{est}}\left(\mathrm{ng} \mathrm{g}^{-1}\right)$ : estimated $B C$ is the estimated true mass of black carbon per mass of snow, derived by separating the spectrally-resolved total light absorption into $\mathrm{BC}$ and non-BC fractions based on the absorption Ångstrom exponent $\left(\AA_{\text {tot }}\right)$ of the material on the filter, and by assigning absorption Ångstrom exponents (measured $450-600 \mathrm{~nm}$ ) of 1.0 and 5.0 to BC and non-BC lightabsorbing aerosol (LAA) respectively.

$-C_{\mathrm{BC}}^{\text {equiv }}\left(\mathrm{ng} \mathrm{g}^{-1}\right)$ : equivalent $B C$ is the amount of black carbon that would need to be present in the snow to account for the wavelength-integrated total light absorption from 300 to $750 \mathrm{~nm}$.

- $\AA_{\mathrm{tot}}:$ absorption Angstrom exponent, calculated between $450 \mathrm{~nm}$ and $600 \mathrm{~nm}$, for all LAA deposited on the filter.

- $f_{\text {nonBC }}^{\text {est }}$ fraction of light absorption by non-BC LAA, weighted by the downwelling solar flux then spectrally integrated.
The values $C_{\mathrm{BC}}^{\max }$ and $C_{B C}^{\mathrm{est}}$ can be used to test model representation of the black carbon content of snow. $\AA_{\text {tot }}$ has been measured for atmospheric aerosol and tends to have a characteristic range of values for specific source types and thus can provide a helpful if not definitive indicator of aerosol source, as well as providing information helpful for determining the spectral absorption of sunlight in the snowpack.

While the focus of most studies of radiative forcing by light absorbing aerosol (LAA) in snow has been on black or elemental carbon, as is shown below a significant fraction (typically 20-50\%) of light absorption in the snowpack is caused by non-BC LAA. Studies that account for light absorption only by $\mathrm{BC}$ can use the quantity $C_{\mathrm{BC}}^{\text {equiv }}$ as a proxy for how much $\mathrm{BC}$ would be needed to account for light absorption by all LAA in the snowpack.

As indicated above, to derive $C_{\mathrm{BC}}^{\text {est }}$ and $f_{\text {nonBC }}^{\text {est }}$ we assume values for the absorption Ångstrom exponent $(450-600 \mathrm{~nm})$ of 1.0 for black carbon $\left(\AA_{\mathrm{BC}}\right)$ and 5.0 for the non-BC LAA ( $\left.\AA_{\text {nonBC }}\right)($ Grenfell et al., 2010). We base these choices on observations that indicate $\mathrm{BC}$-dominated real atmospheric aerosol near the source (i.e., where the aerosol has not yet internally mixed with or been coated by other constituents) generally has $\AA_{\mathrm{BC}} \approx 1.0$ (Rosen et al., 1978; Bond et al., 1999; Bond, 2001; Bergstrom et al., 2002, 2007; Kirchstetter et al., 2004; Schnaiter et al., 2003, 2005; Clarke et al., 2007). Our assumed value of $\AA_{\text {nonBC }}=5.0$ is consistent with (Kirchstetter et al., 2004; $\AA_{\text {nonBC }} \approx 5.6$, calculated from his Table 4), (Roden et al., 2006; by using the highest measured values of $\AA_{\text {nonBC }} \approx 5$ when absorption by $\mathrm{BrC}$ vs. BC was highest), (Sun et al., 2007; who found $\AA_{\text {nonBC }}=4$ for humiclike organic carbon and 6 for more polymerized organic carbon). However, we acknowledge that $\AA_{\text {nonBC }}$ is highly uncertain. Furthermore, the source of LAA to the snow likely differs from region to region, so we may have high biases in $C_{\mathrm{BC}}^{\text {est }}$ (low biases in $f_{\text {nonBC }}^{\text {est }}$ ) in one location but low (high) biases in another region. The values used here are appropriate for light-absorbing ("brown") organic carbon found in combustion aerosols or soil. Mineral dust may also absorb light and has also been found to have a range of values of $\AA$, but the source attribution studies of Hegg et al. $(2009,2010)$ indicate that most of the non-BC LAA in our samples is brown carbon, not dust. Samples with the highest values of $\AA_{\text {tot }}$ will have the largest uncertainties in $C_{\mathrm{BC}}^{\text {est }}$ and $f_{\text {nonBC }}^{\text {est }}$ since a larger fraction of light absorption is attributable to non-BC constituents (Fig. 1); the magnitude of these uncertainties is discussed explicitly in Sect. 6. We note that the partitioning of absorption due to $\mathrm{BC}$ vs. dust in the original CN85 survey was also based on $\AA$, but this was before the influence of "brown carbon" was recognized. 

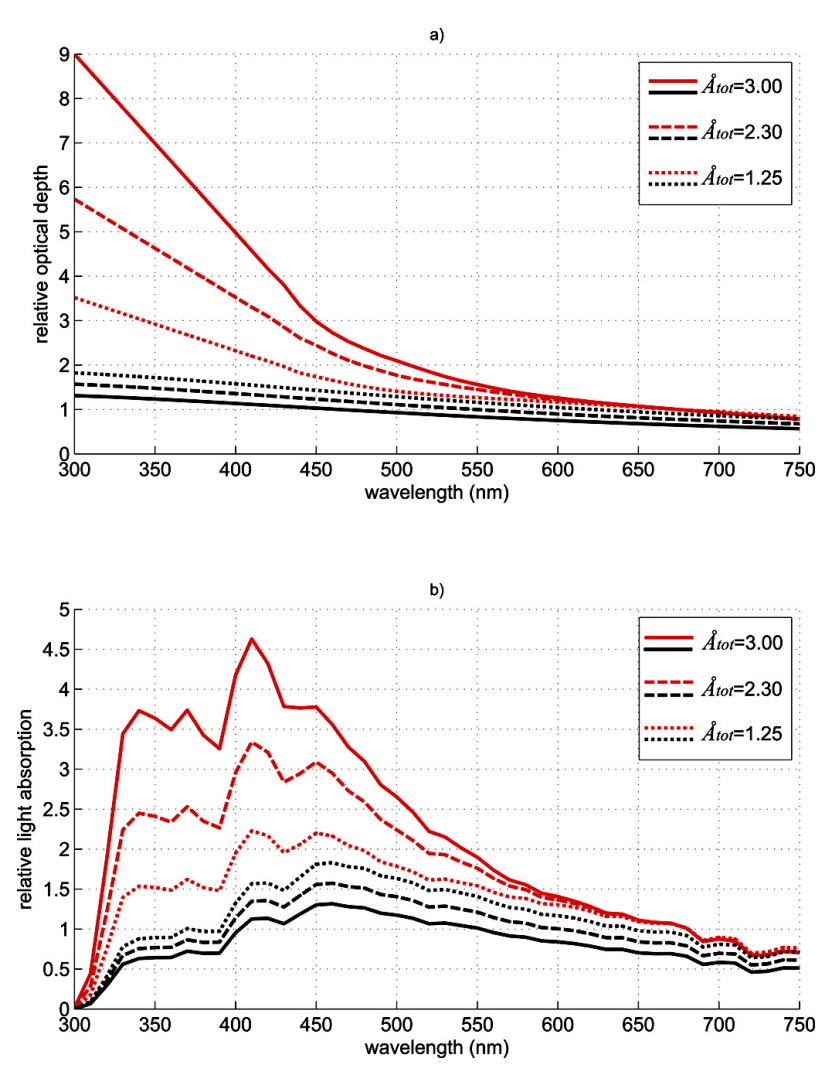

Fig. 1. Relative optical depth for absorption (top), weighted by the downwelling solar radiation (bottom) for all light-absorbing aerosol (red) and for BC only (black) for three sample filters covering a range of values of $\AA_{\text {tot }}$ measured in our survey. The ratio of the area between the black curve and the red curve to the area under the red curve (bottom panel) gives $f_{\text {nonBC }}^{\text {est }}$, which for the three cases shown is $64 \%$ ( $\AA_{\text {tot }}=3.00$; Canadian Arctic sample), $45 \%\left(\AA_{\text {tot }}=2.30\right.$; sample near the North Pole $)$ and $18 \%\left(\AA_{\text {tot }}=1.25\right.$; Svalbard sample).

\subsection{Alternative methods}

Other methods that have been used to measure BC in Arctic snow and ice are the thermo-optical (TO) method and the single-particle soot photometer (SP2). The studies that have used those methods are cited in the appropriate sections below. The TO method is a controlled-combustion method. The $\mathrm{CO}_{2}$ given off by oxidation of material on a filter is measured as the filter is exposed to successively higher temperatures. Organic carbon (OC) is oxidized at a lower temperature than elemental carbon, but some of the OC instead becomes charred (converted to $\mathrm{BC}$ ), so the transmittance or reflectance of the filter is monitored to correct for this artifact. Various versions of the TO method have been used, with different temperatures for the oxidation stages and different optical arrangements, giving results that commonly differ by factors of 2 and as much as a factor of 7 (Watson et al., 2005). The method has been critically analyzed by Boparai et al. (2008).
The SP2 counts individual particles of $\mathrm{BC}$, obtaining a size distribution for particles of $70-700 \mathrm{~nm}$ diameter. The method was designed for sampling aerosols but has been adapted for use with meltwater from ice cores by McConnell et al. (2007). The calibration of the SP2 is still a subject of research; recent intercomparisons have been reported by Slowik et al. (2007) and Cross et al. (2010).

Our filter-transmission method does not definitively quantify the mass of BC separately from that of brown carbon and dust. As mentioned above, an advantage of our method is that it is a measure of absorption, so it is directly related to absorption of solar radiation in a snowpack, unlike the TO and SP2 methods. A further advantage is that the filtering can be carried out at a field camp or in a hotel room, without the need to return large quantities of snow in frozen shipments to our home laboratory.

\section{Locations sampled}

Figure 2 shows the overall distribution of sampling, and Table 1 summarizes the field campaigns. Abbreviations of the institutions involved, and other abbreviations, are given in Appendix A. Other important characteristics of the individual measurement campaigns are discussed in the following paragraphs.

\subsection{Arctic Ocean (Fig. 2)}

We now have good coverage of the central Arctic Ocean from the expeditions listed in Table 1. Samples were obtained in both spring and summer, of new snow, old cold snow, melting snow, and melting sea ice.

In 1997 a ship was frozen into the ice of the Beaufort Sea for the Surface Heat Balance of the Arctic (SHEBA) project. In April 1998 a thorough study of BC in snow was carried out in the region surrounding the ship. The results were published by Grenfell et al. (2002) and have been re-analyzed with the ISSW Spectrophotometer. Nine years later, early-April snow was collected in the vicinity of another stationary ship, also in the Beaufort Sea, as part of the APLIS/SEDNA project.

In 2005 a summer transect of the Arctic Ocean was carried out by the ships Oden and Healy (HOTRAX project) from the Bering Strait to Fram Strait. Grenfell collected samples of the surface granular layer of melting sea ice, aged snow and newly-fallen snow from mid-August through late September. Preliminary estimates of BC from this voyage were published by Perovich et al. (2009).

In a summer voyage in the Beaufort Sea by researchers from the University of Victoria in 2008, aged snow and the granular surface layer of melting sea ice were sampled. Newly fallen snow was also available at some locations.

For several years the North Pole Environmental Observatory (NPEO) has been operating for the month of April at the 
Table 1. Field campaigns within each region, listed in order of the number of snow samples obtained.

\begin{tabular}{|c|c|c|c|c|c|c|c|c|}
\hline Region & Year & Month & $\begin{array}{l}\text { Number } \\
\text { of sites }\end{array}$ & $\begin{array}{l}\text { Number } \\
\text { of snow } \\
\text { samples }\end{array}$ & $\begin{array}{r}\text { Number } \\
\text { of vertical } \\
\text { profiles }{ }^{1}\end{array}$ & $\begin{array}{r}\text { Number } \\
\text { of water } \\
\text { samples } \\
\text { saved }\end{array}$ & $\begin{array}{l}\text { Institution } \\
\text { responsible }\end{array}$ & Comment \\
\hline \multicolumn{9}{|l|}{ Arctic Ocean } \\
\hline Chukchi and Beaufort Seas & 1998 & mid-Apr-May & 2 & 66 & 0 & 0 & UW & SHEBA campaign; one site \\
\hline Bering Strait to Fram Strait & 2005 & mid-Aug-Sep & 22 & 54 & 3 & 0 & UW & $\begin{array}{l}\text { HOTRAX campaign; transect } \\
\text { across Arctic Ocean }\end{array}$ \\
\hline Beaufort Sea & 2008 & Jul-Aug & 13 & 37 & 0 & 43 & UVic & Transect $\sim 76^{\circ}-82^{\circ} \mathrm{N}$ \\
\hline Beaufort Sea & 2007 & Early Apr & 1 & 17 & 0 & 1 & CRREL, UDel & $\begin{array}{l}\text { APLIS/SEDNA campaign; } \\
\text { one site }\end{array}$ \\
\hline $88-90^{\circ} \mathrm{N}$ & 2007 & Late Apr & 5 & 5 & 0 & 6 & NW Passage & \\
\hline 5 sites north of Greenland & 2008 & Apr & 4 & 4 & 0 & 2 & UW & Switchyard campaign \\
\hline \multirow{2}{*}{ Near N. Pole } & 2006 & Apr & 1 & 2 & 0 & 3 & UW & NPEO \\
\hline & 2008 & & 1 & 4 & 0 & 0 & & \\
\hline \multicolumn{9}{|l|}{ Canada and Alaska } \\
\hline Canadian Arctic & 2009 & Apr-May & 24 & 256 & 24 & 134 & UW & $\begin{array}{l}\text { By Twin-Otter aircraft } \\
\text { to remote sites }\end{array}$ \\
\hline Canadian subarctic & 2007 & Mar-Apr & 27 & 51 & 0 & 12 & CRREL & $\begin{array}{l}\text { SNOWSTAR snowmobile trek., } \\
\text { Sturm et al. (2008) }\end{array}$ \\
\hline \multirow[t]{2}{*}{ N. Alaska coast } & 2008 & Apr & 1 & 6 & 0 & 5 & UW, NPI & Sea ice near Barrow \\
\hline & 2007 & May & 1 & 1 & 0 & 0 & UAF & $\begin{array}{l}\text { On McCall Glacier } \\
\text { in Brooks Range }\end{array}$ \\
\hline Ellesmere Island & 2006 & Mar & 1 & 1 & 0 & 0 & UId & Near Eureka \\
\hline \multicolumn{9}{|l|}{ Greenland } \\
\hline South Greenland & 2008 & Jul & 1 & 65 & 7 & 18 & UW & At Dye-2 in percolation zone \\
\hline Central Greenland & 2007 & Jun & 1 & 13 & 1 & 2 & UW & At Summit station \\
\hline Northeast Greenland & 2006 & Aug & 2 & 12 & 2 & 0 & $\begin{array}{l}\text { UW, UNIS, } \\
\text { GEUS }\end{array}$ & $\begin{array}{l}\text { On ice sheet in KPCL, } \\
\text { access via helicopter }\end{array}$ \\
\hline Northwest Greenland & 2007 & Jul & 2 & 9 & 2 & 2 & UW & On ice sheet above Thule \\
\hline Greenland AWS & 2007,2008 & Apr & 7 & 7 & 0 & 7 & $\mathrm{CU}$ & Numerous sites on GIS \\
\hline \multicolumn{9}{|l|}{ Russia } \\
\hline Russia, $125-175^{\circ} \mathrm{E}$ & 2008 & Mar-May & 14 & 352 & 29 & 50 & UW, AARI & Grenfell et al. (2009) \\
\hline Russia, $50-110^{\circ} \mathrm{E}$ & 2007 & Mar-May & 4 & 113 & 14 & 9 & UW, AARI & \\
\hline \multicolumn{9}{|l|}{ Svalbard and Norway } \\
\hline \multirow{3}{*}{$\begin{array}{l}\text { Svalbard } \\
\text { Norway }\end{array}$} & 2007,2009 & Mar-Apr & 4 & 108 & 3 & 48 & UW, NPI, UH & Near Ny-Ålesund \\
\hline & 2007 & Apr & 3 & 5 & 0 & 0 & UK & On sea ice around Svalbard \\
\hline & 2008 & May & 1 & 84 & 9 & 0 & UW, NPI & Mountain plateau east of Troms $\emptyset$ \\
\hline
\end{tabular}

${ }^{1}$ To qualify as a "profile", samples from at least 3 distinct snow depths were required.

North Pole for oceanographic measurements (Morison et al., 2002). Snow samples were collected at NPEO in 2006 and 2008. In April of 2008 and 2009, snow was also collected for us near several helicopter-landing sites on sea ice north of Greenland, in connection with the "Switchyard" project.

A tourist group skiing from $88^{\circ} \mathrm{N}$ to the North Pole in April 2007 collected some snow to provide samples in the region of the North Pole but remote from the NPEO station activities.

\subsection{Canada and Alaska (Fig. 3)}

In March-April 2007 Matthew Sturm led a 4200-km snowmobile trek across subarctic Alaska and Canada, terminating at Baker Lake (Sturm et al., 2008). Snow samples were collected at 28 sites, mostly remote from settlements. At each site a sample of the surface snow was collected, and also a vertically-integrated sample from 0 to $20 \mathrm{~cm}$ depth. A few of these samples were rejected because the filter loading was too high for accurate measurement. Samples from Site 11 were rejected because they were made in close proximity to the Kugluktuk copper mine.

In April-May 2009 we surveyed the Canadian Arctic Islands. A Twin-Otter ski plane was used to sample snow at 24 remote locations on frozen lakes, on sea ice, on tundra, and on small ice caps. This method was very efficient because snow unaffected by local pollution was available a short walk from the airplane. To collect 300 samples required just two weeks, by comparison to the expedition to Eastern Siberia in 2008 where two months were required to collect a similar number of samples. 


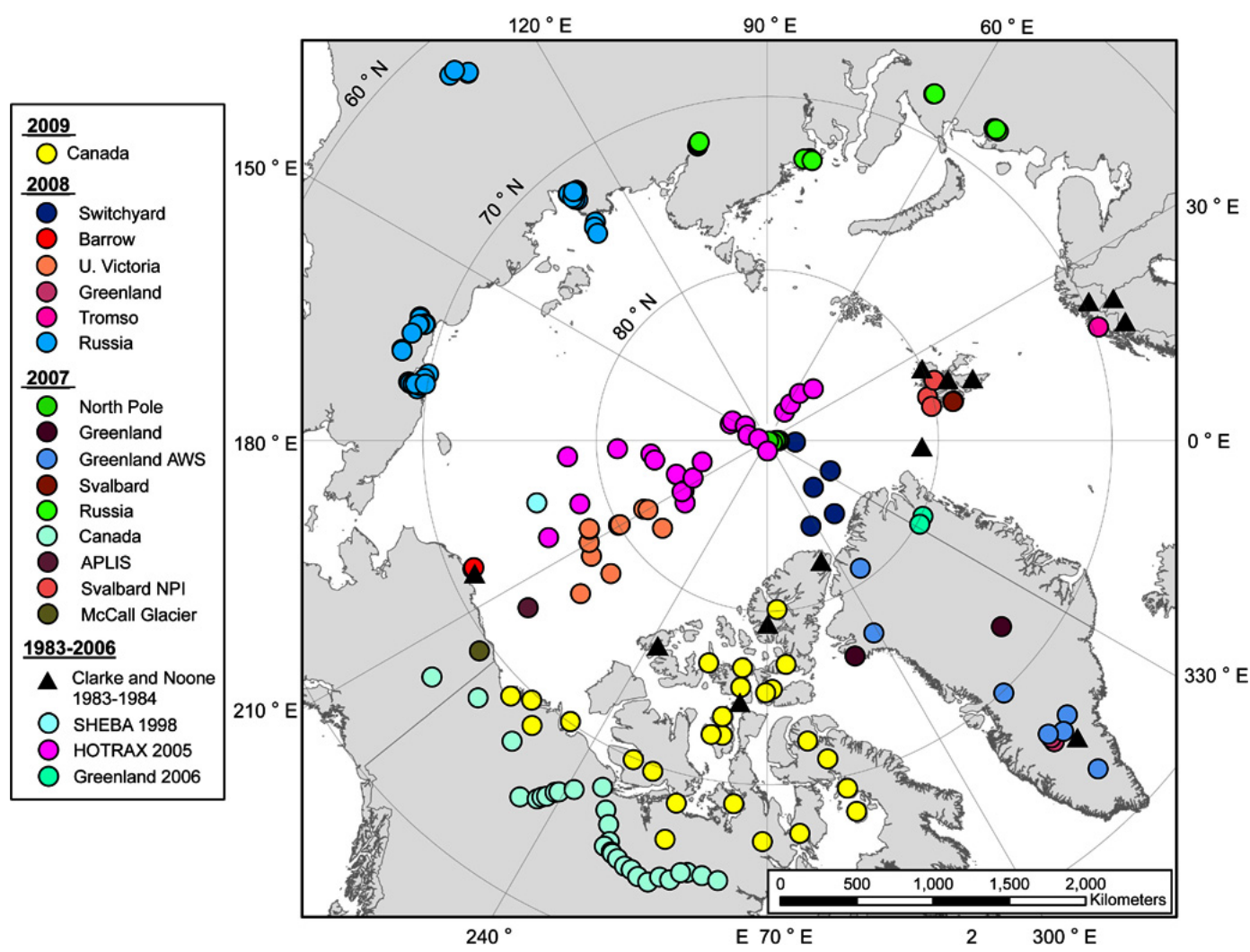

Fig. 2. All snow-sampling locations used in this paper.

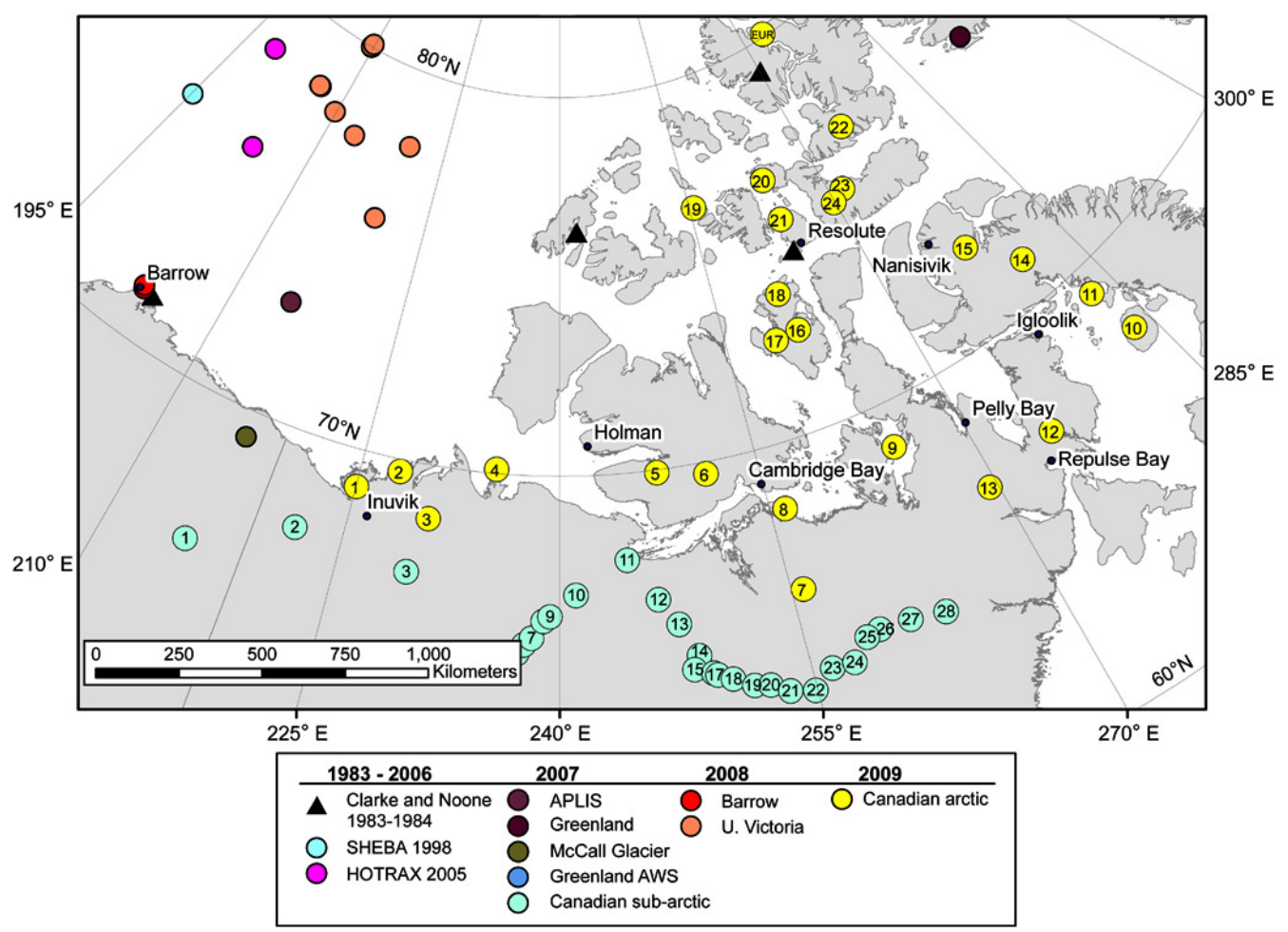

Fig. 3. Map showing sampling locations in Canada and Alaska (2007 and 2009) and vicinity. The numbering of Canadian subarctic and Canadian Arctic sites corresponds to the numbering in Table 5. 
Snow was collected by volunteers near Eureka in northern Ellesmere Island during May 2007 and during the same month on McCall Glacier, in the eastern Brooks Range of Alaska, just $100 \mathrm{~km}$ from the Arctic Ocean. Snow was sampled in April 2008 on the sea ice of Elson Lagoon, $10 \mathrm{~km}$ east of Barrow, Alaska in the normal upwind direction from town. Spectral albedo was also measured at this site and used in a comparison with aircraft measurements of the ARCTAS project (Lyapustin et al., 2010).

\subsection{Greenland (Fig. 4)}

Greenland is different from the other regions of the Arctic in that it retains a large area of snow cover through the summer. Over most of this area, but not all, the snow is melting during at least part of the summer. We therefore obtained samples in both spring and summer, with many of the summertime surface samples having experienced melt.

Professor Konrad Steffen has established an array of automatic weather stations (AWSs) at and above the 2000$\mathrm{m}$ level on the Greenland Ice Sheet (GIS) (Steffen et al., 1996; Steffen and Box, 2001). While servicing those stations in April each year, he and his coworkers collected snow samples for us.

Helicopter flights permitted sampling at two sites on the GIS in northeast Greenland in the summer of 2006 (Bøggild et al., 2010). Summertime samples were also gathered from Summit station and on the ice sheet above Thule in 2007. Sampling of three snowpits to $60-\mathrm{cm}$ depth, with vertical resolution of $1-2 \mathrm{~cm}$, was carried out in the percolation zone of the GIS at the "Raven" station (Dye-2; elevation $2316 \mathrm{~m}$ ) during the summer of 2008. The fine vertical sampling was done to study how BC is redistributed vertically during melting.

\subsection{Russia (Fig. 5)}

A collaboration of the University of Washington (UW) with the Arctic and Antarctic Research Institute (AARI) in St. Petersburg was established under the framework of the International Polar Year (IPY). The sites sampled (Fig. 5) were mostly on the tundra bordering the Arctic Ocean, or in the forest-tundra transition zone just to the south. A few sites were sampled in the subarctic larch forests near Yakutsk $\left(62^{\circ} \mathrm{N}\right)$. Commercial flights were taken in 2007 to Nar'yanMar, Vorkuta, Dikson, and Khatanga, and in 2008 to Yakutsk, Tiksi, Cherskiy, and Pevek. In each of these cities surface transport was organized to drive out $30-100 \mathrm{~km}$ away from the city, on roads, on frozen rivers, on sea ice, or crosscountry. Personnel would then walk perpendicular to the road, collecting snow at 400, 800, and $1200 \mathrm{~m}$ distance from the road. There was no significant difference among the $\mathrm{BC}$ values as a function of distance from the road, indicating that $400 \mathrm{~m}$, or even less, was adequate to avoid pollution from traffic.
There was one opportunity to take a longer overland trip, $\sim 300 \mathrm{~km}$, from Cherskiy (Yakutia) to Bilibino (Chukotka); snow samples were collected en route. There was also one opportunity to obtain samples on sea ice farther from the coast north of Tiksi, near the Laptev Polynya, with assistance from a joint German-Russian project deploying to that location by helicopter. A summary of results from the Russian expeditions and some photographs were published by Grenfell et al. (2009).

\subsection{Svalbard and Norway}

In 2007, a collaboration of UW with the Norwegian Polar Institute (NPI) was established to compare methods of measuring BC and methods of measuring spectral albedo. Surface snow was collected in March-April 2007 near the research establishment at $\mathrm{Ny}$-Ålesund, Svalbard $\left(78.9^{\circ} \mathrm{N}, 11.9^{\circ} \mathrm{E}\right)$, on tundra and on glaciers (Fig. 2). In 2009, a few samples were again collected from a glacier near $\mathrm{Ny}$-Ålesund for comparison with the NPI measurement. These samples were taken in close proximity to where snow had been collected in 1983 for CN85. Individual snowfall events were sampled from March through May 2007. In April 2007 snow samples were also collected on sea ice along the north coast of Svalbard $\left(\sim 80^{\circ} \mathrm{N}, 15^{\circ} \mathrm{E}\right)$.

Snow was collected in Spring 2008 on a mountain plateau (Fjellheisen) above the city of Troms $\emptyset$, Norway $\left(\sim 69.5^{\circ} \mathrm{N}\right.$, $\left.19.0^{\circ} \mathrm{E}\right)$ near the cable-car station. Vertical profiles were collected at $\sim 2$-day intervals in late May to examine the vertical redistribution of $\mathrm{BC}$ during melting.

\section{Results}

\subsection{Regional averages}

Of approximately 1600 snow samples collected, about 1200 are used in this study; the others were from duplicate pits or were superseded by profiles at more remote locations nearby. Regional averages of $C_{\mathrm{BC}}^{\max }, C_{\mathrm{BC}}^{\text {est }}, C_{\mathrm{BC}}^{\text {equiv }}, \AA_{\text {tot }}$ and $f_{\text {nonBC }}^{\text {est }}$ are given in Table 2. The lowest concentrations of $\mathrm{BC}$ are found in snow on the Greenland Ice Sheet with $C_{\mathrm{BC}}^{\text {est }} \sim 3 \mathrm{ng} \mathrm{g}^{-1}$, in agreement with $\mathrm{CN} 85$ and with measurements by other methods (TO and SP2) from that region (Cachier and Pertuisot, 1994; Chýlek et al., 1992, 1995; Hagler et al., 2007a, b; McConnell et al., 2007). Because of the high altitude of the Greenland sampling sites (most above $2000 \mathrm{~m}$ ), this is likely an indication of the regional free troposphere concentrations. In contrast, the Arctic Ocean samples are all taken at sea level, with $C_{\mathrm{BC}}^{\text {est }} \sim 7 \mathrm{ng} \mathrm{g}^{-1}$ basin-wide in springtime surface snow. Concentrations are lower near the North Pole than at lower latitudes (Table 3). There is an apparent gradient on the western side of the Arctic in $C_{\mathrm{BC}}^{\mathrm{est}}$ from the North Pole region $\left(\sim 5 \mathrm{ng} \mathrm{g}^{-1}\right)$ to the lower-latitude Arctic Ocean $\left(\sim 10 \mathrm{ng} \mathrm{g}^{-1}\right)$ and Arctic Alaska/Canada $\left(\sim 8 \mathrm{ng} \mathrm{g}^{-1}\right)$, then 


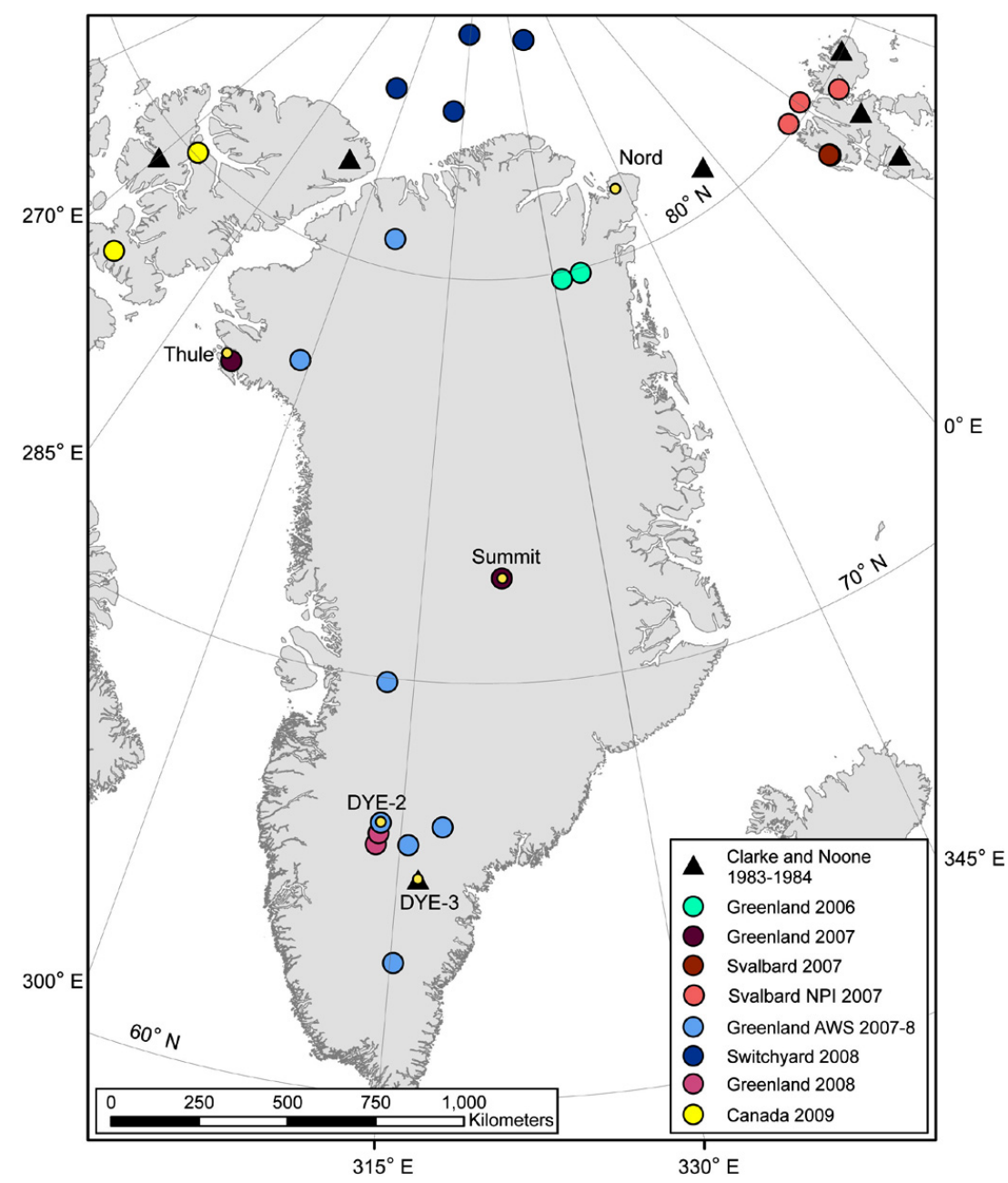

Fig. 4. Map showing sampling locations in Greenland (2006-2008) and vicinity.

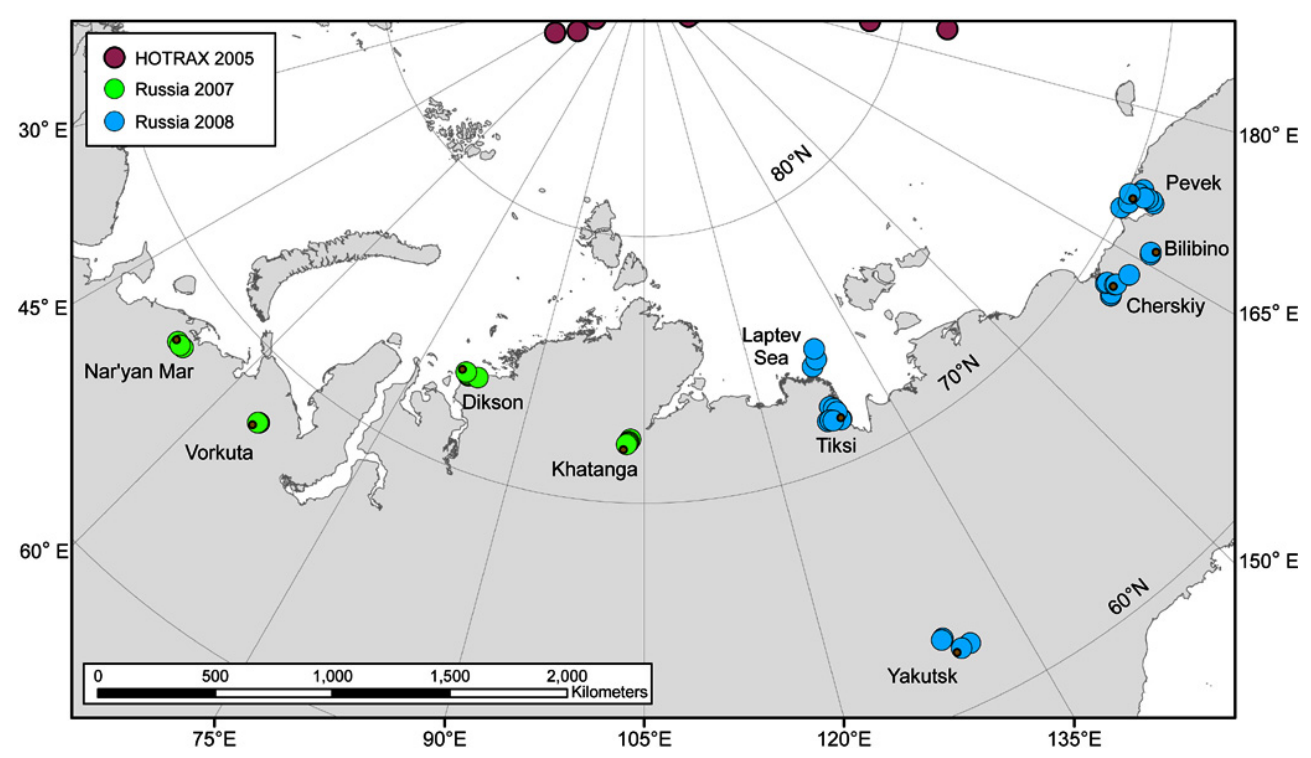

Fig. 5. Map showing sampling locations in Russia (2007 and 2008). 
Table 2. Median values for surface snow and sea ice samples within a given region; for western Russia an average is used because there are only three sites contributing to the average. Standard deviations $(1 \sigma)$ are also given where more than six values are available. Samples where surface snow had experienced melt are excluded; they are given in other tables. Data from Vorkuta are not included for Western Russia because Vorkuta is a large industrial city, and we judged the sampling locations to be insufficiently distant from the city to be regionally representative. The sea-ice samples are of the top surface of the sea ice after the snow has melted.

\begin{tabular}{llrrrrr}
\hline & & $\begin{array}{r}f_{\text {nonBC }}^{\text {est }} \\
(\%)\end{array}$ & $\AA_{\text {tot }}$ & $\begin{array}{r}C_{\mathrm{BC}}^{\text {equiv }} \\
\left(\mathrm{ng} \mathrm{g}^{-1}\right)\end{array}$ & $\begin{array}{r}C_{\mathrm{BC}}^{\text {max }} \\
\left(\mathrm{ng} \mathrm{g}^{-1}\right)\end{array}$ & $\begin{array}{r}C_{\mathrm{BC}}^{\text {est }} \\
\left(\mathrm{ng} \mathrm{g}^{-1}\right)\end{array}$ \\
\hline Snow samples & & & & & & \\
\hline Arctic Ocean, spring & median & $38 \pm 5$ & $2.1 \pm 0.2$ & $12 \pm 5$ & $9 \pm 3$ & $7 \pm 3$ \\
Arctic Ocean, summer & median & $45 \pm 6$ & $2.2 \pm 0.4$ & $14 \pm 15$ & $10 \pm 10$ & $8 \pm 8$ \\
Canadian and Alaskan Arctic & median & $45 \pm 8$ & $2.3 \pm 0.3$ & $14 \pm 7$ & $10 \pm 4$ & $8 \pm 3$ \\
Canadian sub-Arctic & median & $42 \pm 6$ & $2.2 \pm 0.2$ & $20 \pm 12$ & $15 \pm 9$ & $14 \pm 9$ \\
Greenland, spring & median & $51 \pm 6$ & $2.5 \pm 0.2$ & $7 \pm 3$ & $5 \pm 2$ & $4 \pm 2$ \\
Greenland, summer & median & $47 \pm 14$ & $2.5 \pm 0.6$ & $3 \pm 3$ & $2 \pm 2$ & $1 \pm 1$ \\
western Russia & average & 25 & 1.6 & 34 & 30 & 27 \\
eastern Russia & median & $46 \pm 8$ & $2.4 \pm 0.4$ & $48 \pm 90$ & $39 \pm 59$ & $34 \pm 46$ \\
Svalbard & average & 44 & 2.3 & 87 & 61 & 48 \\
Troms $\varnothing$, Norway & median & $26 \pm 10$ & $1.7 \pm 0.4$ & $18 \pm 12$ & $14 \pm 10$ & $13 \pm 9$ \\
\hline Sea ice samples & median & $26 \pm 9$ & $1.6 \pm 0.4$ & $29 \pm 16$ & $24 \pm 14$ & $21 \pm 12$ \\
\hline Arctic Ocean, summer & & & & & & $7 \pm 7$ \\
\hline
\end{tabular}

down to sub-Arctic Canada $\left(14 \mathrm{ng} \mathrm{g}^{-1}\right)$. The eastern Arctic sites at similar latitudes to the Canadian Arctic have approximately double the concentrations $\left(21,27\right.$ and $34 \mathrm{ng} \mathrm{g}^{-1}$, respectively for Troms $\varnothing$, West Russia and East Russia). Svalbard, also in the eastern Arctic but farther north $\left(\sim 80^{\circ} \mathrm{N}\right)$ has a median concentration of $13 \mathrm{ng} \mathrm{g}^{-1}$, as compared to $8 \mathrm{ng} \mathrm{g}^{-1}$ in Arctic Canada, which spans $\sim 70-78^{\circ} \mathrm{N}$. This suggests that sources in northern Russia and northern Europe play a stronger role in reducing Arctic snow albedo than do sources in North America, consistent with what is predicted by models (e.g. Flanner et al., 2007, 2009; Koch et al., 2009).

The estimated BC concentrations are also more variable in the eastern Arctic (relative standard deviations 60\%, 66\% and $115 \%$ for Troms $\varnothing$, Svalbard and E. Russia respectively) and in the Canadian sub-Arctic (64\%) than for the Canadian/Alaskan Arctic (39\%) and Arctic Ocean (38\%). This likely reflects a closer proximity to sources. The relatively high variability in $C_{\mathrm{BC}}^{\mathrm{est}}$ for Greenland (50\% spring; $100 \%$ summer) may be due in part to measurement uncertainty, but our analysis indicates that this accounts for $<10 \%$ of the variability (Grenfell et al., 2010). More likely, especially for the summertime data, variations in deposition and/or insnow processes (undetected melt; sublimation) are playing a large role.

The variations discussed above reflect the spatial variability of concentrations within these sometimes very large regions (Figs. 2-5). As a test of individual snow samples' representativeness of a given sampling location, in Fig. 6 we compare side-by-side samples that were separated horizon-

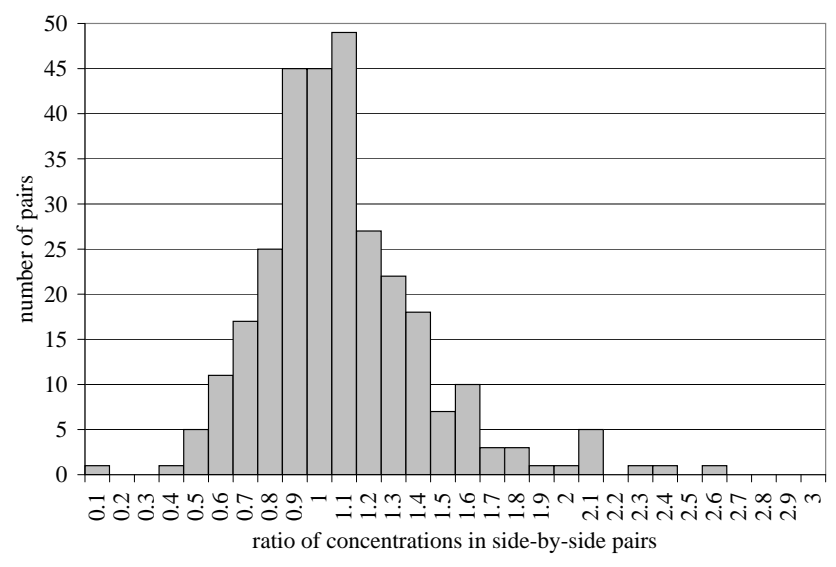

Fig. 6. Side-by-side samples were taken at the surface and throughout the vertical column for the sampling sites in East and West Russia, the Canadian Arctic and at Troms $\varnothing$, Norway. Shown is a histogram of the left/right ratios of $C_{\mathrm{BC}}^{\text {est }}$ for paired samples. The average $1-\sigma$ spread in the ratios was \pm 0.27 for Troms $\varnothing, \pm 0.34$ for the Canadian Arctic and \pm 0.42 for Russia.

tally by $50-100 \mathrm{~cm}$. The two are almost always within $50 \%$ of one another and typically are within $20-30 \%$ of each other. The largest differences are found in snowpits with strong vertical gradients in $\mathrm{BC}$ concentration, so that vertical variations caused apparent horizontal variations due to imperfect vertical coincidence of the two samples at the same level. (This mismatch can be caused by wind-scouring on the scale of 
Table 3. Median values for snow samples from the Arctic Ocean, segregated by sampling region (Fig. 2), season and snow type.

\begin{tabular}{|c|c|c|c|c|c|c|c|}
\hline Year & $\begin{array}{r}f_{\text {nonBC }}^{\text {est }} \\
(\%)\end{array}$ & $\AA_{\text {tot }}$ & $\begin{array}{c}C_{\mathrm{BC}}^{\text {equiv }} \\
\left(\operatorname{ng~g}^{-1}\right)\end{array}$ & $\begin{array}{c}C_{\mathrm{BC}}^{\max } \\
\left(\operatorname{ngg}^{-1}\right)\end{array}$ & $\begin{array}{r}C_{\mathrm{BC}}^{\mathrm{est}} \\
\left(\mathrm{ng} \mathrm{g}^{-1}\right)\end{array}$ & $\begin{array}{r}\# \\
\text { samp. }\end{array}$ & $\begin{array}{l}\text { Field } \\
\text { Campaign }\end{array}$ \\
\hline \multicolumn{8}{|c|}{ Central Arctic } \\
\hline \multicolumn{8}{|c|}{ April/May: aged surface snow } \\
\hline 2006 & 33 & 1.9 & 10 & 8 & 7 & 2 & NPEO \\
\hline 2007 & 45 & 2.3 & 6 & 4 & 3 & 7 & NPEO/NW Passage \\
\hline 2008 & 36 & 2.0 & 9 & 7 & 6 & 4 & Switchyard \\
\hline \multicolumn{8}{|c|}{ September: new snow } \\
\hline 2005 & 47 & 2.2 & 6 & 4 & 3 & 2 & HOTRAX \\
\hline \multicolumn{8}{|c|}{ September: aged surface snow } \\
\hline 2005 & 43 & 2.2 & 9 & 7 & 5 & 6 & HOTRAX \\
\hline \multicolumn{8}{|c|}{ September: windpack snow } \\
\hline 2005 & 38 & 1.9 & 25 & 18 & 15 & 3 & HOTRAX \\
\hline \multicolumn{8}{|c|}{ Canadian Basin $80^{\circ}-88^{\circ} \mathrm{N}$} \\
\hline \multicolumn{8}{|c|}{ August/September: new snow } \\
\hline 2005,2008 & 52 & 2.4 & 6 & 4 & 3 & 9 & HOTRAX/U. Vic \\
\hline \multicolumn{8}{|c|}{ August: "aged surface snow" (sea ice?) } \\
\hline 2005 & 44 & 2.2 & 15 & 11 & 9 & 9 & HOTRAX \\
\hline \multicolumn{8}{|c|}{ August-September: "windpack snow” (sea ice?) } \\
\hline 2005,2008 & 46 & 2.2 & 36 & 25 & 20 & 6 & HOTRAX/U. Vic \\
\hline \multicolumn{8}{|c|}{ North of Greenland } \\
\hline \multicolumn{8}{|c|}{ late April/early May: aged surface snow } \\
\hline 2008 & 43 & 2.3 & 14 & 10 & 8 & 2 & Switchyard \\
\hline 2008 & 49 & 2.5 & 11 & 8 & 6 & 2 & Switchyard \\
\hline \multicolumn{8}{|c|}{ Canadian Basin $74^{\circ}-80^{\circ} \mathrm{N}$} \\
\hline \multicolumn{8}{|c|}{ April: aged surface snow } \\
\hline 2007 & 39 & 2.1 & 20 & 14 & 12 & 5 & APLIS \\
\hline \multicolumn{8}{|c|}{ April: windpack snow } \\
\hline 2007 & 38 & 2.0 & 19 & 14 & 12 & 6 & APLIS \\
\hline \multicolumn{8}{|c|}{ April: sub-surface snow } \\
\hline 2007 & 36 & 1.9 & 12 & 9 & 8 & 4 & APLIS \\
\hline \multicolumn{8}{|c|}{ April: average over full snowpack depth } \\
\hline 1998 & 45 & 2.2 & 11 & 8 & 7 & 39 & SHEBA \\
\hline \multicolumn{8}{|c|}{ May: average over full snowpack depth } \\
\hline 1998 & 39 & 2.0 & 15 & 11 & 9 & 27 & SHEBA \\
\hline \multicolumn{8}{|c|}{ August: new snow } \\
\hline 2008 & 29 & 1.3 & 9 & 8 & 6 & 2 & U. Vic \\
\hline \multicolumn{8}{|c|}{ August: "aged surface snow" (sea ice?) } \\
\hline 2008 & 46 & 2.3 & 31 & 21 & 16 & 5 & U. Vic \\
\hline \multicolumn{8}{|c|}{ August: "aged sub-surface snow" (sea ice?) } \\
\hline 2008 & 48 & 2.0 & 15 & 10 & 8 & 5 & U. Vic \\
\hline \multicolumn{8}{|c|}{ August: “windpack snow” (sea ice?) } \\
\hline 2008 & 53 & 2.6 & 55 & 36 & 26 & 1 & U. Vic \\
\hline
\end{tabular}


the horizontal separation of the samples). The distribution of ratios for the surface pairs only (not shown) is nearly identical to that shown in Fig. 6 for all side-by-side pairs. Thus, it appears that there are variations in snow BC concentrations at the meter scale horizontally which, in some locations, are of the same order as the regional-scale variability in concentrations (20-30\% vs. 30-60\%). This emphasizes the importance of gathering multiple samples from both a given sampling location and a given region in order to obtain representative concentration values. By comparison, the mean absolute difference in $\AA_{\text {tot }}$ for side-by-side pairs was only 0.11 , much less than the variability in $\AA_{\text {tot }}$ within a given region (Fig. 7). This implies that, in contrast to the concentrations, the aerosol type is essentially invariant at the small (meters) scale.

At all locations $\AA_{\text {tot }}(450-600 \mathrm{~nm})$ always exceeds 1.0 (Fig. 7, Table 2) and, for the regionally-averaged surface snow samples, $20 \%-50 \%$ of spectrally integrated light absorption is due to species other than BC (Table 2). In particular, the non-BC constituents dominate light absorption at wavelengths $300-500 \mathrm{~nm}$, especially for aerosol with high $\AA_{\text {tot }}$ (Fig. 1). Our photometric measurements extend down only to $420 \mathrm{~nm}$, so we extrapolate the absorption optical depth linearly from $420 \mathrm{~nm}$ down to $300 \mathrm{~nm}$ (as well as from $700 \mathrm{~nm}$ up to $750 \mathrm{~nm}$ ) in order to capture the spectral range where absorption of solar radiation by impurities in the snowpack is significant (Grenfell et al., 2010). This makes $f_{\text {nonBC }}^{\text {est }}$ and $C_{\mathrm{BC}}^{\text {equiv }}$ the most uncertain of our derived quantities, all of the rest of which depend only on the measured absorption values between 420 and $700 \mathrm{~nm}$. Regardless, it is clear that in order to accurately calculate the radiative forcing of light-absorbing aerosol in Arctic snow one must accurately represent not only black carbon concentrations and optical properties but also the concentrations and optical properties of "brown" (light-absorbing) organic carbon and/or soil dust. This presents a challenge, as studies to date have found a wide range of spectral absorption properties for both brown carbon and soil dust (e.g. Kirchstetter et al., 2004; Lafon et al., 2006; Linke et al., 2006; Hoffer et al., 2006; Bergstrom et al., 2007; Clarke et al., 2007; Sun et al., 2007).

Generally, urban and industrial fossil fuel emissions have absorption Ångstrom exponents of 1.0-1.5 (Millikan, 1961; Rosen et al., 1978; Bergstrom et al., 2007). However, this can vary depending on the material being burned, the burn temperature and other conditions, so $\AA$ can be $>2$ for aerosol from, e.g., inefficient coal burning (Bond et al., 1999; Bond, 2001). The wavelength-dependence of biomass burning aerosol is even more variable than for fossil fuel aerosol, but in general it tends to be higher, with measured values as low as 1.1 but most falling in the 1.5-2.5 range (Kirchstetter et al., 2004; Bergstrom et al., 2007; Clarke et al., 2007). The spectral absorption properties of dust are even more poorly constrained than for biomass burning but are also higher than for fossil fuel emissions ( $2<\AA<5$; Fialho et al., 2005; La- (a)

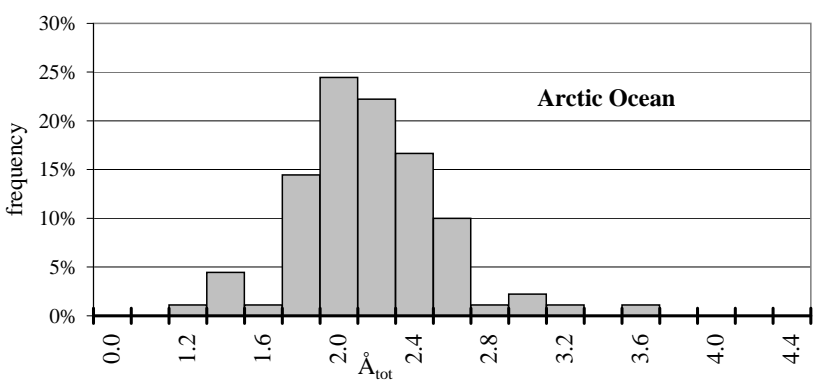

(b)
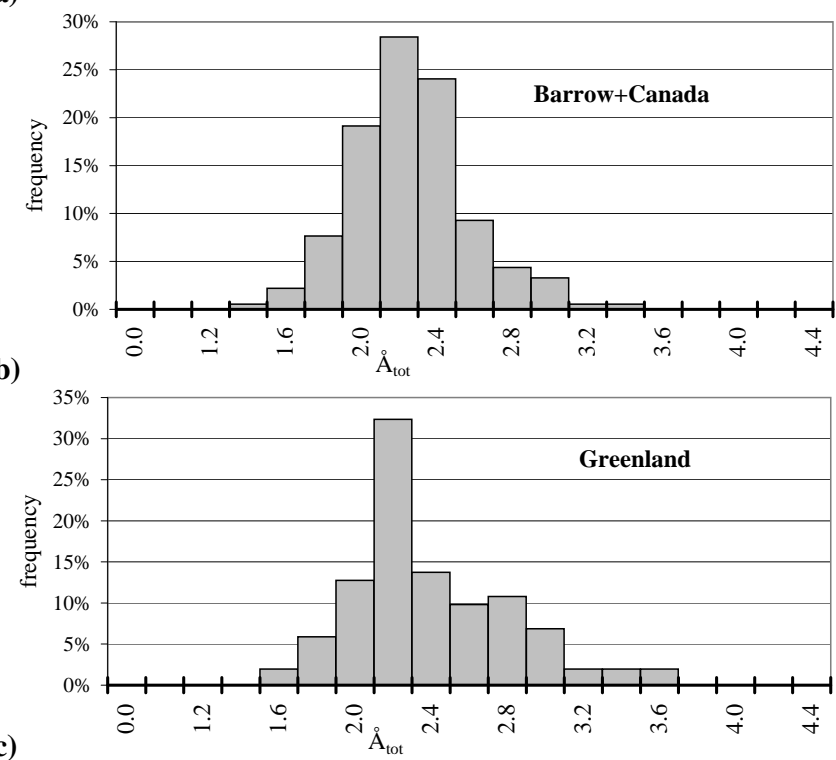

(c)

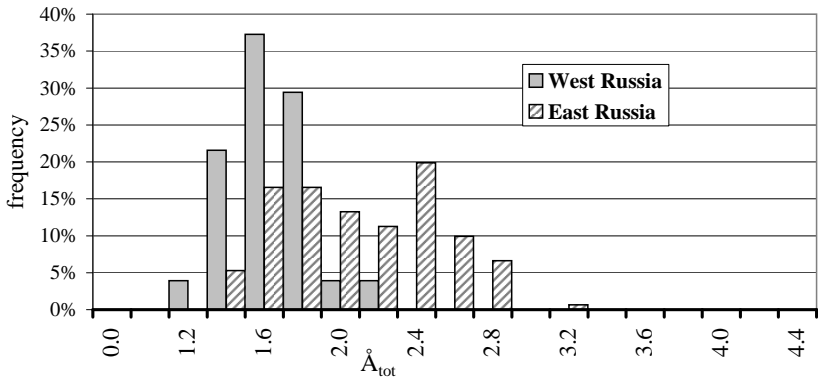

(d)

(e)

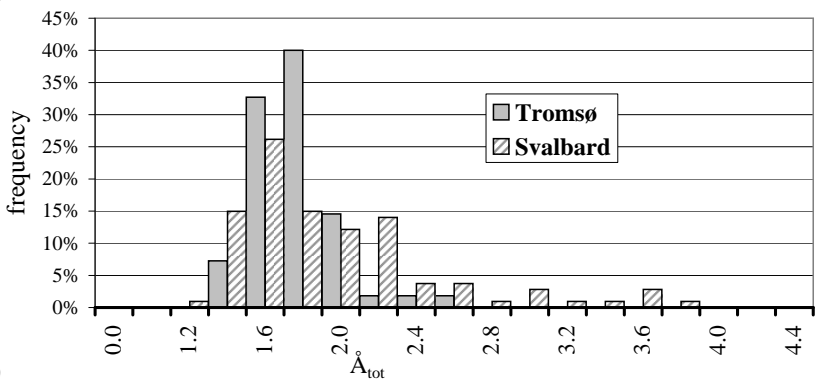

Fig. 7. Histograms of the frequency of occurrence of the absorption Ångstrom exponent $\AA_{\text {tot }}(450-600 \mathrm{~nm})$ within different sampling regions. Samples from all snow depths are included.

fon et al., 2006; Linke et al., 2006; Meloni et al., 2006; Bergstrom et al., 2007; Müller et al., 2009). Thus, $\AA_{\text {tot }}$ can not be used definitively to separate fossil-fuel vs. biomass burning or dust as the source of light-absorbing material in 
snow, but generally we expect lower values for samples more heavily influenced by fossil-fuel burning and higher values where biomass burning or dust plays a larger role.

In collecting snow samples in the field we observed that dust was common in the snow in parts of the Arctic where the snow is so thin that not all the ground is covered. In gathering samples we tried to avoid obviously soil/dust-laden snow, and as shown by Hegg et al. $(2009,2010)$ many of our filters are brown not because the snow contains soil dust but rather because it contains organic carbon.

The relatively lower absorption Ångstrom exponents $\left(\AA_{\text {tot }} \sim 1.6-1.7\right.$; Table 2 and Fig. 7$)$ for Svalbard, Troms $\varnothing$, and Western Russia suggest that the former sites are more heavily influenced by fossil-fuel pollution, whereas the values of $\AA_{\text {tot }}$ from surface snow in Greenland (2.5) and the Canadian/Alaskan Arctic (2.3) are more consistent with biomass burning pollution or dust. Intermediate values are found in Eastern Russia, the Canadian sub-Arctic and summertime Arctic ocean ( 2.2), and in the springtime Arctic $(\sim 2.1)$, suggesting they are influenced by a mix of sources. Hegg et al. $(2009,2010)$ chemically analyzed the meltwater and filters from a subset of the snow samples from the Arctic Ocean, Greenland, Canada, and Eastern and Western Russia that are photometrically analyzed here, then performed a source-attribution study using positive matrix factorization (PMF) analysis. They found that, in all of these locations except the Arctic Ocean, biomass burning was the dominant source of light-absorbing aerosol in the snow, whereas in the Arctic Ocean the dominant source was industrial pollution. Based on this we would expect the Arctic Ocean values of $\AA_{\text {tot }}$ to be systematically lower than for Greenland, Canada or Russia. While this is not apparent (Table 2 and Fig. 7), Hegg et al. (2009, 2010) were studying the source of BC and non-BC LAA in the snow, so sources associated with higher concentrations are given more weight. Further, in the Hegg et al. $(2009,2010)$ studies, the only samples analyzed from the Arctic Ocean were from near the North Pole ("Central Arctic April/May aged surface snow" in Table 3). In this region, the higher values of $\AA_{\text {tot }}$ (2.3) are associated with low concentrations of $\mathrm{BC}\left(C_{\mathrm{BC}}^{\mathrm{est}}<3 \mathrm{ng} \mathrm{g}^{-1}\right)$, whereas $\AA_{\text {tot }}$ is $\leq 2.0$ for the higher-concentration samples $\left(6-7 \mathrm{ng} \mathrm{g}^{-1}\right)$ samples, so the concentration-weighted median $\AA_{\text {tot }}$ would be lower than that given in Table 2. In both eastern and western Russia Hegg et al. $(2009,2010)$ found that most of the BC was from biomass burning, but in western Russia there was also a significant contribution from pollution (Hegg et al., 2009) which did not show up in the eastern Russia samples (Hegg et al., 2010), consistent with the lower values of $\AA_{\text {tot }}$ in western than in eastern Russia. Hegg et al. (2009, 2010) have not yet done a source attribution analysis for the samples from Troms $\varnothing$ or Svalbard where the values of $\AA_{\text {tot }}$ are low. Thus it would be beneficial to expand the source-attribution study to include samples from these and other sites in the European sector of the Arctic.
In addition to the springtime Arctic Ocean snow samples, we also have measurements of bare melting sea ice from two summertime ship-based campaigns (HOTRAX and U. Vic). In summer the sea ice is wet and melting, and the surface of drained melting sea ice is a decomposed granular layer several centimeters thick which resembles coarse-grained snow (median grain radius $\sim 2 \mathrm{~mm}$ ) (Perovich et al., 2002). New snowfall also occasionally occurs in summer. Therefore interpretation of these results is more complicated than for the spring samples, and there is the possibility that some were incorrectly categorized, e.g. as aged snow when in fact they were melting sea ice. The estimated BC concentrations for the summertime sea ice are, on average, very similar to those for both spring and summer snow, and like the summer snow are highly variable. The absorption Ångstrom exponent is also somewhat higher in the summer sea ice than in springtime snow, possibly attributable to more silt in the sea-ice samples than in the snow samples. Further discussion is given below, where we look in more detail at the results within each region.

The range of values shown in Table 2, $2-50 \mathrm{ng} \mathrm{g}^{-1}$, is intermediate between those of Antarctic snow (0.2$0.6 \mathrm{ng} \mathrm{g}^{-1}$; Warren and Clarke, 1990; Grenfell et al., 1994) and those of midlatitude industrial regions $\left(50-1000 \mathrm{ng} \mathrm{g}^{-1}\right.$; Huang et al., 2011).

\subsection{Results by region}

While the regional averages given in Table 2 are useful for getting a sense of Arctic-wide concentrations of lightabsorbing aerosol in the snow, a detailed analysis of the data within a given region is necessary for rigorous testing against models and for insight into the variations in concentration and LAA type. These are given in separate tables for the Arctic Ocean, Canada and Alaska, Greenland, Russia, and Norway and Svalbard.

\subsubsection{Arctic Ocean}

We have both spring and summer samples for the Arctic Ocean region, with the summertime samples including both snow and melting ice. We separately analyze the snow samples (Table 3) and the sea ice samples (Table 4), grouping the snow samples into four geographic sub-regions (Fig. 2, Table 3). We caution that summertime samples collected by volunteers may have been misclassified as aged snow rather than melting sea ice, because the two can appear nearly indistinguishable.

Newly fallen snow samples from August and September in the central Arctic and Canadian Basin have lower concentrations (average $C_{\mathrm{BC}}^{\text {est }} 4 \mathrm{ng} \mathrm{g}^{-1}$ ) than does most aged snow in both spring and summer. Wind-packed snow has the highest concentrations, with $C_{\mathrm{BC}}^{\text {est }}$ of $15 \mathrm{ng} \mathrm{g}^{-1}$ in spring and $20 \mathrm{ng} \mathrm{g}^{-1}$ in autumn, though the value of $26 \mathrm{ng} \mathrm{g}^{-1}$ for summertime "windpacked snow" may be a case of misidentification of sea ice as snow. 
Table 4. Values for bare sea ice samples from the Arctic Ocean in summer. There is one sample per measurement shown.

\begin{tabular}{|c|c|c|c|c|c|c|c|c|}
\hline Year & Lat $N$ & Lon $\mathrm{E}$ & $\begin{array}{r}f_{\text {nonBC }}^{\text {est }} \\
(\%)\end{array}$ & $\AA_{\text {tot }}$ & $\begin{array}{c}C_{\mathrm{BC}}^{\text {equiv }} \\
\left(\operatorname{ng~g}^{-1}\right)\end{array}$ & $\begin{array}{r}C_{\mathrm{BC}}^{\max } \\
\left(\mathrm{ng} \mathrm{g}^{-1}\right)\end{array}$ & $\begin{array}{r}C_{\mathrm{BC}}^{\mathrm{est}} \\
\left(\mathrm{ng} \mathrm{g}^{-1}\right)\end{array}$ & $\begin{array}{r}\text { sample depth } \\
(\mathrm{cm})\end{array}$ \\
\hline \multicolumn{9}{|c|}{ Bare first-year sea ice } \\
\hline 2005 & 76.035 & 202.070 & 44 & 2.1 & 8 & 6 & 5 & surface \\
\hline 2005 & 78.439 & 197.321 & 43 & 2.1 & 7 & 5 & 4 & surface \\
\hline 2005 & 78.291 & 183.321 & 49 & 2.3 & 7 & 5 & 4 & surface \\
\hline \multicolumn{9}{|c|}{ Melting sea ice } \\
\hline 2005 & 87.660 & 150.902 & 57 & 2.7 & 67 & 37 & 23 & surface \\
\hline 2008 & 78.000 & 220.420 & 37 & 1.9 & 24 & 18 & 15 & $0-2$ \\
\hline 2008 & 78.000 & 220.420 & 39 & 2.0 & 15 & 11 & 9 & $2-8$ \\
\hline \multicolumn{9}{|c|}{ Sea ice cores } \\
\hline \multirow{4}{*}{2005} & \multirow{4}{*}{78.439} & \multirow{4}{*}{197.321} & 53 & 2.4 & 11 & 7 & 5 & $0-7.5$ \\
\hline & & & 57 & 2.6 & 8 & 5 & 3 & $7.5-15$ \\
\hline & & & 50 & 2.3 & 9 & 6 & 5 & $15-22.5$ \\
\hline & & & 64 & 2.9 & 11 & 6 & 4 & $22.5-30$ \\
\hline \multirow{4}{*}{2005} & \multirow{4}{*}{87.660} & \multirow{4}{*}{150.902} & 60 & 2.8 & 37 & 22 & 15 & $0-6$ \\
\hline & & & 61 & 2.8 & 24 & 14 & 10 & $6-12$ \\
\hline & & & 53 & 2.5 & 38 & 24 & 18 & $12-18$ \\
\hline & & & 51 & 2.5 & 61 & 38 & 30 & $18-24$ \\
\hline \multirow{4}{*}{2005} & \multirow{4}{*}{88.456} & \multirow{4}{*}{213.468} & 52 & 2.4 & 15 & 9 & 7 & $0-7$ \\
\hline & & & 51 & 2.3 & 8 & 5 & 4 & $7-14$ \\
\hline & & & 44 & 1.9 & 4 & 3 & 2 & $14-21$ \\
\hline & & & 47 & 2.2 & 9 & 6 & 5 & $21-28$ \\
\hline
\end{tabular}

The higher concentrations in aged snow may be the result of concentration by sublimation, or by dry depositional processes. They could also result from a mis-assignment of dustabsorption to BC-absorption, and this may be particularly a factor for the wind-packed snow which is more likely to contain dust. A high-bias in $C_{\mathrm{BC}}^{\text {est }}$ could result if the Ångstrom exponent of dust (or other non-BC LAA) is less than 5.0, in which case we would be interpreting light absorption by the non-BC LAA as being due to BC. At present we cannot distinguish these two possibilities. We doubt that sedimentladen sea ice is a significant source of dust for the snow, because the sediment is not exposed at the surface until after the snow melts, and thereafter it is wetted by the melting sea ice so could not be lifted by wind. The sediment also melts into the ice, forming cryoconite holes several tens of $\mathrm{cm}$ below the ice surface.

Three samples from bare first-year sea ice in the southern Canadian Basin (first three entries in Table 4) had BC concentrations similar to those of newly fallen snow (4$5 \mathrm{ng} \mathrm{g}^{-1}$ ). Melting sea ice had considerably higher concentrations (9-23 $\mathrm{ng} \mathrm{g}^{-1}$ ), consistent with the consolidation of BC due to incomplete washout with melt. Three sea ice "cores" from the Canadian Basin show no apparent trend with latitude, though there is some indication of $\mathrm{BC}$ enhancement at the ice surface vs. just below the surface, again consistent with retention of $\mathrm{BC}$ (or sediment) at the surface during melt.

The complexity of these samples and their interpretation highlights a difficulty in determining how much $\mathrm{BC}$ from combustion aerosol is lowering Arctic snow and sea ice albedo. Clearly, one must know more than the deposition rate of $\mathrm{BC}$ to the surface. Also important are understanding post-depositional processes that occur in the snow and seaice that can alter $\mathrm{BC}$ concentrations, and knowing whether sediment is also present in sufficient concentrations to significantly reduce snow/ice albedo. In summer there is the added complication that there is a mix of aged snow, melting snow, melting sea ice, and occasionally new snow, all of which have different grain sizes and therefore different albedo reductions for a given BC concentration (Fig. 7 of Warren and Wiscombe, 1980).

\subsubsection{Canada and Alaska}

The most striking aspect of the Canadian and Alaskan Arctic data set (Table 5) is the uniformity in the data across a broad geographic area. The 2009 data set spans $60^{\circ}$ of longitude and $\sim 10^{\circ}$ of latitude (Fig. 3), including snow on tundra, small ice caps, frozen lakes, and sea ice (Fig. 8), but the standard 
deviation of $\mathrm{BC}$ concentrations in surface snow is only $38 \%$. For this field campaign, samples were taken from throughout the snowpack depth (typically 5-7 sample depths) from the top of the snowpack down to the ground or ice surface, a total of 306 samples. Ignoring the lowermost samples because of possible contamination by soil or sea-ice algae, 256 samples remained for analysis. On the assumption that the seasonality of the snowfall was similar across the whole region, we plot data from all 24 profiles together versus the fraction of total snowpack depth (Fig. 9) to look for seasonal changes in concentrations and type of LAA. These profiles show a decrease in $C_{\mathrm{BC}}^{\text {est }}$ from $\sim 8 \mathrm{ng} \mathrm{g}^{-1}$ at the surface, corresponding to April snowfall, to $\sim 5 \mathrm{ng} \mathrm{g}^{-1}$ for early winter snow (lowest $30 \%$ of snowpack). There are occasional excursions to higher values in the bottom $40 \%$ of the snowpacks. This is snow from when total snowpack depth was $\sim 5-20 \mathrm{~cm}$, so it is possible that windblown soil is biasing these results, if we are not accurately distinguishing the contributions to light absorption by BC vs. soil dust. This increase in deposition of $\mathrm{BC}$ to the snowpack moving from winter into spring is consistent with an increase in agricultural burning as the snow melts at lower latitudes. It could also be due to an increased efficiency of transport of pollution into the region with the change of seasons, or to a combination of the two. There is some indication of a slight increase in $f_{\text {nonBC }}^{\text {est }}$ in the middle of the snowpack (Fig. 9), but generally it varies between $30 \%$ and 50\% throughout the snowpack depth. These combined results point to a common source type for $\mathrm{BC}$ through both winter and spring.

Hegg et al. (2010) carried out a corresponding chemical analysis in which they concluded that almost all the BC was associated with burning of crops and grasslands throughout the snowpack depth. The absorption Ångstrom exponents, $\AA_{\text {tot }}$, shown in Table 5 are consistent with this finding, which applied across all but two regions: Sites 1-3 near Inuvik (Fig. 3) had a prominent boreal biomass source signature in autumn and early winter; these are the only sites of the expedition that were located within the boreal forest. Sites 19-21, near the tailings of an abandoned metals mine on Little Cornwallis Island, showed BC in the sub-surface snow layers to be approximately equally attributable to crop/grassland burning and pollution.

In addition to the 2009 Canadian Arctic survey we also have a springtime surface snow sample from northern Ellesmere Island in 2007 (Eureka, EUR) and samples from two sites on the north slope of Alaska in 2008: Barrow (BRW) and the McCall Glacier (MCG) (Fig. 2; Table 5). The concentrations, $\AA_{\text {tot }}$ and $f_{\text {nonBC }}^{\text {est }}$ from these sites fit well within the range of values from our 2009 data.

The BC content of the Canadian subarctic samples from 2007 is systematically higher than that of the Canadian Arctic samples, at $\sim 14 \mathrm{ng} \mathrm{g}^{-1}$, and also shows greater variability, exhibiting a standard deviation of $9 \mathrm{ng} \mathrm{g}^{-1}$, compared to $3 \mathrm{ng} \mathrm{g}^{-1}$ for the Arctic samples (Table 2).

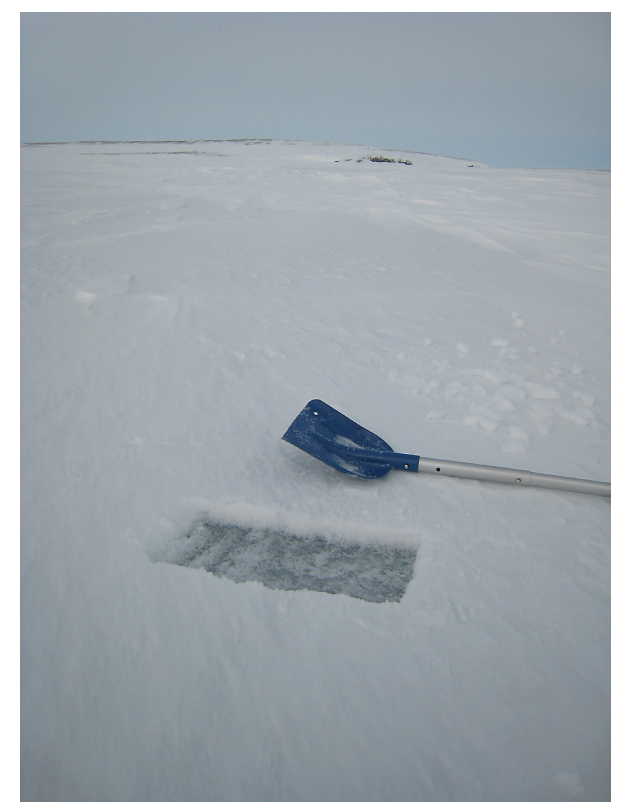

Fig. 8. Thin snow on sea ice in the Canadian Arctic, Site 4, near Cape Parry $\left(70^{\circ} \mathrm{N}, 125^{\circ} \mathrm{W}\right)$.

\subsubsection{Greenland}

The Greenland data are a mix of samples from spring (all Automated Weather Station, AWS, sites) and summer (KPCL, Summit, Thule and Dye-2); we display data for these two seasons separately in Table 6. The summertime snow appears to be cleaner than the springtime snow (median $C_{\mathrm{BC}}^{\text {est }}$ $1.7 \mathrm{ng} \mathrm{g}^{-1}$ vs. $3.5 \mathrm{ng} \mathrm{g}^{-1}$ ), but these sample sets are from different locations so this could reflect spatial rather than seasonal variations. However, vertical profiles from the Dye2 station (Fig. 10) afford an opportunity to see how LAA changes from spring to summer. Dye-2 is in the "percolation zone" of southern Greenland. In a typical year about $1 \mathrm{~m}$ of snow falls in winter and spring, with density $\sim 300 \mathrm{~kg} \mathrm{~m}^{-3}$. During July about half of that accumulation melts, but the meltwater refreezes in the cold snow below. We obtained vertical profiles on 25 July 2008, just after a snowfall event had deposited $7 \mathrm{~cm}$ of new snow on top of the melting snow. Three snowpits were sampled, at distances 5, 30, and $60 \mathrm{~km}$ from the station, in the normal upwind direction (south). The $30-\mathrm{km}$ profile showed no higher BC concentrations than the $60-\mathrm{km}$ profile, indicating that they were not influenced by pollution from the station. The snow was sampled down to $60 \mathrm{~cm}$ depth, which probably includes nearly the full depth of the 2007-2008 accumulation season; the buried surfacemelt layer from the summer of 2007 is probably located just below the bottom of the snowpit.

Two features are apparent in Fig. 10. First, the concentrations are dramatically higher in the melt layer (centered $\sim 10 \mathrm{~cm}$ depth), which had been at the surface for several weeks, than for the new snow or for the deeper snow (below 
Table 5. Median values from the Canadian sub-Arctic (2007) and the Canadian (2009) and Alaskan (2007, 2008) Arctic. The 2009 sample sites are numbered, as given in Fig. 3; a 2007 sample from Eureka, Canada (EUR) and samples from Barrow (BRW) and McCall Glacier, Alaska (MCG) are included in the Arctic data set. For the sub-Arctic samples, surface samples are of the top $1 \mathrm{~cm}$ of the snow, and the depth-integrated samples are of the top $20 \mathrm{~cm}$ of the snow. For the Canadian Arctic, surface samples are typically from the top 1-3 cm of the snow and the sub-surface samples from all depths below this, excluding the lowest sample in order to avoid contamination by surface soil or sea-ice algae. For the Arctic Canada sites 1-24, duplicate samples were taken at each level; the average of the pair is considered a single sample in this table. The sub-arctic samples are all from the snowmobile traverse of Sturm et al. (2008).

\begin{tabular}{|c|c|c|c|c|c|c|c|c|c|c|c|}
\hline Site & Lat $\mathrm{N}$ & Lon E & $\begin{array}{r}\text { snow } \\
\text { depth } \\
(\mathrm{cm})\end{array}$ & & $\begin{array}{r}f_{\text {nonBC }}^{\text {est }} \\
(\%)\end{array}$ & $\AA_{\text {tot }}$ & $\begin{array}{c}C_{\mathrm{BC}}^{\text {equiv }} \\
\left(\operatorname{ng~g}^{-1}\right)\end{array}$ & $\begin{array}{r}C_{\mathrm{BC}}^{\max } \\
\left(\operatorname{ng~g}^{-1}\right)\end{array}$ & $\begin{array}{r}C_{\mathrm{BC}}^{\mathrm{est}} \\
\left(\operatorname{ng~g}^{-1}\right)\end{array}$ & $\begin{array}{r}\text { surface: } \\
\text { sub-surf } \\
C_{\mathrm{BC}}^{\mathrm{est}}\end{array}$ & $\begin{array}{r}\# \\
\text { samp. }\end{array}$ \\
\hline \multicolumn{12}{|c|}{ Canadian and Alaskan Arctic } \\
\hline \multirow[t]{2}{*}{1} & 68.986 & 224.938 & 38 & surface & 45 & 2.3 & 11 & 8 & 6 & \multirow[b]{2}{*}{0.6} & 1 \\
\hline & & & & sub-surface & 47 & 2.8 & 18 & 12 & 10 & & 5 \\
\hline \multirow[t]{2}{*}{2} & 69.635 & 227.819 & 33 & surface & 43 & 2.2 & 17 & 12 & 10 & \multirow{2}{*}{1.1} & 1 \\
\hline & & & & sub-surface & 44 & 2.3 & 17 & 12 & 9 & & 4 \\
\hline \multirow[t]{2}{*}{3} & 68.568 & 230.477 & 29 & surface & 34 & 1.9 & 12 & 10 & 8 & \multirow{2}{*}{1.3} & 1 \\
\hline & & & & sub-surface & 42 & 2.2 & 11 & 8 & 6 & & 4 \\
\hline \multirow[t]{2}{*}{4} & 70.067 & 235.027 & 21 & surface & 56 & 2.7 & 20 & 13 & 9 & \multirow{2}{*}{0.8} & 3 \\
\hline & & & & sub-surface & 54 & 2.6 & 26 & 16 & 12 & & 3 \\
\hline \multirow[t]{2}{*}{5} & 69.895 & 247.253 & 20 & surface & 40 & 2.1 & 11 & 8 & 7 & \multirow{2}{*}{0.4} & 2 \\
\hline & & & & sub-surface & 55 & 2.8 & 34 & 21 & 15 & & 2 \\
\hline \multirow[t]{2}{*}{6} & 69.663 & 250.904 & 27 & surface & 39 & 2.1 & 10 & 7 & 6 & \multirow{2}{*}{1.3} & 1 \\
\hline & & & & sub-surface & 44 & 2.3 & 8 & 6 & 5 & & 4 \\
\hline \multirow[t]{2}{*}{7} & 66.171 & 255.626 & 30 & surface & 38 & 2.1 & 20 & 15 & 13 & \multirow{2}{*}{2.1} & 1 \\
\hline & & & & sub-surface & 40 & 2.1 & 10 & 7 & 6 & & 4 \\
\hline \multirow[t]{2}{*}{8} & 68.305 & 255.913 & 22 & surface & 47 & 2.4 & 13 & 9 & 7 & \multirow[b]{2}{*}{0.8} & 2 \\
\hline & & & & sub-surface & 50 & 2.5 & 16 & 11 & 8 & & 3 \\
\hline \multirow[t]{2}{*}{9} & 68.824 & 264.711 & 23 & surface & 46 & 2.3 & 17 & 12 & 9 & \multirow[b]{2}{*}{1.1} & 2 \\
\hline & & & & sub-surface & 46 & 2.3 & 16 & 11 & 8 & & 2 \\
\hline \multirow[t]{2}{*}{10} & 67.878 & 283.30 & 20 & surface & 41 & 2.1 & 13 & 9 & 8 & \multirow{2}{*}{1.5} & 1 \\
\hline & & & & sub-surface & 36 & 2.0 & 8 & 6 & 5 & & 3 \\
\hline \multirow[t]{2}{*}{11} & 69.280 & 282.954 & 29 & surface & 45 & 2.3 & 14 & 10 & 8 & & 1 \\
\hline & & & & sub-surface & 46 & 2.3 & 9 & 6 & 5 & 1.7 & 3 \\
\hline 12 & 67.155 & 274.739 & 37 & surface & 44 & 2.3 & 16 & 12 & 9 & 14 & 2 \\
\hline & & & & sub-surface & 36 & 2.0 & 10 & 8 & 7 & 1.4 & 4 \\
\hline 13 & 66.762 & 269.309 & 20 & surface & 42 & 2.2 & 11 & 8 & 7 & 06 & 2 \\
\hline & & & & sub-surface & 51 & 2.6 & 23 & 15 & 11 & 0.6 & 2 \\
\hline 14 & 71.151 & 280.752 & 38 & surface & 48 & 2.4 & 12 & 8 & 6 & 20 & 2 \\
\hline & & & & sub-surface & 50 & 2.5 & 7 & 4 & 3 & 2.0 & 5 \\
\hline 15 & 72.341 & 277.654 & 77 & surface & 36 & 2.0 & 13 & 10 & 9 & ? & 2 \\
\hline & & & & sub-surface & 32 & 1.8 & 6 & 5 & 4 & 2.2 & 8 \\
\hline 16 & 72.630 & 261.336 & 19 & surface & 48 & 2.4 & 29 & 20 & 15 & 14 & 1 \\
\hline & & & & sub-surface & 47 & 2.4 & 21 & 14 & 11 & 1.4 & 3 \\
\hline 17 & 72.566 & 259.193 & 27 & surface & 27 & 1.7 & 19 & 15 & 14 & 18 & 1 \\
\hline & & & & sub-surface & 46 & 2.3 & 14 & 10 & 8 & 1.8 & 4 \\
\hline 18 & 73.696 & 260.782 & 42 & surface & 36 & 2.0 & 11 & 9 & 7 & & 1 \\
\hline & & & & sub-surface & 39 & 2.1 & 31 & 21 & 17 & 0.4 & 5 \\
\hline 19 & 76.555 & 255.268 & 18 & surface & 38 & 2.0 & 13 & 10 & 8 & & 2 \\
\hline & & & & sub-surface & 42 & 2.2 & 14 & 10 & 8 & 1.0 & 3 \\
\hline 20 & 76.633 & 263.788 & 21 & surface & 57 & 2.7 & 25 & 16 & 11 & 31 & 1 \\
\hline & & & & sub-surface & 72 & 3.3 & 12 & 6 & 3 & 3.1 & 2 \\
\hline
\end{tabular}


Table 5. Continued.

\begin{tabular}{|c|c|c|c|c|c|c|c|c|c|c|c|}
\hline Site & Lat $\mathrm{N}$ & Lon E & $\begin{array}{r}\text { snow } \\
\text { depth } \\
(\mathrm{cm})\end{array}$ & & $\begin{array}{r}f_{\text {nonBC }}^{\text {est }} \\
(\%)\end{array}$ & $\AA_{\text {tot }}$ & $\begin{array}{c}C_{\mathrm{BC}}^{\text {equiv }} \\
\left(\operatorname{ng~g}^{-1}\right)\end{array}$ & $\begin{array}{c}C_{\mathrm{BC}}^{\max } \\
\left(\mathrm{ng} \mathrm{g}^{-1}\right)\end{array}$ & $\begin{array}{r}C_{\mathrm{BC}}^{\mathrm{est}} \\
\left(\mathrm{ng} \mathrm{g}^{-1}\right)\end{array}$ & $\begin{array}{r}\text { surface: } \\
\text { sub-surf } \\
C_{\mathrm{BC}}^{\text {est }}\end{array}$ & $\begin{array}{r}\# \\
\text { samp. }\end{array}$ \\
\hline \multirow[t]{2}{*}{21} & 75.497 & 263.855 & 26 & surface & 42 & 2.2 & 15 & 10 & 8 & \multirow{2}{*}{0.9} & 2 \\
\hline & & & & sub-surface & 52 & 2.6 & 19 & 12 & 9 & & 3 \\
\hline \multirow[t]{2}{*}{22} & 76.867 & 274.786 & 63 & surface & 49 & 2.5 & 17 & 11 & 9 & \multirow{2}{*}{1.5} & 2 \\
\hline & & & & sub-surface & 43 & 2.2 & 10 & 7 & 6 & & 7 \\
\hline \multirow[t]{2}{*}{23} & 75.460 & 271.149 & 20 & surface & 49 & 2.5 & 39 & 25 & 19 & \multirow{2}{*}{1.9} & 1 \\
\hline & & & & sub-surface & 65 & 3.1 & 28 & 16 & 10 & & 3 \\
\hline \multirow[t]{2}{*}{24} & 75.265 & 269.634 & 25 & surface & 36 & 2.0 & 17 & 13 & 11 & \multirow{2}{*}{0.8} & 2 \\
\hline & & & & sub-surface & 38 & 2.1 & 22 & 16 & 13 & & 3 \\
\hline EUR & 80.083 & 273.300 & $\mathrm{n} / \mathrm{a}$ & surface & 61 & 2.6 & 30 & 18 & 12 & $\mathrm{n} / \mathrm{a}$ & 1 \\
\hline BRW & 71.325 & 203.567 & $\mathrm{n} / \mathrm{a}$ & surface & 53 & 2.6 & 19 & 13 & 9 & $\mathrm{n} / \mathrm{a}$ & 6 \\
\hline MCG & 69.300 & 216.200 & $\mathrm{n} / \mathrm{a}$ & surface & 46 & 2.2 & 9 & 7 & 5 & $\mathrm{n} / \mathrm{a}$ & 2 \\
\hline \multicolumn{12}{|c|}{ Canadian and Alaskan Sub-Arctic (2007) } \\
\hline \multirow[t]{2}{*}{1} & 66.256 & 215.231 & 33 & surface & 39 & 2.1 & 43 & 32 & 31 & \multirow{2}{*}{1.4} & 1 \\
\hline & & & & depth-integrated & 53 & 2.5 & 38 & 25 & 22 & & 1 \\
\hline \multirow[t]{2}{*}{2} & 67.568 & 221.702 & 32 & surface & 39 & 2.1 & 13 & 10 & 9 & \multirow{2}{*}{1.2} & 1 \\
\hline & & & & depth-integrated & 62 & 2.8 & 17 & 10 & 8 & & 1 \\
\hline \multirow[t]{2}{*}{3} & 67.160 & 229.702 & 41 & surface & 40 & 2.0 & 15 & 12 & 11 & \multirow{2}{*}{1.3} & 1 \\
\hline & & & & depth-integrated & 39 & 2.0 & 12 & 9 & 9 & & 1 \\
\hline \multirow[t]{2}{*}{4} & 64.934 & 235.256 & 48 & surface & 53 & 2.5 & 9 & 6 & 5 & \multirow{2}{*}{0.8} & 1 \\
\hline & & & & depth-integrated & 44 & 2.2 & 10 & 7 & 7 & & 1 \\
\hline \multirow[t]{2}{*}{5} & 65.379 & 237.337 & 22 & surface & $\mathrm{n} / \mathrm{a}$ & $\mathrm{n} / \mathrm{a}$ & $\mathrm{n} / \mathrm{a}$ & $\mathrm{n} / \mathrm{a}$ & $\mathrm{n} / \mathrm{a}$ & \multirow{2}{*}{$\mathrm{n} / \mathrm{a}$} & 1 \\
\hline & & & & depth-integrated & 40 & 2.1 & 17 & 13 & 12 & & 1 \\
\hline \multirow[t]{2}{*}{6} & 65.607 & 237.740 & 36 & surface & 33 & 1.8 & 14 & 11 & 11 & & 1 \\
\hline & & & & depth-integrated & 36 & 2.0 & 10 & 8 & 7 & 1.5 & 1 \\
\hline 7 & 65.788 & 238.217 & 23 & surface & 36 & 1.9 & 23 & 18 & 18 & 17 & 1 \\
\hline & & & & depth-integrated & 42 & 2.2 & 15 & 11 & 11 & 1.1 & 1 \\
\hline 8 & 66.230 & 238.934 & 28 & surface & 49 & 2.5 & 14 & 9 & 7 & 04 & 1 \\
\hline & & & & depth-integrated & 41 & 2.1 & 25 & 19 & 18 & 0.4 & 1 \\
\hline 9 & 66.353 & 239.364 & 23 & surface & 33 & 1.9 & 19 & 16 & 16 & 08 & 1 \\
\hline & & & & depth-integrated & 41 & 2.2 & 29 & 21 & 20 & 0.8 & 1 \\
\hline 10 & 66.900 & 241.062 & 34 & surface & 51 & 2.5 & 19 & 13 & 11 & 26 & 1 \\
\hline & & & & depth-integrated & 55 & 2.7 & 8 & 5 & 4 & 2.6 & 1 \\
\hline 12 & 66.655 & 246.440 & 21 & surface & 48 & 2.4 & 63 & 42 & 39 & 35 & 1 \\
\hline & & & & depth-integrated & 37 & 2.0 & 15 & 11 & 11 & 3.5 & 1 \\
\hline 13 & 65.957 & 247.578 & 32 & surface & 46 & 2.3 & 17 & 12 & 9 & 00 & 1 \\
\hline & & & & depth-integrated & 41 & 2.1 & 16 & 12 & 11 & 0.8 & 1 \\
\hline 14 & 65.087 & 248.546 & 28 & surface & 51 & 2.5 & 22 & 15 & 13 & & 1 \\
\hline & & & & depth-integrated & 45 & 2.3 & 21 & 15 & 14 & 0.9 & 1 \\
\hline 15 & 64.747 & 248.146 & 32 & surface & 43 & 2.2 & 31 & 23 & 21 & 13 & 1 \\
\hline & & & & depth-integrated & 41 & 2.1 & 23 & 17 & 17 & 1.3 & 1 \\
\hline 17 & 64.522 & 249.463 & 36 & surface & $\mathrm{n} / \mathrm{a}$ & $\mathrm{n} / \mathrm{a}$ & $\mathrm{n} / \mathrm{a}$ & $\mathrm{n} / \mathrm{a}$ & $\mathrm{n} / \mathrm{a}$ & n & 1 \\
\hline & & & & depth-integrated & 51 & 2.4 & 45 & 29 & 26 & $\mathrm{n} / \mathrm{a}$ & 1 \\
\hline 18 & 64.352 & 250.319 & 33 & surface & 39 & 2.1 & 21 & 16 & 16 & & 1 \\
\hline & & & & depth-integrated & 47 & 2.4 & 20 & 13 & 12 & 1.3 & 1 \\
\hline 19 & 64.086 & 251.489 & 32 & surface & 36 & 2.0 & 46 & 35 & 35 & & \\
\hline & & & & depth-integrated & 37 & 2.0 & 39 & 30 & 30 & 1.2 & 1 \\
\hline
\end{tabular}


Table 5. Continued.

\begin{tabular}{|c|c|c|c|c|c|c|c|c|c|c|c|}
\hline Site & Lat $\mathrm{N}$ & Lon E & $\begin{array}{r}\text { snow } \\
\text { depth } \\
(\mathrm{cm})\end{array}$ & & $\begin{array}{r}f_{\text {nonBC }}^{\text {est }} \\
(\%)\end{array}$ & $\AA_{\text {tot }}$ & $\begin{array}{c}C_{\mathrm{BC}}^{\text {equiv }} \\
\left(\mathrm{ng} \mathrm{g}^{-1}\right)\end{array}$ & $\begin{array}{c}C_{\mathrm{BC}}^{\max } \\
\left(\mathrm{ng} \mathrm{g}^{-1}\right)\end{array}$ & $\begin{array}{r}C_{\mathrm{BC}}^{\mathrm{est}} \\
\left(\mathrm{ngg}^{-1}\right)\end{array}$ & $\begin{array}{r}\text { surface: } \\
\text { sub-surf } \\
C_{\mathrm{BC}}^{\mathrm{est}}\end{array}$ & $\begin{array}{r}\# \\
\text { samp. }\end{array}$ \\
\hline \multirow[t]{2}{*}{20} & 64.011 & 252.424 & 50 & surface & 39 & 2.1 & 25 & 19 & 19 & \multirow{2}{*}{1.4} & 1 \\
\hline & & & & depth-integrated & 44 & 2.3 & 19 & 14 & 13 & & 1 \\
\hline \multirow[t]{2}{*}{21} & 63.751 & 253.456 & 31 & surface & 43 & 2.2 & 14 & 11 & 10 & \multirow{2}{*}{0.6} & 1 \\
\hline & & & & depth-integrated & 44 & 2.2 & 24 & 18 & 16 & & 1 \\
\hline \multirow[t]{2}{*}{22} & 63.611 & 254.872 & 35 & surface & 37 & 2.2 & 21 & 16 & 14 & \multirow{2}{*}{0.5} & 1 \\
\hline & & & & depth-integrated & 37 & 2.0 & 41 & 32 & 31 & & 1 \\
\hline \multirow[t]{2}{*}{23} & 64.041 & 256.155 & 23 & surface & 41 & 2.1 & 18 & 13 & 13 & \multirow{2}{*}{0.9} & 1 \\
\hline & & & & depth-integrated & 41 & 2.1 & 20 & 15 & 14 & & 1 \\
\hline \multirow[t]{2}{*}{24} & 64.017 & 257.490 & 22 & surface & 44 & 2.3 & 24 & 17 & 16 & \multirow{2}{*}{1.5} & 1 \\
\hline & & & & depth-integrated & 45 & 2.3 & 16 & 12 & 11 & & 1 \\
\hline \multirow[t]{2}{*}{25} & 64.533 & 258.646 & 41 & surface & 49 & 2.4 & 16 & 11 & 10 & \multirow{2}{*}{1.0} & 1 \\
\hline & & & & depth-integrated & 45 & 2.3 & 16 & 11 & 10 & & 1 \\
\hline \multirow[t]{2}{*}{26} & 64.620 & 259.527 & 32 & surface & 45 & 2.3 & 24 & 17 & 16 & \multirow{2}{*}{1.9} & 1 \\
\hline & & & & depth-integrated & 45 & 2.3 & 12 & 9 & 8 & & 1 \\
\hline \multirow[t]{2}{*}{27} & 64.578 & 261.450 & 19 & surface & 40 & 2.2 & 21 & 16 & 14 & \multirow{2}{*}{1.5} & 1 \\
\hline & & & & depth-integrated & 40 & 2.1 & 13 & 10 & 10 & & 1 \\
\hline \multirow[t]{2}{*}{28} & 64.419 & 263.579 & 32 & surface & 47 & 2.4 & 11 & 7 & 6 & \multirow{2}{*}{0.6} & 1 \\
\hline & & & & depth-integrated & 40 & 2.1 & 13 & 10 & 10 & & 1 \\
\hline
\end{tabular}

$C_{B C}^{e s t}(\mathrm{ng} / \mathrm{g})$

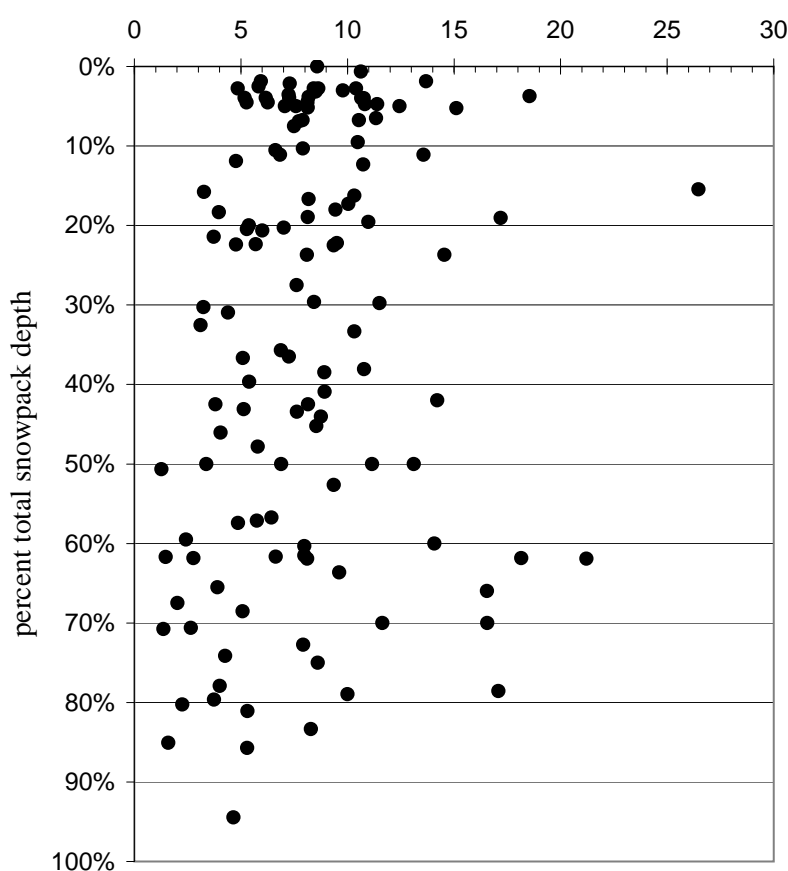

$f_{\text {nonBC }}^{\text {est }}$

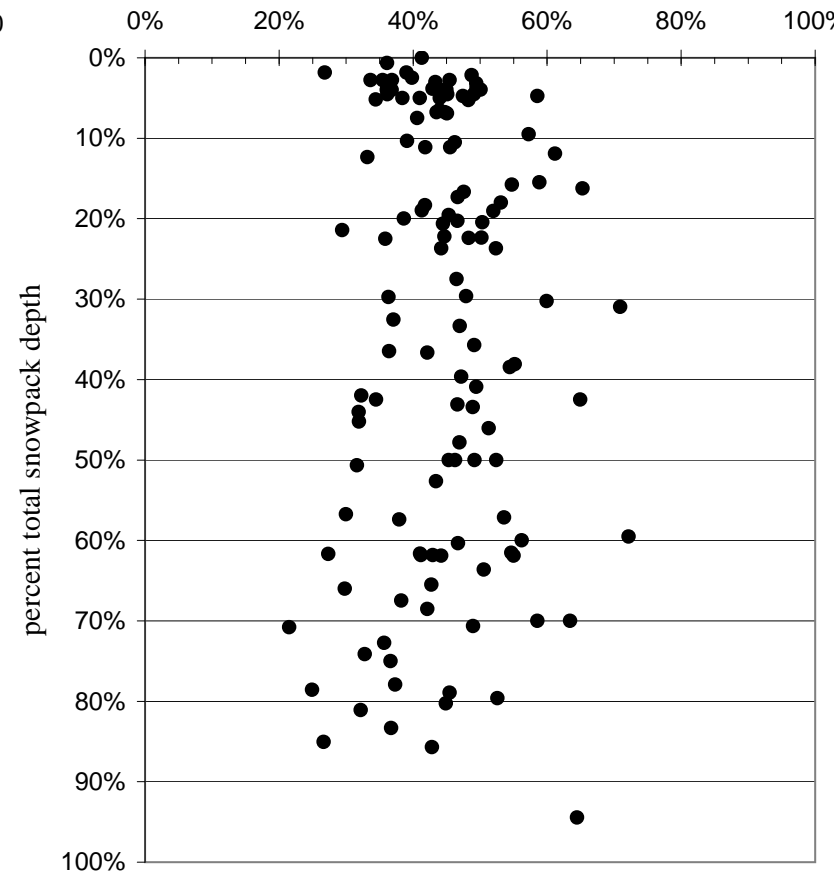

Fig. 9. Profiles from the 2009 Canadian Arctic measurements from 24 sampling sites (Fig. 3) of snow BC concentrations (left) and the fraction of absorption due to non-BC constituents (right). Side-by-side pairs have been averaged together, and the deepest snow samples excluded to avoid contamination by soil or sea-ice algae. Across all 24 sites the snowpack depth was $30 \pm 14 \mathrm{~cm}$. 
Table 6. Median values for samples from Greenland, with medians for surface and sub-surface samples calculated separately. Three Dye-2 profiles which include a melt layer are further broken down by new surface snow, melt layer and below the melt layer.

\begin{tabular}{|c|c|c|c|c|c|c|c|c|c|c|c|c|}
\hline Site & Lat & Lon E & & $\begin{array}{r}f_{\text {nonBC }}^{\text {est }} \\
(\%) \\
\end{array}$ & $\AA_{\text {tot }}$ & $\begin{array}{c}C_{\mathrm{BC}}^{\text {equiv }} \\
\left(\mathrm{ng} \mathrm{g}^{-1}\right)\end{array}$ & $\begin{array}{r}C_{\mathrm{BC}}^{\max } \\
\left(\mathrm{ngg}^{-1}\right)\end{array}$ & $\begin{array}{r}C_{\mathrm{BC}}^{\mathrm{est}} \\
\left(\mathrm{ng} \mathrm{g}^{-1}\right)\end{array}$ & $\begin{array}{r}\text { surface: } \\
\text { sub-surf } \\
C_{\mathrm{BC}}^{\text {est }}\end{array}$ & $\begin{array}{r}\# \\
\text { samp. }\end{array}$ & Year & Notes \\
\hline \multicolumn{13}{|l|}{ Summer Samples } \\
\hline \multirow{2}{*}{$\begin{array}{l}\text { KPCL, } 38 \mathrm{~km} \text { west } \\
\text { of ice margin, } \\
\text { elevation } \sim 1000 \mathrm{~m}\end{array}$} & \multirow[t]{2}{*}{79.878} & \multirow[t]{2}{*}{333.991} & surface & 37 & 2.1 & 31.4 & 23.6 & 20.1 & \multirow[t]{2}{*}{4.2} & 2 & \multirow[t]{2}{*}{2006} & \multirow[t]{2}{*}{$\begin{array}{l}\text { surface snow had } \\
\text { experienced melt }\end{array}$} \\
\hline & & & sub-surface & 39 & 2.3 & 7.9 & 5.7 & 4.8 & & 4 & & \\
\hline $\begin{array}{l}\mathrm{KPCL}, 96 \mathrm{~km} \text { west of } \\
\text { ice margin, } 1439 \mathrm{~m}\end{array}$ & 79.825 & 331.205 & surface & 35 & 2.5 & 1.7 & 1.3 & 1.1 & $\mathrm{n} / \mathrm{a}$ & 2 & 2006 & new drift snow \\
\hline \multirow{2}{*}{$\begin{array}{l}\text { KPCL, } 96 \mathrm{~km} \text { west of } \\
\text { ice margin, } 1439 \mathrm{~m}\end{array}$} & \multirow[t]{2}{*}{79.825} & \multirow[t]{2}{*}{331.205} & surface & 64 & 3.4 & 3.9 & 2.3 & 1.4 & \multirow{2}{*}{1.2} & 2 & \multirow[t]{2}{*}{2006} & \multirow[t]{2}{*}{ surface snow crust } \\
\hline & & & sub-surface & 62 & 3.2 & 2.7 & 1.7 & 1.2 & & 2 & & \\
\hline \multirow[t]{2}{*}{ Summit, $3208 \mathrm{~m}$} & \multirow[t]{2}{*}{72.579} & \multirow{2}{*}{321.496} & surface & 51 & 2.9 & 4.0 & 2.6 & 2.0 & \multirow{2}{*}{1.2} & 1 & \multirow[t]{2}{*}{2007} & \multirow[t]{2}{*}{ dry snow } \\
\hline & & & sub-surface & 49 & 2.7 & 3.2 & 2.2 & 1.7 & & 11 & & \\
\hline \multirow[t]{2}{*}{$\begin{array}{l}\text { Ice sheet above Thule, } \\
\sim 600 \mathrm{~m} \text { and } 1047 \mathrm{~m}\end{array}$} & \multirow[t]{2}{*}{76.402} & \multirow[t]{2}{*}{291.943} & surface & 47 & 2.4 & 8.2 & 5.6 & 4.2 & \multirow[t]{2}{*}{2.0} & 2 & \multirow[t]{2}{*}{2007} & \multirow[t]{2}{*}{$\begin{array}{l}\text { likely experienced } \\
\text { surface melting }\end{array}$} \\
\hline & & & sub-surface & 45 & 2.3 & 3.8 & 2.7 & 2.1 & & 6 & & \\
\hline \multirow[t]{4}{*}{ Dye-2, $2165 \mathrm{~m}$} & \multirow[t]{4}{*}{66.441} & \multirow[t]{4}{*}{315.210} & surface & 33 & 1.9 & 1.6 & 1.3 & 1.1 & \multirow{2}{*}{0.3} & 6 & \multirow[t]{4}{*}{2008} & \multirow{4}{*}{$\begin{array}{l}\text { surface is all new snow } \\
\text { (surface):(below melt) } \\
\text { (melt layer): } \\
\text { (below melt) }\end{array}$} \\
\hline & & & all sub-surface & 46 & 2.4 & 6.6 & 4.6 & 3.8 & & 59 & & \\
\hline & & & melt layer & 39 & 2.1 & 17.8 & 13.0 & 11.0 & 55 & 12 & & \\
\hline & & & below melt layer & 48 & 2.5 & 3.8 & 2.5 & 2.0 & 5.5 & 47 & & \\
\hline Spring Samples at AWS s & ations & & & & & & & & & & & \\
\hline South Dome, $2922 \mathrm{~m}$ & 63.149 & 315.183 & surface & 37 & 2.0 & 7.2 & 5.5 & 4.4 & $\mathrm{n} / \mathrm{a}$ & 2 & 2007 & surface \\
\hline Saddle, $2559 \mathrm{~m}$ & 66.001 & 315.499 & surface & 53 & 2.5 & 3.3 & 2.2 & 1.6 & $\mathrm{n} / \mathrm{a}$ & 2 & 2007,2008 & surface \\
\hline NASA-SE, $2579 \mathrm{~m}$ & 66.480 & 317.500 & surface & 53 & 2.7 & 3.8 & 2.4 & 1.8 & $\mathrm{n} / \mathrm{a}$ & 2 & 2007,2008 & surface \\
\hline Dye-2, $2165 \mathrm{~m}$ & 66.481 & 313.720 & surface & 51 & 2.5 & 7.5 & 4.8 & 3.5 & $\mathrm{n} / \mathrm{a}$ & 2 & 2007,2008 & surface \\
\hline Crawford Point, 2025 m & 69.898 & 313.086 & surface & 42 & 2.2 & 12.0 & 8.7 & 6.9 & $\mathrm{n} / \mathrm{a}$ & 1 & 2008 & surface \\
\hline GITS, $1887 \mathrm{~m}$ & 77.143 & 298.905 & surface & 52 & 2.5 & 6.1 & 4.1 & 2.9 & $\mathrm{n} / \mathrm{a}$ & 1 & 2007 & surface \\
\hline Petermann Glacier, $30 \mathrm{~m}$ & 80.750 & 306.000 & surface & 45 & 2.4 & 6.9 & 4.7 & 3.8 & $\mathrm{n} / \mathrm{a}$ & 1 & 2007 & surface \\
\hline
\end{tabular}
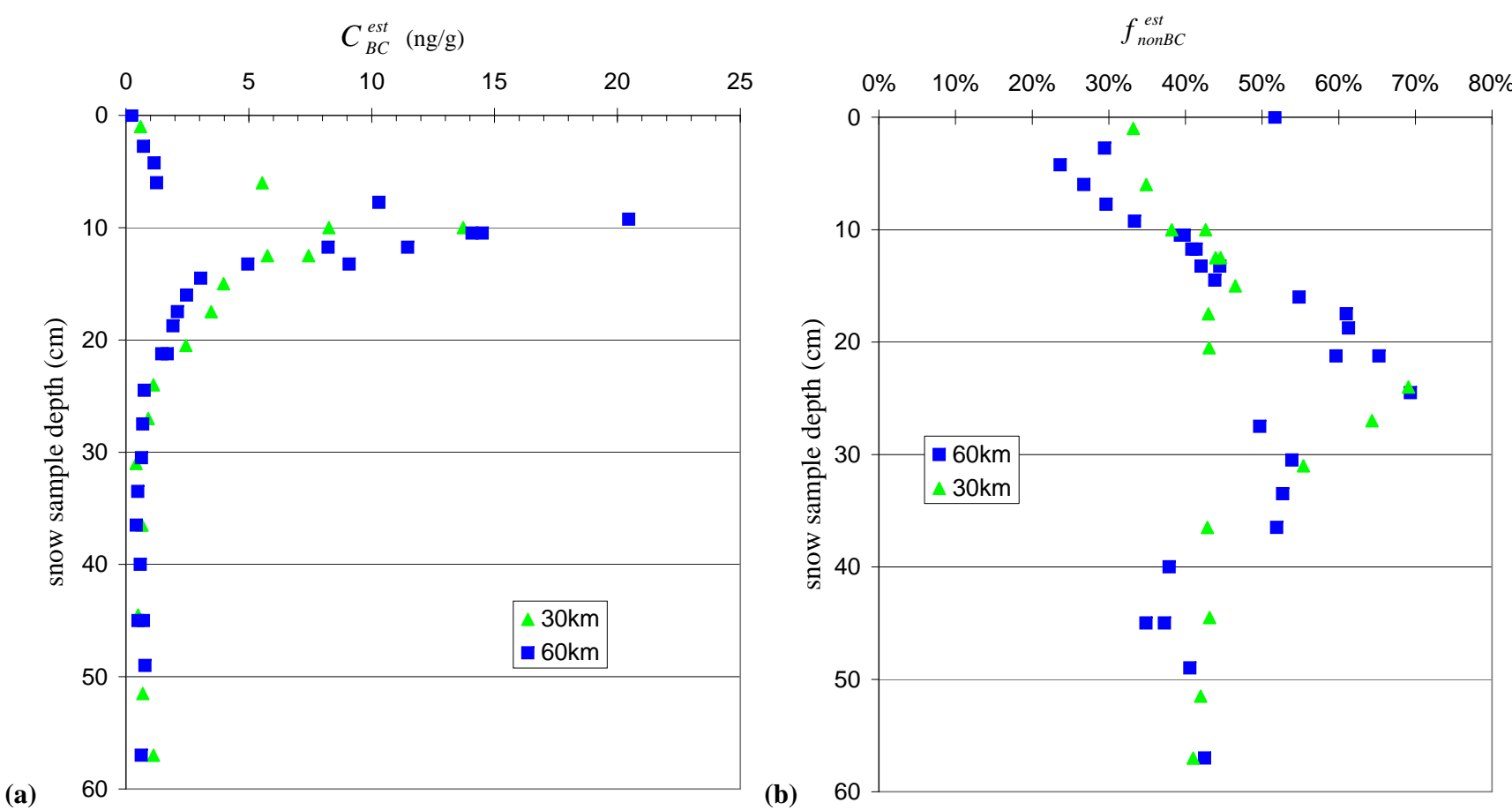

Fig. 10. Profiles of $C_{\mathrm{BC}}^{\text {est }}$ (left) and $f_{\text {nonBC }}^{\text {est }}$ (right) for three summer-time profiles taken $30 \mathrm{~km}$ and $60 \mathrm{~km}$ upwind (south) of the Dye-2 station in Greenland. 
$\sim 15 \mathrm{~cm}$ ). [The deeper snow also included some hard ice lenses from refreezing of meltwater; their BC content was no different from that of the adjacent snow above and below the ice lens.] However, $f_{\text {nonBC }}^{\text {est }}$ is relatively constant through the new snow and the melt layer $(0-15 \mathrm{~cm}$ depth), implying that the type of aerosol - and therefore likely its source - did not change. This is consistent with the idea that BC is largely left behind at the surface as the snow melts (Flanner et al., 2007); quantification of the vertical redistribution will be attempted in a separate paper discussing five separate experiments on snowmelt.

Second, $f_{\text {nonBC }}^{\text {est }}$ is $\sim 25-45 \%$ from the surface down to $\sim 15 \mathrm{~cm}$ and below $\sim 35 \mathrm{~cm}$ but is higher $(\sim 50-70 \%)$ at $15-$ $35 \mathrm{~cm}$ depth. This points to shift in the type of LAA and is consistent with the conclusion that the summertime snow LAA comes predominantly from pollution (lower $f_{\text {nonBC }}^{\text {est }}$ and $\AA_{\text {tot }}$ in the summertime, near-surface snow) and that springtime LAA is from biomass burning (higher $f_{\text {nonBC }}^{\text {est }}$ and $\AA_{\text {tot }}^{\circ}$ at depth, corresponding to snowfall from earlier in the year), as surmised by Hegg et al. (2010) based on chemical analysis of the snow from the $60 \mathrm{~km}$ profile. The $f_{\text {nonBC }}^{\text {est }}$ at $35-60 \mathrm{~cm}$ is similar to that at $0-15 \mathrm{~cm}$, which might suggest that the $35-60-\mathrm{cm}$ layer is snow that fell in the previous year, but this is unlikely because the $\mathrm{BC}$ profile does not show a second summer-melt peak at depth.

\subsubsection{Russia}

Along the Arctic coast of Russia, and indeed across the central Arctic Ocean, the heavy snowfall occurs in autumn (Aleksandrov et al., 2005; Warren et al., 1999). During winter there is little additional snowfall, but considerable sublimation occurs (Liston and Sturm, 2004), which is expected to cause an enhancement of the concentration of impurities in surface snow. Indeed, in most (but not all) of our Siberian sites the BC concentration is higher in surface snow than in subsurface snow (Table 7). The vertical profile for Cherskiy is shown in Fig. 11; this was the site with the highest surface:subsurface ratio.

The BC concentrations (Table 7 and Fig. 12) are much more variable in Russia than in Canada at similar latitudes. This is partly due to the fact that all our sites in Arctic Canada were remote, accessed by skiplane, whereas in Russia we were rarely able to sample snow more than $100 \mathrm{~km}$ from a city, and many of the samples were only $30 \mathrm{~km}$ distant. Local contamination is certainly responsible for the high values at Vorkuta (Table 7). This was the biggest city we used as a base, and we were able to travel only $30 \mathrm{~km}$ east from the city. We have therefore removed Vorkuta from Fig. 2 and from our regional averages in Table 2. We think the values for the three other sites in Western Russia are reliable. Of the three, the lowest surface values of BC (12 $\left.\mathrm{ng} \mathrm{g}^{-1}\right)$ were obtained at Dikson, which is the smallest and most remote town visited. It is on the western corner of the Taymyr Peninsula, protruding into the Kara Sea.

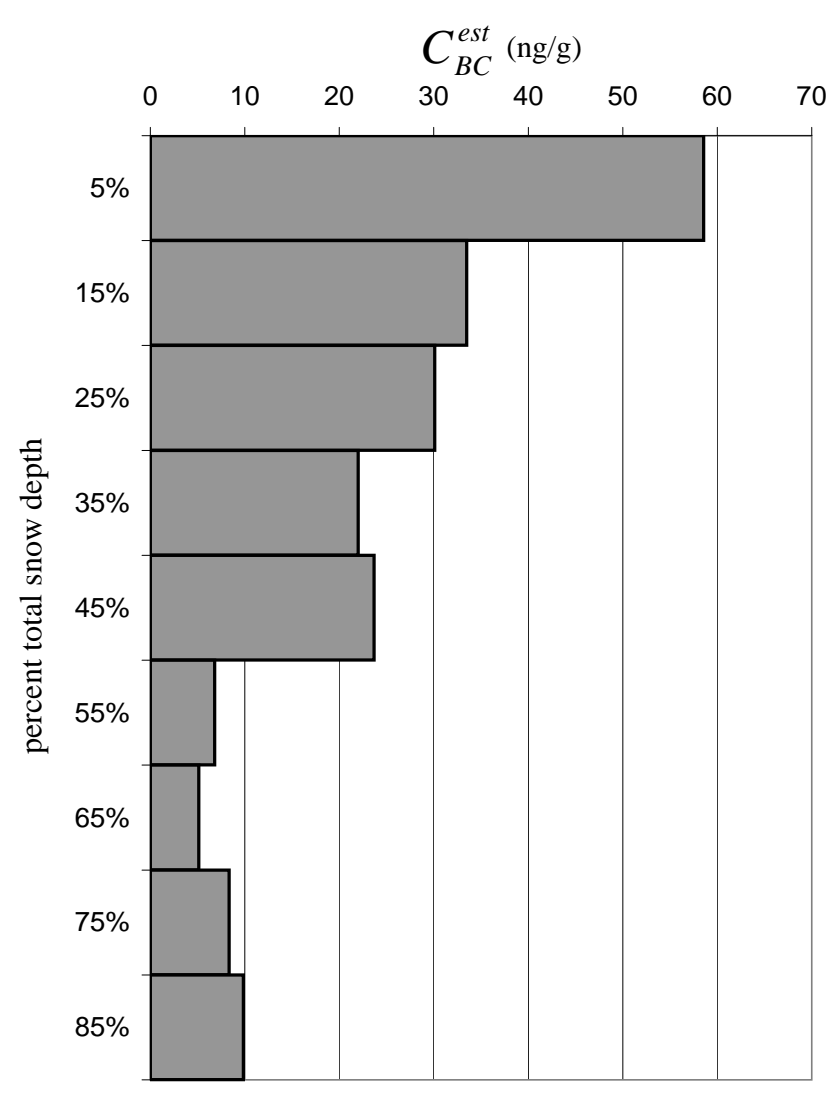

Fig. 11. A profile of $B C$ concentrations in the snowpack in Cherskiy, Russia. The higher values at the surface are indicative of $\mathrm{BC}$ concentration at the snow surface with sublimation, and/or dry deposition of $\mathrm{BC}$ during winter and spring. The low concentrations in the lower part of the snowpack may be affected by self-cleaning in depth hoar (see text).

In Eastern Russia all sites except Yakutsk were near the coast of the Arctic Ocean. Yakutsk is in a subarctic forested region. The Yakutsk-west sites were reached by driving on a lightly-traveled snow-covered road through minor villages; then snow was sampled on a creek and in a frozen marsh. We take these sites to be representative of the Yakutsk region. The Yakutsk-east excursion, by contrast, was along the main highway to Magadan (a gravel road), and there was considerable truck traffic. The road had become snow-free a few days prior to our excursion, so it then became a source of dust for the snow nearby. The higher value of $f_{\text {nonBC }}^{\text {est }}$ at the surface is probably due in part to this local dust, which probably in reality has $\AA_{\text {nonBC }}<5$, so the $C_{\mathrm{BC}}^{\text {est }}$ in Table 7 is exaggerated. The subsurface snow fell earlier when the road was still snow-covered, so it was unaffected by local dust. The subsurface value, $23 \mathrm{ng} \mathrm{g}^{-1}$, agrees with the subsurface value for Yakutsk-west of $20 \mathrm{ng} \mathrm{g}^{-1}$. 
Table 7. Average values for surface and sub-surface snow in Russia. In locations where two adjacent samples (sample pairs) were taken the average of the two pairs is considered a single sample. For the Tiski South site the snow was thin so there are no sub-surface samples. Therefore for that site we show averages for new snow and old snow. The "new snow" at Tiksi was drifting in from the north. The "new snow" at Bilibino had just fallen during the previous few hours in calm weather.

\begin{tabular}{|c|c|c|c|c|c|c|c|c|c|}
\hline & $\begin{array}{r}\text { snow } \\
\text { depth } \\
(\mathrm{cm})\end{array}$ & & $\begin{array}{r}f_{\text {nonBC }}^{\text {est }} \\
(\%)\end{array}$ & $\AA_{\text {tot }}$ & $\begin{array}{c}C_{\mathrm{BC}}^{\text {equiv }} \\
\left(\mathrm{ng} \mathrm{g}^{-1}\right)\end{array}$ & $\begin{array}{r}C_{\mathrm{BC}}^{\max } \\
\left(\mathrm{ng} \mathrm{g}^{-1}\right)\end{array}$ & $\begin{array}{r}C_{\mathrm{BC}}^{\mathrm{est}} \\
\left(\mathrm{ng} \mathrm{g}^{-1}\right)\end{array}$ & $\begin{array}{r}\text { surf: } \\
\text { sub-surf } \\
C_{\mathrm{BC}}^{\text {est }}\end{array}$ & $\begin{array}{r}\# \\
\text { samp. }\end{array}$ \\
\hline \multicolumn{10}{|l|}{ Western Russia (2007) } \\
\hline Nar'yan Mar & \multirow{2}{*}{33} & surface & 23 & 1.6 & 26 & 22 & 19 & \multirow{2}{*}{2.2} & 7 \\
\hline $67.631^{\circ} \mathrm{N}, 53.646^{\circ} \mathrm{E}$ & & sub-surface & 22 & 1.3 & 11 & 9 & 8 & & 4 \\
\hline Vorkuta & \multirow{2}{*}{30} & surface & 23 & 1.5 & 303 & 260 & 235 & \multirow{2}{*}{0.4} & 3 \\
\hline $67.703^{\circ} \mathrm{N}, 64.332^{\circ} \mathrm{E}$ & & sub-surface & 17 & 1.3 & 516 & 469 & 431 & & 2 \\
\hline Dikson & \multirow{2}{*}{35} & surface & 30 & 1.7 & 15 & 14 & 12 & \multirow{2}{*}{0.5} & 5 \\
\hline $73.428^{\circ} \mathrm{N}, 81.481^{\circ} \mathrm{E}$ & & sub-surface & 22 & 1.5 & 35 & 30 & 27 & & 5 \\
\hline Khatanga & \multirow{2}{*}{39} & surface & 21 & 1.5 & 60 & 53 & 48 & \multirow{2}{*}{1.5} & 5 \\
\hline $72.256^{\circ} \mathrm{N}, 103.038^{\circ} \mathrm{E}$ & & sub-surface & 25 & 1.6 & 43 & 36 & 32 & & 6 \\
\hline \multicolumn{10}{|l|}{ Eastern Russia (2008) } \\
\hline Yakutsk West & \multirow{2}{*}{37} & surface & 48 & 2.8 & 102 & 69 & 54 & \multirow{2}{*}{2.9} & 3 \\
\hline $62.714^{\circ} \mathrm{N}, 129.159^{\circ} \mathrm{E}$ & & sub-surface & 28 & 1.9 & 30 & 24 & 20 & & 3 \\
\hline Yakutsk East & \multirow{2}{*}{28} & surface & 51 & 2.6 & 238 & 154 & 116 & \multirow{2}{*}{6.1} & 1 \\
\hline $62.134^{\circ} \mathrm{N}, 130.538^{\circ} \mathrm{E}$ & & sub-surface & 28 & 1.7 & 33 & 27 & 23 & & 2 \\
\hline Tiksi South & \multirow{2}{*}{$<10$} & new snow & 51 & 2.6 & 23 & 16 & 11 & \multirow{2}{*}{$\mathrm{n} / \mathrm{a}$} & 4 \\
\hline $71.576^{\circ} \mathrm{N}, 128.861^{\circ} \mathrm{E}$ & & old snow & 49 & 2.5 & 289 & 188 & 146 & & 8 \\
\hline Tiksi North & \multirow{2}{*}{38} & surface & 45 & 2.4 & 236 & 162 & 130 & \multirow{2}{*}{3.4} & 3 \\
\hline $72.040^{\circ} \mathrm{N}, 128.460^{\circ} \mathrm{E}$ & & sub-surface & 35 & 2.0 & 68 & 53 & 46 & & 3 \\
\hline Tiksi West & \multirow{2}{*}{31} & surface & 34 & 2.0 & 77 & 60 & 52 & \multirow{2}{*}{1.6} & 4 \\
\hline $71.707^{\circ} \mathrm{N}, 127.534^{\circ} \mathrm{E}$ & & sub-surface & 29 & 1.8 & 78 & 64 & 57 & & 3 \\
\hline Laptev Sea & \multirow{2}{*}{$<10$} & surface & 43 & 2.3 & 24 & 17 & 13 & \multirow{2}{*}{$\mathrm{n} / \mathrm{a}$} & 3 \\
\hline $74.065^{\circ} \mathrm{N}, 128.872^{\circ} \mathrm{E}$ & & sub-surface & 30 & 1.8 & 37 & 31 & 26 & & 1 \\
\hline Cherskiy West & \multirow{2}{*}{35} & surface & 30 & 1.8 & 110 & 89 & 78 & \multirow{2}{*}{6.0} & 6 \\
\hline $68.649^{\circ} \mathrm{N}, 160.487^{\circ} \mathrm{E}$ & & sub-surface & 34 & 1.9 & 21 & 16 & 13 & & 5 \\
\hline Cherskiy North & 24 & surface & 27 & 1.7 & 69 & 57 & 50 & & 4 \\
\hline $69.032^{\circ} \mathrm{N}, 161.201^{\circ} \mathrm{E}$ & 24 & sub-surface & 29 & 1.7 & 36 & 30 & 26 & 1.9 & 4 \\
\hline Cherskiy East & & surface & 34 & 1.9 & 82 & 63 & 53 & & 2 \\
\hline $68.719^{\circ} \mathrm{N}, 161.572^{\circ} \mathrm{E}$ & 37 & sub-surface & 34 & 1.9 & 29 & 22 & 18 & 3.1 & 2 \\
\hline Cherskiy-Bilibi. traverse & 32 & surface & 38 & 2.1 & 28 & 21 & 17 & & 1 \\
\hline $68.487^{\circ} \mathrm{N}, 163.157^{\circ} \mathrm{E}$ & 32 & sub-surface & 31 & 1.9 & 13 & 10 & 9 & 1.9 & 1 \\
\hline Bilibino & & surface & 46 & 2.3 & 25 & 18 & 14 & & 1 \\
\hline $68.221^{\circ} \mathrm{N}, 166.179^{\circ} \mathrm{E}$ & 40 & sub-surface & 49 & 2.5 & 19 & 13 & 10 & 1.4 & 1 \\
\hline & & new snow & 56 & 2.8 & 7 & 5 & 3 & $\mathrm{n} / \mathrm{a}$ & 1 \\
\hline Pevek West & & surface & 48 & 2.4 & 22 & 15 & 11 & & 2 \\
\hline $69.869^{\circ} \mathrm{N}, 169.302^{\circ} \mathrm{E}$ & 29 & sub-surface & 49 & 2.5 & 18 & 13 & 10 & 1.7 & 2 \\
\hline Pevek East & & surface & 47 & 2.4 & 24 & 17 & 13 & & 2 \\
\hline $69.524^{\circ} \mathrm{N}, 171.310^{\circ} \mathrm{E}$ & 50 & sub-surface & 47 & 2.4 & 25 & 17 & 13 & 1.0 & 2 \\
\hline Pevek South & & surface & 50 & 2.5 & 28 & 19 & 14 & & 4 \\
\hline $69.119^{\circ} \mathrm{N}, 170.858^{\circ} \mathrm{E}$ & 20 & sub-surface & 48 & 2.4 & 20 & 14 & 11 & 1.4 & 4 \\
\hline
\end{tabular}

The other extremely high estimates of $\mathrm{BC}$ are for Tiksisouth. This was a tundra site reached by walking $3.4 \mathrm{~km}$ west of the weather station, which in turn is just $7 \mathrm{~km}$ south of the town. The snow was thin and patchy (Fig. 13), so there is the possibility of local sources of dust entering the snow. The
non-BC fractions given as 48-55\% in Table 7 may in reality be e.g. $\sim 90 \%$ if the dust has $\AA_{\text {nonBC }} \approx 2.5$ instead of 5.0. We conclude that the true $\mathrm{BC}$ values for Tiksi are probably much lower than indicated in Table 7. 

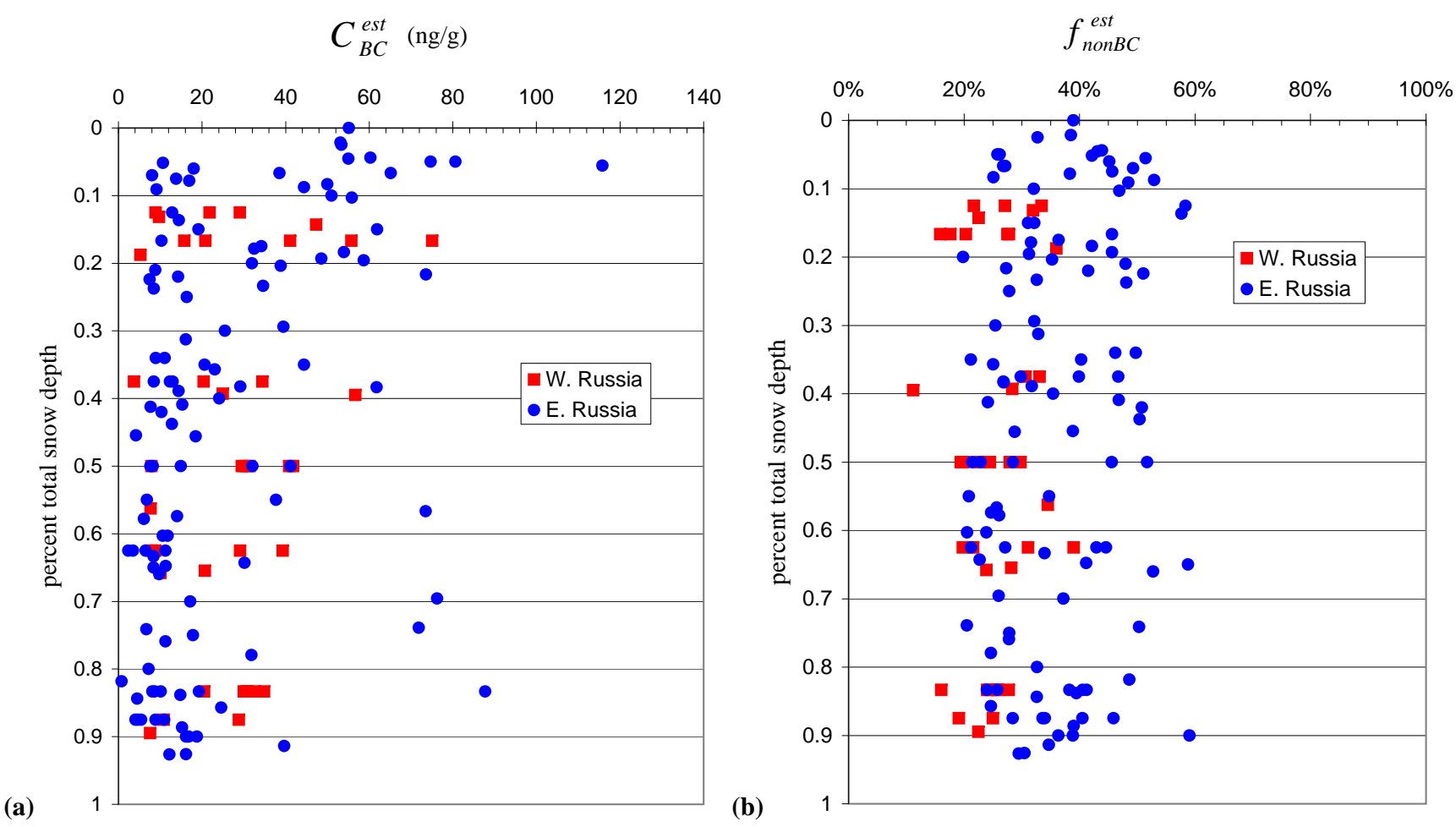

Fig. 12. As in Fig. 9, but for from West (2007) and East (2008) Russia. . Note that the scale for $C_{\mathrm{BC}}^{\text {est }}$ here differs from that in Fig. 9. Here we have included data only where there were samples from more than three snow depths. This excludes much of the data from the Tiksi and Laptev Sea sites, where the snow was thin. Data from Vorkuta were also not included here.

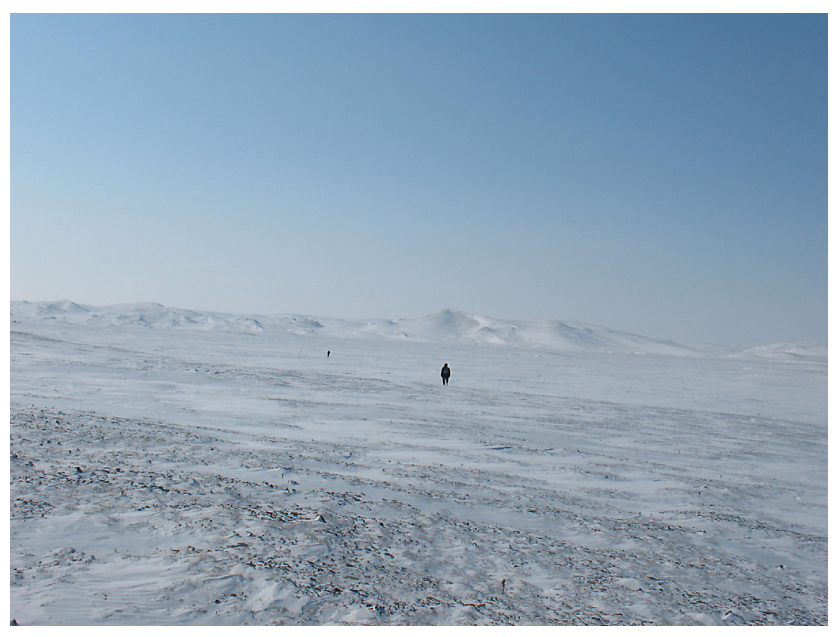

Fig. 13. A photo of the Tiksi-South sampling area, in eastern Russia, in early April.

The northward excursion from Tiksi was a drive on sea ice in the Lena Delta, but always close to land; it is possible that the high value of $C_{\mathrm{BC}}^{\text {est }}=130 \mathrm{ng} \mathrm{g}^{-1}$ is also contaminated by dust with a wrong assumed value of $\AA_{\text {nonBC. It is }}$ interesting that the $\mathrm{BC}$ values for snow on the Laptev Sea, just $200 \mathrm{~km}$ north of Tiksi (obtained on a helicopter excur- sion), are so much smaller. It seems likely that they, rather than any of the sites near Tiksi, represent the true regional values of BC: $13 \mathrm{ng} \mathrm{g}^{-1}$ for surface snow, and $26 \mathrm{ng} \mathrm{g}^{-1}$ for subsurface snow. We cannot be sure that the higher value for subsurface snow represents a repeatable seasonal difference; it may instead be due to a single forest-fire plume that happened to affect this location. The climatological average snow depth in April at the Laptev location is $\sim 25 \mathrm{~cm}$, but this year the depth was only $7-10 \mathrm{~cm}$, probably because the sea ice formed later than usual in autumn 2007 (Stroeve et al., 2008); any early-autumn precipitation would have fallen into seawater instead of accumulating on the ice surface.

Cherskiy is located at the forest/tundra transition in the Kolyma River basin. There are local sources of soot within the river basin from domestic wood-burning in the villages and fishing camps, as well as coal-fired power plants. A thermal inversion confines much of this pollution to the river basin in winter, so there may be significant dry deposition, and indeed we saw black particles on the filters that were large enough to be resolved by eye. Our reported values for the Cherskiy region may therefore be representative only of the (admittedly vast) Kolyma River basin, and not of the surrounding highlands. Samples from higher elevation were obtained on the drive from Cherskiy to Bilibino, and their BC estimates are indeed lower $\left(17 \mathrm{ng} \mathrm{g}^{-1}\right.$ surface, $9 \mathrm{ng} \mathrm{g}^{-1}$ subsurface). These samples may be taken to represent the high- 
lands surrounding the river basin, with the caveat that they were by necessity collected not far from the main east-west road across northwestern Chukotka. The source-attribution for these sites, however, does implicate biomass burning rather than diesel emissions (Hegg et al., 2010), so we think the values are regionally representative.

The snowpacks across the Siberian tundra consisted mostly of depth hoar except for the top 5-10 cm, which was consolidated fine-grained old snow. Depth hoar results from strong vertical temperature gradients in a shallow snowpack whose base at the ground surface is much warmer than the top surface exposed to the cold atmosphere (LaChapelle, 1969). The consequence is sublimation of snow grains and re-deposition of the vapor as frost crystals ("depth hoar") a few $\mathrm{mm}$ higher. This process, during which the entire subsurface snowpack passes through the vapor phase, is repeated many times during the winter, suggesting a self-cleaning mechanism for the snowpack, in which the soot migrates downward relative to the snow. Indeed, we never found high $\mathrm{BC}$ concentrations in depth hoar. This mechanism, however, does not affect the surface layer, which retains high BC concentrations, and of course it is the surface layer that largely determines the albedo.

Table 7 shows that our estimated BC values generally decrease toward the east, from Tiksi to Cherskiy to Bilibino to Pevek. Three excursions in different directions from Pevek all obtained $C_{\mathrm{BC}}^{\text {est }}$ values in the range $10-14 \mathrm{ng} \mathrm{g}^{-1}$, both in surface and sub-surface snow. The lowest value in Eastern Siberia, $3 \mathrm{ng} \mathrm{g}^{-1}$, was obtained for newly fallen snow sampled on 29 April in Bilibino, near the city center. This was the only snowfall event experienced during the 7-week expedition in Eastern Siberia.

The estimated non-BC contributions to absorption are small in Western Russia (17-30\%), similar to Norway and Svalbard. They are also small in the Cherskiy region, where much of the BC may come from local sources as discussed above. Otherwise the estimated fractional absorption due to non-BC in eastern Siberia (Table 7 and Fig. 12) is similar to what we find in arctic Canada, consistent with a predominance of biomass burning as the source of $\mathrm{BC}$, as found by Hegg et al. (2009, 2010). The biomass burning consists of both agricultural fires and forest fires, but apparently both sources are largely "anthropogenic" (Mollicone et al., 2006).

\subsubsection{Norway and Svalbard}

We have samples from two general locations separated by $\sim 10^{\circ}$ in latitude (Fig. 2, Table 8). At Troms $\varnothing$, snow was collected periodically by Sanja Forsström of NPI on a mountain plateau (Fjellheisen) east of the city between 26 March and 30 May 2008. Samples were taken on one day each in March and April, then more regularly from 19 May to 30. On 21 May, the snow began to melt and it continued to melt through 30 May. Vertical profiles of snow samples were gathered both before and during the melt period, to show how the surface and sub-surface concentrations of BC evolved as the snow melted. While the sub-surface concentrations increased only slightly across this span of time $\left(C_{\mathrm{BC}}^{\text {est }}\right.$ $21 \mathrm{ng} \mathrm{g}^{-1}$ vs. $16 \mathrm{ng} \mathrm{g}^{-1}$ ), BC concentrations in surface snow increased from $18 \mathrm{ng} \mathrm{g}^{-1}$ to $56 \mathrm{ng} \mathrm{g}^{-1}$, indicating that there was incomplete removal of the $\mathrm{BC}$ with the melt water, and possibly some $\mathrm{BC}$ transferred from the surface to the subsurface snow. The ratio of surface:sub-surface $C_{\mathrm{BC}}^{\text {est }}$ increased from 1.1 before melting to 2.7 after 9 days of snowmelt.

Ten degrees north of Troms $\varnothing$, on the west side of Spitsbergen, the largest island of Svalbard, snow was collected near Kongsfjord. (Coal mining is a major industry in Svalbard; the nearest major coal mine is at Barentsburg, $110 \mathrm{~km}$ south of Kongsfjord. However, BC from that mine appears to affect the snow only a short distance from Barentsburg; Forsström et al., 2009.) Deposited snow was collected from three sites in March-April 2007, and the glacier site was resampled two years later (May 2009). Samples of new snowfall were collected from mid-March to late May 2007 in the science-town of Ny-Ålesund on Kongsfjord. Samples were collected both at the research laboratory in the town near sea level and at the Zeppelin station, $475 \mathrm{~m}$ a.s.1.; they showed no systematic difference in BC concentrations. All samples were of cold snow which had not yet experienced melt. BC concentrations in surface snow were lower here $\left(7-16 \mathrm{ng} \mathrm{g}^{-1}\right)$ than in Troms $\varnothing$ pre-melt $\left(\sim 19 \mathrm{ng} \mathrm{g}^{-1}\right)$, as would be expected given its greater distance from European sources. For two of the three Svalbard sites the ratio of $C_{\mathrm{BC}}^{\text {est }}$ surface:sub-surface is similar to that in Troms $\varnothing$ pre-melt, possibly indicative of a generally higher concentration of $\mathrm{BC}$ in snow deposited in spring than in late winter. The surface Ångstrom exponent is also slightly but systematically lower than in the sub-surface, indicating a relatively greater role of fossil fuel $\mathrm{BC}$ in spring than in winter. At the third Svalbard site (moraine below glacier), the surface:sub-surface $C_{\mathrm{BC}}^{\text {est }}$ ratio is much higher (2.6 vs. $1.2-$ 1.3). This is based on one sample each from the surface and sub-surface. We also have a sample of newly fallen snow in the nearby town of Ny-Ålesund from the same day (1 April), and it has the same $C_{\mathrm{BC}}^{\text {est }}$ as below the glacier $\left(17 \mathrm{ng} \mathrm{g}^{-1}\right)$. Thus, the high surface:sub-surface ratio may just be indicative of capturing a short-term change from cleaner to dirtier snowfall. On the other hand, the moraine site was near an established snowmobile route, so it could have experienced local pollution.

Inspection of $C_{\mathrm{BC}}^{\text {est }}$ for the new-snow events (Fig. 14) shows that $\mathrm{BC}$ concentrations in deposited snow are highly variable in March and April, with a general tendency to lower concentrations in moving from early to late spring, as was also seen by Noone and Clarke (1988) in northern Sweden during the springtime decline of Arctic haze. This high variability in March-April also makes it difficult to know whether the higher BC concentration in 2009 vs. 2007 at the upper glacier site (Table 8) is due to differences in emissions/deposition between the two years or if it instead just reflects the high 
Table 8. Median values from the Fjellheisen plateau above Troms $\varnothing$, Norway $\left(69.4^{\circ} \mathrm{N}, 18.6^{\circ} \mathrm{E}, 421 \mathrm{~m}\right)$ in the spring of 2008 , and from Svalbard in 2007 and 2009. All Svalbard samples are from near the town of Ny-Ålesund $\left(78.917^{\circ} \mathrm{N}, 11.933^{\circ} \mathrm{E}\right)$. In locations where two adjacent samples were taken, the average of the pair is considered a single sample. In Troms $\varnothing$, the total snow depth was $27 \mathrm{~cm}$ immediately before melt commenced.

\begin{tabular}{|c|c|c|c|c|c|c|c|}
\hline & $\begin{array}{r}f_{\text {nonBC }}^{\text {est }} \\
(\%)\end{array}$ & $\AA_{\text {tot }}$ & $\begin{array}{c}C_{\mathrm{BC}}^{\text {equiv }} \\
\left(\mathrm{ng} \mathrm{g}^{-1}\right)\end{array}$ & $\begin{array}{r}C_{\mathrm{BC}}^{\max } \\
\left(\operatorname{ng~g}^{-1}\right)\end{array}$ & $\begin{array}{r}C_{\mathrm{BC}}^{\mathrm{est}} \\
\left(\mathrm{ng} \mathrm{g}^{-1}\right)\end{array}$ & $\begin{array}{r}\text { surface: } \\
\text { sub-surf } \\
C_{\mathrm{BC}}^{\text {est }}\end{array}$ & $\begin{array}{r}\# \\
\text { samp. }\end{array}$ \\
\hline \multicolumn{8}{|c|}{ Troms $\varnothing$ : PRE-MELT (26 March and 15 April) } \\
\hline surface & 22 & 1.1 & 24 & 21 & 19 & \multirow{2}{*}{1.1} & 3 \\
\hline sub-surface & 29 & 1.8 & 23 & 19 & 17 & & 9 \\
\hline \multicolumn{8}{|c|}{ Troms $\emptyset$ : PRE-MELT (19, 21 May) } \\
\hline surface & 27 & 1.7 & 24 & 20 & 18 & \multirow{2}{*}{1.1} & 3 \\
\hline sub-surface & 29 & 1.7 & 23 & 19 & 16 & & 14 \\
\hline \multicolumn{8}{|c|}{ Troms $\varnothing:$ DURING MELT (23, 26, 28, 30 May) } \\
\hline surface & 29 & 1.8 & 80 & 64 & 56 & \multirow{2}{*}{2.7} & 4 \\
\hline sub-surface & 33 & 1.9 & 31 & 24 & 21 & & 21 \\
\hline \multicolumn{8}{|c|}{ Svalbard, Upper Brøggerbreen glacier, $78.874^{\circ} \mathrm{N}, 11.923^{\circ} \mathrm{E}$} \\
\hline surface, 2007 & 31 & 2.0 & 11 & 9 & 8 & \multirow{3}{*}{1.2} & 2 \\
\hline sub-surface 2007 & 28 & 2.0 & 9 & 7 & 6 & & 4 \\
\hline surface, 2009 & 21 & 1.5 & 19 & 16 & 15 & & 1 \\
\hline \multicolumn{8}{|c|}{ Svalbard, 2007, moraine below Brøggerbreen, $78.910^{\circ} \mathrm{N}, \mathrm{E} 11.830^{\circ} \mathrm{E}$} \\
\hline surface & 22 & 1.6 & 21 & 18 & 17 & \multirow{2}{*}{2.6} & 1 \\
\hline sub-surface & 31 & 2.0 & 9 & 8 & 7 & & 1 \\
\hline \multicolumn{8}{|c|}{ Svalbard tundra, $240 \mathrm{~m}$ from shore of Kongsfjord, $2007\left(78.903^{\circ} \mathrm{N}, 12.117^{\circ} \mathrm{E}\right)$} \\
\hline surface & 33 & 1.9 & 11 & 8 & 7 & \multirow{2}{*}{1.3} & 4 \\
\hline sub-surface & 46 & 2.5 & 11 & 8 & 6 & & 2 \\
\hline \multicolumn{8}{|c|}{ Newly Fallen Snow at Ny-Ålesund, 2007} \\
\hline March & 30 & 2.0 & 21 & 17 & 15 & $\mathrm{n} / \mathrm{a}$ & 11 \\
\hline April & 32 & 1.8 & 29 & 23 & 20 & $\mathrm{n} / \mathrm{a}$ & 10 \\
\hline May & 25 & 1.6 & 14 & 11 & 10 & $\mathrm{n} / \mathrm{a}$ & 3 \\
\hline
\end{tabular}

short-term variability seen in Fig. 14. While we do not have samples of individual snowfall events from the Canadian side of the Arctic, the very low site-to-site and vertical variability in snow concentrations across Arctic Canada (Fig. 9) indicates that the temporal variability on that side of the Arctic is much smaller than in Svalbard.

New-snow events with high concentrations of $\mathrm{BC}$ are associated with lower values of $\AA_{\text {tot }}$ (Fig. 15), again indicating that fossil-fuel pollution likely accounts for much of the $\mathrm{BC}$ in snow on this side of the Arctic. The excellent coincidence of the Ny-Ålesund and Troms $\emptyset$ values in Fig. 15 further suggests that the two locations are influenced by the same sources, with lower concentrations at the northern site through dilution with transport.
The values we obtain for Svalbard, with medians 7 $20 \mathrm{ng} \mathrm{g}^{-1}$, are higher than those obtained by Forsström et al. (2009) using the TO method. Their median for 81 samples across Svalbard was $4 \mathrm{ng} \mathrm{g}^{-1}$. We have commonly seen factor-of-two differences when processing the same snow by the two methods, with our filter method giving larger values. Investigation of the discrepancy is underway, in collaboration with the NPI.

\section{Uncertainty analysis}

Uncertainty in the results presented above stem from (a) instrumental noise and instability, which will introduce random uncertainties, (b) uncertainties in the assumptions built into our data analysis, which may be introducing biases, 


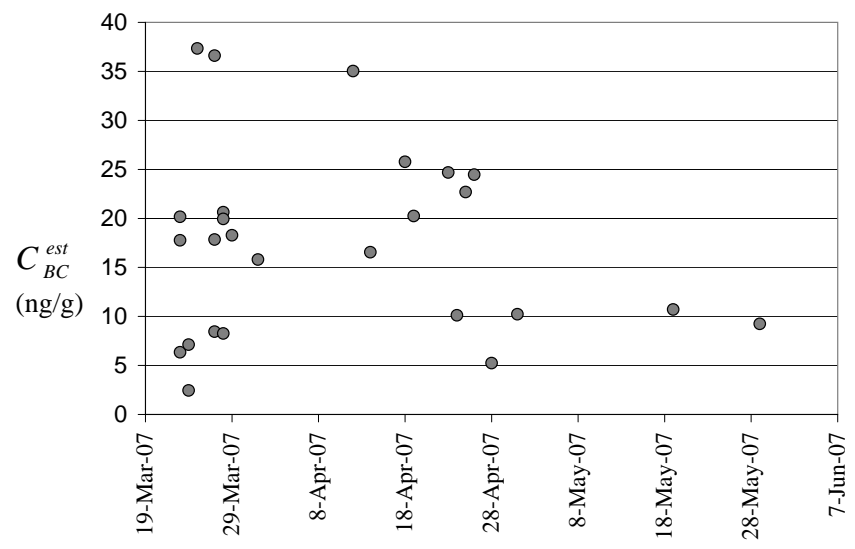

Fig. 14. Time-series of $\mathrm{BC}$ concentrations in newly fallen snow at Ny-Ålesund, Svalbard $\left(79^{\circ} \mathrm{N}, 12^{\circ} \mathrm{E}\right)$, in 2007.

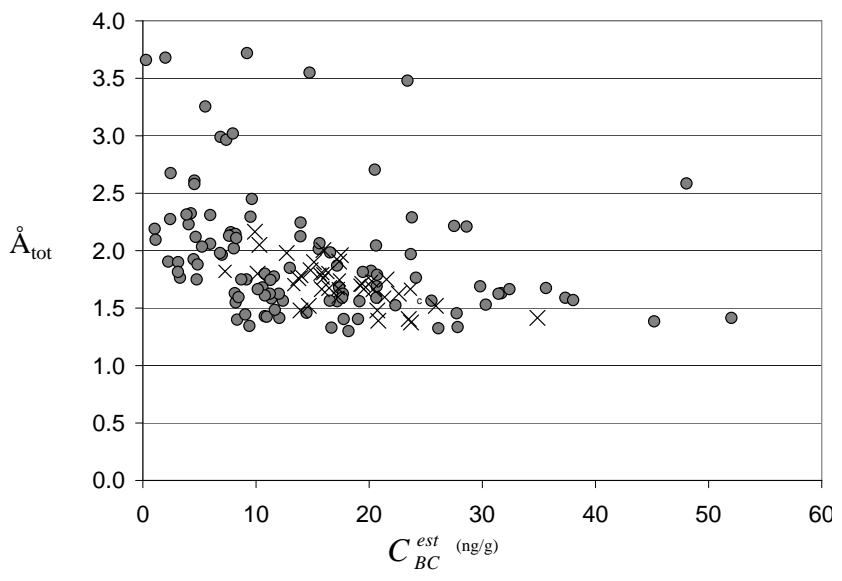

Fig. 15. $\AA_{\text {tot }}$ vs. $C_{\mathrm{BC}}^{\mathrm{est}}$ at Ny-Ålesund (gray circles) and Troms $\varnothing$ $\left(69^{\circ} \mathrm{N}, 19^{\circ} \mathrm{E}\right.$; crosses) in 2008 before the onset of melt.

(c) non-uniformity in the deposition of sample aerosol onto the nuclepore filters, which may introduce random errors for some samples, and (d) the question of whether the samples analyzed are representative of a broader region.

The latter two sources of error relate to our sampling and filtering procedures. In all cases efforts were made to gather snow samples far enough away from local sources of pollution (e.g. roads, snowmobile tracks, industrial complexes, cities) that they would not significantly influence snow BC concentrations. Where there was doubt, we often gathered snow samples at increasing distances from possible sources and only kept samples where concentrations had ceased to decline with distance from the source. However, the definition of "regionally representative" and "significantly influenced" are by necessity somewhat arbitrary, and the limited number of samples that can be gathered from any one region limit their broader representativeness. In areas where relatively little spatial variability in concentrations was observed, such as Arctic Canada, our regional averages are more likely to be representative; in regions with high variability, such as northern Russia, they are less likely to be representative of a broader region. In the specific case of our samples from near Vorkuta, Russia, it appears that we were unsuccessful at getting far enough from the city to escape its influence. On the other hand, this points to the fact that some sources may be large enough to be regionally important. At the smaller scale $(\sim 1-10 \mathrm{~m})$ we have addressed the question of the representativeness of our samples by taking two side-by-side samples at many locations. Our analysis of these samples (Sect. 5.1 and Fig. 6) shows that the two concentrations are typically within $20-30 \%$ of each other. Where duplicate samples were taken, the average of the two values is used in the analysis.

Once gathered, snow samples are melted then filtered, with an exposed area of $18 \mathrm{~mm}$ diameter. The field of view of the laboratory spectrophotometer is $<5 \mathrm{~mm}$ so uneven distribution of the aerosol on the filter could bias our results. We test for this - as well as to identify spurious results produced by, e.g., instrument malfunction or the filter sliding outside the photometer field of view - by measuring each filter twice, with the filter repositioned for the second measurement. If the difference between the two measurements is $>10 \%$ we re-measure the filter. If consecutive measurements of different parts of the filter exposed area do not agree within $10 \%$ we exclude the sample from our analysis, so error due to uneven filter exposure should be limited to $\sim 10 \%$. Less than $1 \%$ of field samples were excluded in this way.

Tests of the ISSW spectrophotometer have shown that the instrumental noise is small $(<1 \%$ for the averaging time used). The system calibration also is stable: we observed $\sim 2.5 \%$ drift in the calibration over several months and $<0.5 \%$ drift over several hours (Grenfell et al., 2010). We measure the calibration standards approximately every other day we measure filters, so errors due to calibration drift likely fall between $0.5 \%$ and $2.5 \%$. Uncertainty in the calibration (conversion from measured light intensity to absorption optical depth or BC loading on the filter) as a function of filter loading and wavelength, derived by running multiple calibrations over a six-month period, shows that the calibration uncertainty is $<10 \%$ for filter loadings of $0.12-7 \mu \mathrm{gBC} \mathrm{cm}^{2}$ over the $420-740 \mathrm{~nm}$ wavelength range (90\% of all samples); it is $<5 \%$ for loadings of $0.5-5 \mu \mathrm{gBC} \mathrm{cm} \mathrm{cm}^{-2}$ (79\% of all samples) (Grenfell et al., 2010). These instrumental uncertainties $(<11 \%$ when added in quadrature) produce randomly distributed error and are therefore minimized by averaging across multiple samples.

Several assumptions built into our analysis may be producing systematic biases. First, we apply a $15 \%$ under-catch correction to all samples based on tests on field samples from a range of locations. These tests indicated that the undercatch of the filters may be as low as $0 \%$ or as high as $30 \%$, as stated in Sect. 3.2, with under-catch varying by location (i.e. presumably by aerosol type). We did not conduct sufficient tests to be able to apply a location-specific undercatch correction, so in some locations we may be introducing 
either low or high bias in $C_{\mathrm{BC}}^{\max }, C_{\mathrm{BC}}^{\text {est }}$ and $C_{\mathrm{BC}}^{\text {equiv }}$ of as much as $15 \%$. Second, for sites where plastic zip-loc bags were used to collect snow samples (sub-arctic Canada and western Russia) we have applied a $20 \%$ correction factor to account for losses of BC to plastic flakes scratched off in the bags (Sect. 3.1). Tests to assess these losses (sampling the same snow layer with both scratchable and nonscratchable bags) obtained losses ranging from 0 to $40 \%$ on eight different snow layers, so we estimate the uncertainty of the correction factor to be $\pm 20 \%$, affecting $C_{\mathrm{BC}}^{\max }, C_{\mathrm{BC}}^{\text {est }}$ and $C_{\mathrm{BC}}^{\text {equiv }}$ for the samples from sub-arctic Canada and western Russia only.

The largest source of uncertainty in our analysis stems from uncertainty in the mass absorption efficiency of $\mathrm{BC}$ (affecting $C_{\mathrm{BC}}^{\max }, C_{\mathrm{BC}}^{\text {est }}, C_{\mathrm{BC}}^{\text {equiv }}$ and $f_{\text {nonBC }}^{\text {est }}$ ) and uncertainty in the absorption Angstrom exponent of $\mathrm{BC}$ and non-BC constituents in our samples (affecting $C_{\mathrm{BC}}^{\mathrm{est}}$ and $f_{\mathrm{nonBC}}^{\text {est }}$ ).

The ISSW measures light absorption, and the conversion to BC mass is made using a set of standard filters loaded with known amounts of synthetic soot (Sect. 3.3). The mass absorption efficiency, $\beta_{\mathrm{abs}}$, of these standards is $6 \mathrm{~m}^{2} \mathrm{~g}^{-1}$ at $550 \mathrm{~nm}$. While this represents properly the light absorption, the derived mass of black carbon will equal the true mass of black carbon on our sample filters only if $\beta_{\mathrm{abs}}$ of the sample aerosol $\mathrm{BC}$ is also $6 \mathrm{~m}^{2} \mathrm{~g}^{-1}$. The survey of Bond and Bergstrom (2006) concludes that $\beta_{\mathrm{abs}}$ is somewhat higher than this $\left(7.5 \pm 1.2 \mathrm{~m}^{2} \mathrm{~g}^{-1}\right.$ at $\left.550 \mathrm{~nm}\right)$ for aged atmospheric BC. If $\beta_{\text {abs }}$ of the snow BC is in fact, e.g., $7.5 \mathrm{~m}^{2} \mathrm{~g}^{-1}$ rather than $6 \mathrm{~m}^{2} \mathrm{~g}^{-1}$ the derived values of $C_{\mathrm{BC}}^{\max }, C_{\mathrm{BC}}^{\mathrm{est}}$, and $C_{B C}^{\text {equiv }}$ will be biased high by $\sim 20 \%$. The derived value of $f_{\text {non }}^{\text {est }}$ would consequently be biased low, but by less than the high bias in the $\mathrm{BC}$ concentrations since the fraction of absorption by non-BC constituents is much higher at shorter wavelengths $(<600 \mathrm{~nm})$ than at the wavelengths where BC concentration is quantified $(650-700 \mathrm{~nm})$. Consequently, the bias in $f_{\text {nonBC }}^{\text {est }}$ due to this source of uncertainty will be lower for samples of higher $\AA_{\text {tot }}$.

As discussed in Sect. 3.3, we use assumed values of the absorption Ångstrom exponent (quantified for 450-600 nm) for BC $\left(\AA_{\mathrm{BC}}\right)$ and non-BC $\left(\AA_{\text {nonBC }}\right)$ light-absorbing aerosol in our derivation of $C_{\mathrm{BC}}^{\text {est }}$ and $f_{\text {nonBC }}^{\text {est }}$. We have chosen to use values of $\AA_{\mathrm{BC}}=1.0$ and $\AA_{\text {nonBC }}=5.0$ based on previous studies of these quantities (Sect. 3.3). Here we assess how $C_{\mathrm{BC}}^{\text {est }}$ and $f_{\text {nonBC }}^{\text {est }}$ are affected if in fact $\AA_{\mathrm{BC}}$ and $\AA_{\text {nonBC }}$ differ from these assumed values.

For a lower bound on $\AA_{\mathrm{BC}}$ we use 0.8 , consistent with lowend values from both observations (Kirchstetter et al., 2004; Clarke et al., 2007) and theoretical studies (Gyawali et al., 2009; Schnaiter et al., 2005; Lack and Cappa, 2010). Lack and Cappa (2010) explore the theoretically-possible range of $\AA_{\text {BC }}$ (calculated 380-750 nm) for BC cores coated with both clear and light-absorbing (brown carbon) coatings and find it can be as low as 0.5 or as high as 1.6 for realistic atmospheric aerosol (regimes 1-3 in their Fig. 8a). Adjusting from their $\AA(380-750 \mathrm{~nm})$ to $\AA(450-600 \mathrm{~nm})$ shifts this to $\sim 0.8<\AA_{\mathrm{BC}}<1.9$ (their Fig. $8 \mathrm{~b}$ ). Thus, we adopt this range as the lower and upper bounds in our uncertainty analysis.

Non-BC light absorption may be due to a range of organic substances, either from combustion or soil, or due to mineral dust. $\AA$ for mineral dust has generally been in the range 2-3 (e.g. Fialho et al., 2006; Alfaro et al., 2004; Bergstrom et al., 2007), but it is not well-constrained. In any case, chemical analysis of our samples indicates that mineral dust is not responsible for a significant fraction of light absorption (Hegg et al., 2010), so we will concern ourselves instead with constraining $\AA_{\text {nonBC }}$ for organics. However, if this method is to be applied to snow samples laden with mineral dust the values of $\AA_{\text {nonBC }}$ used here should be adjusted accordingly. Here we have liberally set the bounds of $3.5 \leq \AA_{\text {nonBC }} \leq$ 7.0. We base these choices on Yang et al. (2009) who find $\AA \approx 3.5$ for brown carbon; Shapiro et al. (2009), whose labgenerated light-absorbing organics have $\AA \sim 6$ (calculated from their Fig. 1b); and Hoffer et al. (2006), who found that that HULIS (HUmic-LIke Substances) have $\AA$ of $6.4-$ 6.8. These bounds also encompass values measured in other studies (e.g. Sun et al., 2007; Roden et al., 2005), which have isolated $\AA$ of light-absorbing organic aerosol components, though higher values have sometimes been observed (e.g., Chen and Bond (2010) found that combustion-based light-absorbing OC can in some cases have $\AA>10$ ).

Figure 16 shows the absolute error in $C_{\mathrm{BC}}^{\text {est }}$ (for $C_{\mathrm{BC}}^{\text {est }}=$ $10 \mathrm{ng} \mathrm{g}^{-1}$ ) and the range in derived $f_{\text {nonBC }}^{\text {est }}$ if the true values of the absorption Angstrom exponent are at the low end $\left(\AA_{\mathrm{BC}}=0.8, \AA_{\text {nonBC }}=3.5\right)$ or the high end $\left(\AA_{\mathrm{BC}}=1.9\right.$, $\left.\AA_{\text {nonBC }}=7.0\right)$. While the potential errors are large for cases of high $\AA_{\text {tot }}$, almost all of our samples have $\AA_{\text {tot }}<2.8$ (as shown in the histogram of Fig. 16a), where the potential high bias in $C_{\mathrm{BC}}^{\text {est }}$ is at most a factor of two. For $\AA_{\text {tot }}<2.0$, the error in $C_{\mathrm{BC}}^{\mathrm{est}}$ is $<25 \%\left(10 \pm 2.5 \mathrm{ng} \mathrm{g}^{-1}\right)$. The relative error in $f_{\text {nonBC }}^{\text {est }}\left(\right.$ Fig. 16b) is less than the error in $C_{\mathrm{BC}}^{\text {est }}$ for larger values of $\AA_{\text {tot }}$, because of the larger fraction of non-BC vs. BC light absorption at shorter wavelengths. Physically impossible values of $C_{\mathrm{BC}}^{\text {est }}$ and $f_{\text {nonBC }}^{\text {est }}$ result when the measured value of $\AA_{\text {tot }}$ is either less than $\AA_{\mathrm{BC}}$ or greater than $\AA_{\text {nonBC }}$, forcing $C_{\mathrm{BC}}^{\text {est }}<0$ and/or $f_{\text {nonBC }}^{\text {est }}$ either $<0 \%$ or $>100 \%$. This highlights the fact that $\AA_{\mathrm{BC}}$ and $\AA_{\text {nonBC }}$ are likely well within the bounds we have set in Fig. 16.

Finally, we note that a small error in $f_{\text {nonBC }}^{\text {est }}$ results from the assumption that the absorption coefficient of lightabsorbing constituents is linear with wavelength in $\log \tau-\log$ $\lambda$ space. In fact it deviates from this somewhat so that, for example, while $f_{\text {nonBC }}^{\text {est }}$ should be $0 \%$ for the case of $\AA_{\text {tot }}=1.0$ and $\AA_{\mathrm{BC}}=1.0$, it is in fact $\sim 5 \%$ (Fig. 16). This results from the actual wavelength-dependence of absorption being somewhat steeper at shorter wavelengths than at longer wavelength (450-600 nm), where $\AA_{\text {tot }}$ is calculated.

In sum, all of our derived variables have an instrumental uncertainty of $\leq 11 \%$. The concentration-related values, $C_{\mathrm{BC}}^{\max }, C_{\mathrm{BC}}^{\mathrm{est}}$ and $C_{\mathrm{BC}}^{\mathrm{e} q u i v}$ also have possible biases of up to 

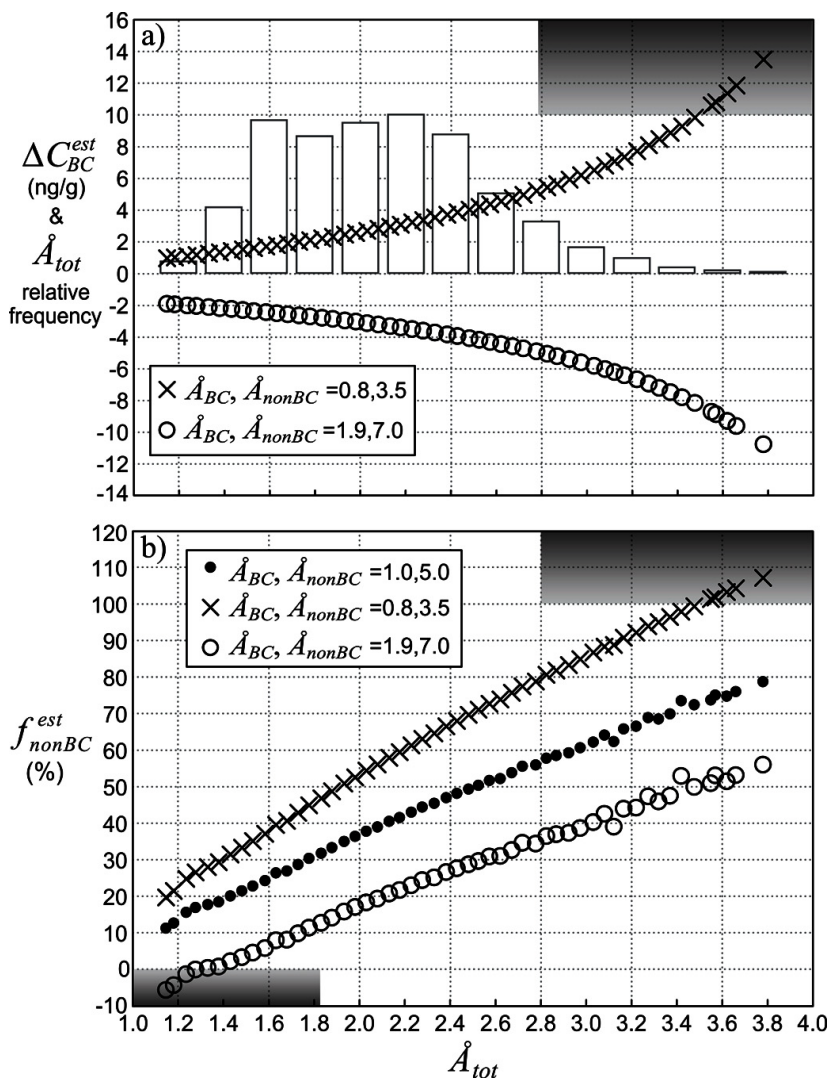

Fig. 16. Sensitivity of derived values to uncertainty in the assumed absorption Angstrom exponents for $\mathrm{BC}$ and non-BC. The values used in the analysis were $\AA_{\mathrm{BC}}=1.0$ and $\AA_{\text {nonBC }}=5.0$. (a) Error in $C_{\mathrm{BC}}^{\text {est }}\left(\mathrm{ng} \mathrm{g}^{-1}\right)$ as a function of the measured absorption Ångstrom exponent from the filter, $\AA_{\text {tot }}$, when $C_{\mathrm{BC}}^{\text {est }}=10 \mathrm{ng} \mathrm{g}^{-1}$ and the true values of $\AA_{\mathrm{BC}}$ and $\AA_{\text {nonBC }}$ are lower (0.8 and 3.8, respectively) or higher (1.2 and 7.0, respectively) than the values assumed in the analysis. Also shown is a histogram of the relative frequency of occurrence of $\AA_{\text {tot }}$ in our sample data set. (b) Inferred percent of absorption due to non-BC absorbers, as obtained using three different sets of assumptions for absorption Ångstroms. Values shown in both frames are calculated from all the samples included in Sect. 5, averaged into bins of $\AA_{\text {tot }}$. Shaded regions indicate values that are physically impossible $\left(C_{\mathrm{BC}}^{\mathrm{est}}<0, f_{\text {nonBC }}^{\text {est }}<0 \%, f_{\text {nonBC }}^{\text {est }}>100 \%\right)$.

$\pm 15 \%$ due to the under-catch correction, and the samples from West Russia and sub-arctic Canada having an additional possible bias of up to $\pm 20 \%$ via the correction for losses of aerosol to plastic flakes in the collection bags. If we are using calibration standards with an inappropriate BC mass absorption coefficient $\left(6 \mathrm{~m}^{2} \mathrm{~g}^{-1}\right)$ there will also be a bias in our derived values of $C_{\mathrm{BC}}^{\max }, C_{\mathrm{BC}}^{\text {est }}$ and $C_{\mathrm{BC}}^{\mathrm{equiv}}$. If Bond and Bergstrom's (2006) study is correct, and we should be using standards with MAC $=7.5 \mathrm{~m}^{2} \mathrm{~g}^{-1}$, our resulting BC concentrations are biased $\sim 20 \%$ high, but it remains to be determined if snow $\mathrm{BC}$ has the same mass absorption efficiency as atmospheric BC. As shown in Fig. 16, $C_{\mathrm{BC}}^{\text {est }}$ and $f_{\text {nonBC }}^{\text {est }}$ have an additional source of uncertainty stemming from un- certainty in the appropriate values of $\AA_{\mathrm{BC}}$ and/or $\AA_{\text {nonBC }}$ for the sampled aerosol, with the magnitude of the uncertainty a function of the error in assumed Ångstroms and of $\AA_{\text {tot }}$. Using very liberal estimates of this potential source of error we show that this produces uncertainties of $<50 \%$ for almost all of the samples in this study. We conclude from this that the ISSW spectrophotometric method for measuring snow light-absorbing aerosol in snow would benefit greatly from improved understanding of (a) the mass absorption coefficient of snow BC, determined for a range of snow BC sources and (b) the spectral properties of light absorption by non-BC aerosols in snow.

\section{Has the Arctic snow become cleaner since 1984?}

From two ice cores in West Greenland, McConnell et al. (2007) showed that soot pollution from North America peaked in 1900-1910 due to coal burning, with BC values $\sim 10 \mathrm{ng} \mathrm{g}^{-1}$, then declined rapidly to $\sim 3 \mathrm{ng} \mathrm{g}^{-1}$ by 1950 . The BC content in the ice continued to decline slowly, and by 2000 had dropped to equal the preindustrial value of $1-$ $2 \mathrm{ng} \mathrm{g}^{-1}$. Snow on the Greenland Ice Sheet is the cleanest snow of the Arctic, and these values represent the free tropospheric BC content at an elevation of $\sim 2600 \mathrm{~m}$, so it is of interest to examine evidence from lower-elevation sites where only seasonal snow, rather than ice cores, is available.

$\mathrm{BC}$ in the near-surface atmosphere has been monitored continuously since 1989 at Alert on Ellesmere Island $\left(82.4^{\circ} \mathrm{N}, 62.3^{\circ} \mathrm{W}, 210 \mathrm{~m}\right)$ (Gong et al., 2010), and at Barrow, Alaska (Sharma et al., 2006), and since 1998 at the Zeppelin station above $\mathrm{Ny}-\mathrm{A} l e s u n d ~\left(79^{\circ} \mathrm{N}, 12^{\circ} \mathrm{E}, 474 \mathrm{~m}\right)$ (Eleftheriadis et al., 2009; Forsström et al., 2009). All three locations document the seasonal cycle with $\mathrm{BC}$ concentrations peaking in winter, and all three show a multi-year decline of the wintertime peak. At Alert, the wintertime peaks for 2006-2008 are about one-third of their value in 1989-1991. One suggested contributor to the decline is the reduced emissions from fossil-fuel burning in Russia and Eastern Europe since the breakup of the Soviet Union (Fig. 8 of Sharma et al., 2004). We might therefore expect to see a corresponding decline in the $\mathrm{BC}$ content of snow. Table 9 compares our regional medians for 2005-2009 to those from CN85 for 1983-1984. There is a suggestion of a decline in the values for Canada, Alaska, and Svalbard. However, the CN85 data were based on 60 samples compared to our 1200 . Given the patchiness evident in our side by side samples discussed earlier, a quantitative evaluation of these differences is difficult. Moreover, we cannot definitively say that the two results differ significantly, because part of the difference is probably caused by the different photometric methods used. CN85 also used an integrating-plate photometer (instead of the integrating sandwich) to analyze their nuclepore filters, and in that method the scattering by particles on the filter can reduce transmittance in a way that would be erroneously attributed 
Table 9. A comparison of median estimated BC concentrations in snow $\left(\mathrm{ng} \mathrm{g}^{-1}\right)$ for regions around the Arctic, from a previous study in the 1980 's and from this work.

\begin{tabular}{lcr}
\hline & $\begin{array}{r}\text { Clarke and Noone (1985), } \\
60 \text { samples 1983-1984 }\end{array}$ & $\begin{array}{r}\text { This work, } \sim 1200 \text { samples, } \\
1998 \text { and 2005-2009 }\end{array}$ \\
\hline Greenland & 2 & 4 (spring), 1 (summer) \\
Canada & 21 & 8 (Arctic), 15 (sub-Arctic) \\
Alaska & 15 & 9 \\
Svalbard & 22 & 14 \\
Russia & & $\sim 20$ \\
Arctic Ocean & & 7 \\
\hline
\end{tabular}

to absorption (Clarke et al., 1982). We can not quantitatively assess the resulting high bias and therefore can not determine to what degree the decreases shown in Table 9 reflect real decreases in snow BC concentrations versus a change in measurement methods. However, we can at least conclude that concentrations in the areas sampled have not increased.

Table 9 does not list a value from $\mathrm{CN} 85$ for the Arctic Ocean. CN85's Table 1 did list eight snow samples from Fram Strait between Greenland and Svalbard, on the periphery of the Arctic Ocean, but we are reluctant to compare them with our values from the central Arctic. The eight samples exhibited enormous spread, with values $0.6,5,14$, $15,50,51,60$, and $76 \mathrm{ng} \mathrm{g}^{-1}$. The median of these values, $32 \mathrm{ng} \mathrm{g}^{-1}$, was offered in Table S3 of Hegg et al. (2009) to represent $\mathrm{CN} 85$ for the Arctic Ocean, but that was a mistake. CN85 had pointed out (bottom of their page 2050) that two of the filters with high values contained large particles $(\sim 50 \mu \mathrm{m})$, which almost certainly originated from emissions by the ship, which was $200 \mathrm{~km}$ distant from the nearest land (Svalbard). If we omit those samples, the revised median is $14 \mathrm{ng} \mathrm{g}^{-1}$, closer to our modern Arctic Ocean median of $7 \mathrm{ng} \mathrm{g}^{-1}$. But we again remind the reader that Fram Strait is on the periphery of the Arctic Ocean; it would be more appropriate to compare its values to those of nearby Svalbard $\left(13 \mathrm{ng} \mathrm{g}^{-1}\right)$.

The fact that the BC content of Arctic snow appears no higher now than in 1984, and that the Arctic atmosphere is now cleaner than in 1989, causes us to doubt that BC in Arctic snow has contributed to the rapid decline of Arctic sea ice in recent years. However, increasing BC in midlatitude snow may have contributed indirectly, by enhancing warm-air advection into the Arctic (Flanner et al., 2009).

\section{Other influences on albedo of Arctic snow}

It is important to point out that variation in impurity content of snow is not the major cause of surface-albedo variation in the Arctic spring. The major variable affecting snow albedo is the effective grain size (Wiscombe and Warren, 1980), which for a nonspherical snow grain is proportional to the volume-to-area ratio (Grenfell and Warren, 1999). The ef- fective grain radius for new snow is $50-100 \mu \mathrm{m}$, and for old melting snow it is $\sim 1000 \mu \mathrm{m}$; the corresponding broadband albedo reduction in pure deep snow is $\sim 0.12$ (Fig. 1 of Warren and Wiscombe, 1985). This difference is much larger than the albedo difference caused by the typical concentrations of impurities we find in Arctic snow. These two influences (grain size and $\mathrm{BC}$ content) also interact: the change in albedo for a given concentration of $\mathrm{BC}$ will be greater for larger grained snow than for smaller grained snow (e.g. for $50 \mathrm{ng} \mathrm{g}^{-1}$ of BC, $\Delta$ albedo at $470 \mathrm{~nm}$ is 0.03 for snow with $100 \mu \mathrm{m}$ grain radius but 0.08 for snow with $1000 \mu \mathrm{m}$ grain radius) (Fig. 2 of Warren and Wiscombe, 1985).

A second major influence on surface albedo in the Arctic is snow depth. At $500 \mathrm{~nm}$, the e-folding depth for clean Antarctic snow was $25 \mathrm{~cm}$ (Figs. 3 and 4 of Warren et al., 2006); for snow on Arctic sea ice with some soot pollution it was $6 \mathrm{~cm}$ for dry compact snow and $12 \mathrm{~cm}$ for melting snow (Grenfell and Maykut, 1977). Schwerdtfeger and Weller (1977); (reproduced as Fig. 8 of Warren, 1982) found broadband transmittance of $1 \%$ at 1-m depth in clean Antarctic snow. Thus, Arctic snow, with maximum thickness in spring typically $30 \mathrm{~cm}$ or less, is thus often insufficiently thick to hide the underlying surface (e.g., Fig. 13). Because the plot of albedo versus optical depth is nonlinear, concave downward, the average albedo for a snowfield of variable thickness is lower than that of a snowfield of uniform thickness with the same total mass of snow. A climate model that assigns a uniform snow depth to a grid box will compute an albedo that is higher than the true area-averaged albedo. Climate models do have diverse parameterizations for sub-grid snow-covered area as a function of average snow depth (Liston, 2004), but most do not represent the variability of snow depth within the snow-covered area.

The thinness of Arctic snow also means that BC content cannot be obtained from remote sensing without independent knowledge of snow depth. This is because the spectral signature of sooty snow (Fig. 7 of Warren and Wiscombe, 1980 ) is nearly identical to that of thin snow (Fig. 13 of Wiscombe and Warren, 1980), with both producing reduced albedo compared to pure deep snow at visible wavelengths, but no change at near-infrared wavelengths. 


\section{Conclusions}

The present survey has provided information about the geographical and seasonal variations of $\mathrm{BC}$ and other LAA in Arctic snow, confirming that impurities in snow are significant for the surface energy budget of the Arctic. Concentrations are highest and most variable in the eastern Arctic (Scandinavia, Russia and Svalbard) and lower and less variable in the western Arctic (Canada and Alaska), with intermediate values for snow-covered sea ice and in bare sea ice on the Arctic Ocean. This is qualitatively consistent with GCM predictions (e.g. Fig. 5 of Flanner et al., 2007); a quantitative comparison is needed and can now be done with the available data.

We show that $\sim 20-50 \%$ of the light absorption by particles in the snowpack is by non-black-carbon constituents, such as brown carbon and dust. The chemical fingerprint associated with the LAA (Hegg et al., 2009, 2010) indicates that brown carbon is the source of most of the non-BC light absorption and that the source of most Arctic BC is biomass or biofuel burning for Canada and Western Russia throughout the winter and spring and for Greenland in winter and spring. It shows that emissions from fossil-fuel combustion make a significant contribution in summertime deposition to Greenland, to the springtime high-latitude Arctic Ocean and in some locations in western Russia (Hegg et al., 2009, 2010). The absorption Ångstrom exponents of particulate snow impurities presented here are consistent with these findings. Chemical analysis of snow samples from Norway and Svalbard has not yet been done, but the absorption Ångstrom exponents of these samples indicates a larger role of fossilfuel aerosol than at the other sites.

Although our survey is far more comprehensive than the earlier survey of $\mathrm{CN} 85$, there is more work to be done. More measurements in Scandinavia and western Russia would be desirable, because snow in those regions is predicted by models (Flanner et al., 2007; Koch et al., 2009) to have the highest $\mathrm{BC}$ concentrations of the Arctic. It would also be valuable to expand the survey to midlatitudes, where the snow is closer to sources of pollution and is exposed to more intense sunlight. The regions where radiative forcing could be large are the vast treeless areas on the Great Plains of North America, and on the steppes of Asia: Mongolia, Xinjiang, and Kazakhstan.

Several process studies are needed. Monitoring of the snowmelt process at several locations is needed to examine the vertical redistribution of BC (and non-BC LAA) in snow. Coincident measurements of $\mathrm{BC}$ in air and in falling snow would provide information about the scavenging process. Controlled experiments, probably on artificial snowpacks, are needed to verify the radiative-transfer modeling of albedo reduction. There are indications that estimates of $\mathrm{BC}$ by our filter method are substantially higher than those inferred from the thermo-optical method; a thorough comparison of the ISSW, thermo-optical and SP2 methods for measuring $\mathrm{BC} / \mathrm{EC}$ would be valuable. Finally, while the $\mathrm{BC}$ concentrations reported here are large enough to significantly alter the snow albedo, Arctic snow is often thin enough that the surface albedo is influenced by the underlying surface and by non-snow-covered vegetation (Sturm et al., 2005). In many areas the surface albedo may therefore be affected more by variations in snow depth than by impurities. Also, while we avoided sampling snow and sea ice that was obviously contaminated with local soil, areas with thin snow or near deserts or in some sea ice zones, soil and sediment may dominate light absorption in the snowpack.

\section{Appendix A}

\section{Abbreviations}

\begin{tabular}{ll}
\hline AARI & Arctic and Antarctic Institute (St. Petersburg) \\
APLIS & Applied Physics Laboratory Ice Station \\
AWS & Automatic weather station \\
CRREL & Cold Regions Research and Engineering Laboratory \\
CU & University of Colorado \\
GEUS & Geological Survey of Denmark and Greenland \\
GIS & Greenland Ice Sheet \\
HOTRAX & Healy-Oden Trans-Arctic Expedition \\
KPCL & Kronprinz Christians Land (northeast Greenland) \\
NPEO & North Pole Environmental Observatory \\
NPI & Norwegian Polar Institute \\
SEDNA & Sea ice Experiment - Dynamic Nature of the Arctic \\
SHEBA & Surface Heat Budget of the Arctic Ocean \\
UAF & University of Alaska at Fairbanks \\
UCal & University of Calgary \\
UDel & University of Delaware \\
UH & University of Hawaii \\
UId & University of Idaho \\
UK & University of København \\
UMan & University of Manitoba \\
UNIS & University of Svalbard \\
UVic & University of Victoria \\
UW & University of Washington \\
\hline
\end{tabular}

Acknowledgements. We acknowledge the major contribution from Matthew Sturm and his colleagues for collecting snow on a long transect across Canada. We also acknowledge the repeated contributions over several years from Konrad Steffen and his colleagues for collecting snow at numerous sites in Greenland. In the Arctic Ocean, Mike Steele, James Morison, and Andy Heiberg obtained snow samples from the North Pole region. We thank Cathleen Geiger, Jacqueline Richter-Menge, Eddy Carmack and Kristina Brown for their dedicated efforts at detailed sampling in the Beaufort Sea.

The Russian expeditions were organized in collaboration with Vladimir Radionov and Victor Boyarsky; Tom Quinn (CH2M Hill) facilitated the logistics. Vladimir Makarov and Lyudmila Boytsova provided supplies and organized transport for us in the vicinity of Yakutsk. Sergei and Galina Zimov provided hospitality and advice on sampling locations in the Cherskiy region. Dmitriy Kozelov, Vitaliy Keller, and Sergey Khrushchyov of the Hydrometeorological Service in Pevek facilitated our snow sampling in Chukotka. Stanislav Kogan, Valery Ippolitov, Mikhail Lamakin, 
and Stephen Hudson assisted with the fieldwork. Alfred Helmig and Thomas Ernsdorf (University of Trier; Transdrift XIII expedition) expanded our survey by collecting samples near the Laptev Sea Polynya.

The success of the expedition to Canadian Arctic islands was due to the enthusiasm and piloting expertise of Gordon Johnson and Tim Sangster. We also acknowledge support from the Polar Continental Shelf Project (PSCP) at Resolute, and Tom Quinn for logistical planning. We thank the government of Nunavut for approving our application to undertake this expedition.

Glenn Sheehan and the staff of the Barrow Arctic Science Corporation (BASC) supported our work in Alaska. Drew Abbott and Silver Williams hosted us at Raven Station on the Greenland Ice Sheet in 2007, and Lou and Mark Albershardt in 2008. We thank Carl-Egede Bøggild for inviting us to his field camp in northeast Greenland in 2006.

We thank Sebastian Gerland of the Norwegian Polar Institute (NPI) for inviting us to Svalbard. Working in the field and laboratory with him and his colleagues (Christina Pedersen and Sanja Forsström) has advanced our understanding of BC measurement methods and improved our methods for measuring spectral albedo. Sanja Forsström organized the melting experiment at Fjellheisen near Troms $\varnothing$. Jane Carlsen collected falling snow from each snowfall event for two months at $\mathrm{Ny}$-Ålesund.

We acknowledge numerous additional volunteers who collected snow for us: Matt Nolan in Alaska; Shawn Marshall, Von Walden, and David Barber in Canada; Ron Sletten, Mike Town, and Lora Koenig in Greenland; Sebastian Simonsen near Svalbard; Annie Aggens in the Arctic Ocean; and Hyun-Seung Kim and Kristel Guimara in Washington and New York. Angel Adames and Hugo Froyland operated the laboratory spectrophotometer to measure our filters. Discussions with Tami Bond, Ross Edwards, Mark Flanner, Dorothy Koch, Joe McConnell, and Charlie Zender have been valuable. We thank Dean Hegg for his consistent interest and many illuminating discussions. Helpful comments on the manuscript were provided by Daniel Lack, Florent Domine and one anonymous reviewer.

We thank James Hansen (NASA-GISS) and Ellen Baum (Clean Air Task Force) for encouraging us to undertake this project, and Bill Wiseman (NSF) for his support. Financial support was provided by the Clean Air Task Force, the Oak Foundation, and the US National Science Foundation under grant number ARC-06-12636.

Editedt by: T. Kirchstetter

\section{References}

Aleksandrov, Ye. I., Bryazgin, N. N., Førland, E. J., Radionov, V. F., and Svyashchennikov, P. N.: Seasonal, interannual and longterm variability of precipitation and snow depth in the region of the Barents and Kara seas, Polar Res., 24, 69-85, 2005.

Alfaro, S. C., Lafon, S., Rajot, L., Formenti, P., Gaudichet, A., and Maille, M.: Iron oxides and light absorption by pure desert dust: An experimental study, J. Geophys. Res., 109, D08208, doi:10.1029/2003JD004374, 2004.

Bergstrom, R. W., Russell, P. B., and Hignett, P.: Wavelength dependence of the absorption of black carbon particles: Predictions and results from the TARFOX experiment and implications for the aerosol single scattering albedo, J. Atmos. Sci., 59, 567-577, 2002.

Bergstrom, R. W., Pilewskie, P., Russell, P. B., Redemann, J., Bond, T. C., Quinn, P. K., and Sierau, B.: Spectral absorption properties of atmospheric aerosols, Atmos. Chem. Phys., 7, 5937-5943, doi:10.5194/acp-7-5937-2007, 2007.

Bøggild, C. E., Brandt, R. E., Brown, K. J., and Warren, S. G.: The ablation zone in northeast Greenland: Ice types, albedos, and impurities, J. Glaciol., 56, 101-113, 2010.

Bond, T.: Spectral dependence of visible light absorption by carbonaceous particles emitted from coal combustion, Geophys. Res. Lett., 28, 4075-4078, 2001.

Bond, T. C. and Bergstrom, R. W.: Light absorption by carbonaceous particles: an investigative review, Aerosol Sci. Tech., 40, 27-67, 2006.

Bond, T. C., Bussemer, M., Wehner, B., Keller, S., Charlson, R. J., and Heintzenberg, J.: Light absorption by primary particle emissions from a lignite burning plant, Environ. Sci. Technol., 33, 3887-3891, 1999.

Bond, T. C., Streets, D. G., Yarber, K. F., Nelson, S. M., Woo, J. H., and Klimont, Z.: A technology-based global inventory of black and organic carbon emissions from combustion, J. Geophys. Res., 109, D14203, doi:10.1029/2003JD003697, 2004.

Boparai, P., Lee, J., and Bond, T. C.: Revisiting thermaloptical analyses of carbonaceous aerosol using a physical model, Aerosol Sci. Tech., 42, 930-948, 2008.

Brandt, R. E., Warren, S. G., and Clarke, A. D.: A controlled snowmaking experiment relating black-carbon content to reduction of snow albedo, J. Geophys. Res., submitted, 2010.

Cachier, H. and Pertuisot, M. H.: Particulate carbon in Arctic ice, Analusis Magazine, 22, 34-37, 1994.

Cess, R. D.: Arctic aerosols: Model estimates of interactive influences upon the surface-atmosphere clear-sky radiation budget, Atmos. Environ., 17, 2555-2564, 1983.

Chen, Y. and Bond, T. C.: Light absorption by organic carbon from wood combustion, Atmos. Chem. Phys., 10, 1773-1787, doi:10.5194/acp-10-1773-2010, 2010.

Chýlek, P., Johnson, B., and Wu, H.: Black carbon concentration in a Greenland Dye-3 ice core, Geophys. Res. Lett., 19, 1951-1953, 1992.

Chýlek, P., Johnson, B., Damiano, P. A., Taylor, K. C., and Clement, P.: Biomass burning record and black carbon in the GISP2 ice core, Geophys. Res. Lett., 22, 89-92, 1995.

Clarke, A. D.: Integrating sandwich: a new method of measurement of the light absorption coefficient for atmospheric particles, Appl. Optics, 21, 3011-3020, 1982.

Clarke, A. D. and Noone, K. J.: Soot in the Arctic snowpack: A cause for perturbations in radiative transfer, Atmos. Environ., 19, 2045-2053, 1985.

Clarke, A. D., Noone, K. J., Heintzenberg, J., Warren, S. G., and Covert, D. S.: Aerosol light absorption measurement techniques: analysis and intercomparisons, Atmos. Environ., 21, 1455-1465, 1987.

Clarke, A. D., Shinozuka, Y., Kapustin, V. N., Howell, S., Huebert, B., Doherty, S., Anderson, T., Covert, D., Anderson, J., Hua, X., Moore II, K. G., McNaughton, C., Carmichael, G., and Weber, R.: Size distributions and mixtures of dust and black carbon aerosol in Asian outflow: Physiochem- 
istry and optical properties, J. Geophys. Res., 109, D15S09, doi:10.1029/2003JD004378, 2004.

Clarke, A., McNaughton, C., Kapustin, V., Shinozuka, Y., Howell, S., Dibb, J., Zhou, J., Anderson, B., Brekhovskikh, V., Turner, H., and Pinkerton, M.: Biomass burning and pollution aerosol over North America: Organic components and their influence on spectral optical properties and humidification response, J. Geophys. Res., 112, D12S18, doi:10.1029/2006JD007777, 2007.

Cross, E. S., Onasch, T. B., Ahern, A., Wrobel, W., Slowik, J. G., Olfert, J., Lack, D. A., Massoli, P., Cappa, C. D., Schwartz, J., Spackman, R., Fahey, D. W., Sedlacek, A., Trimborn, A., Jayne, J. T., Freedman, A., Williams, L. R., Ng, N. L., Mazzoleni, C., Dubey, M., Brem, B., Kok, G., Subramanian, R., Freitag, S. Clarke, A., Thornhill, D., Marr, L., Kolb, C. E., Worsnop, D. R., and Davidovits P.: Soot particle studies - instrument intercomparison - project overview, Aerosol Sci. Technol., 44(8), 592$611,2010$.

Eicken, H.: The role of Arctic sea ice in transporting and cycling terrestrial organic matter, in: The Organic Carbon Cycle in the Arctic Ocean: Present and Past, edited by: Stein, R. and Macdonald, R. W., Berlin: Springer-Verlag, 45-53, 2003.

Eicken, H., Gradinger, R., Graves, A., Mahoney, A., and Rigor, I.: Sediment transport by sea ice in the Chukchi and Beaufort Seas: Increasing importance due to changing ice conditions?, DeepSea Res. II, 52, 3281-3302, 2005.

Eleftheriadis, K., Vratolis, S., and Nyeki, S.: Aerosol black carbon in the European Arctic: measurements at Zeppelin station, Ny-Ålesund, Svalbard from 1998-2007, Geophys. Res. Lett., 36, L02809, doi:10.1029/2008GL035741, 2009.

Fialho, P., Hansen, A. D. A., and Honrath, R. E.: Absorption coefficients by aerosols in remote areas: A new approach to decouple dust and black carbon absorption coefficients using seven wavelength Aethalometer data, J. Aerosol Sci., 36(2), 267-282, 2005.

Fialho, P., Freitas, M. C., Barata, F., Vieira, B., Hansen, A. D. A., and Honrath, R. E.: The Aethalometer calibration and determination of iron concentration in dust aerosols, J. Aerosol Sci., 37(11), 1497-1506, 2006.

Flanner, M. G. and Zender, C. S.: Linking snowpack microphysics and albedo evolution, J. Geophys. Res., 111, D12208, doi:10.1029/2005JD006834, 2006.

Flanner, M. G., Zender, C. S., Randerson, J. T., and Rasch, P. J.: Present-day climate forcing and response from black carbon in snow, J. Geophys. Res., 112, D11202, doi:10.1029/2006JD008003, 2007.

Flanner, M. G., Zender, C. S., Hess, P. G., Mahowald, N. M., Painter, T. H., Ramanathan, V., and Rasch, P. J.: Springtime warming and reduced snow cover from carbonaceous particles, Atmos. Chem. Phys., 9, 2481-2497, doi:10.5194/acp-9-24812009, 2009.

Forsström, S., Ström, J., Pedersen, C. A., Isaksson, E., and Gerland, S.: Elemental carbon distribution in Svalbard snow, J. Geophys. Res., 114, D19112, doi:10.1029/2008JD011480, 2009.

Frey, K., Eicken, H., Perovich, D. K., Grenfell, T. C., Light, B., Shapiro, L. H., and Stierle, A. P.: Heat budget and decay of clean and sediment-laden sea ice off the northern coast of Alaska, POAC'01 Conference, Ottawa, August, 2001.

Gong, S. L., Zhao, T. L., Sharma, S., Toom-Sauntry, D., Lavoue, D., Zhang, X. B., Leaitch, R., and Barrie, L. A.: Identification of trends and inter-annual variability of sulphate and black carbon in the Canadian High Arctic: 1981 to 2007, J. Geophys. Res., 115, D07305, doi:10.1029/2009JD012943, 2010.

Grenfell, T. C. and Maykut, G. A.: The optical properties of ice and snow in the Arctic Basin, J. Glaciol., 18, 445-463, 1977.

Grenfell, T. C. and Perovich, D. K.: The seasonal and spatial evolution of albedo in a snow-ice-land-ocean environment, J. Geophys. Res., 109(C1), C01001,doi: 10.1029/2003JC001866, 2004.

Grenfell, T. C. and Warren, S. G.: Representation of a nonspherical ice particle by a collection of independent spheres for scattering and absorption of radiation, J. Geophys. Res., 104, 31697 31709, 1999.

Grenfell, T. C., Warren, S. G., and Mullen, P. C.: Reflection of solar radiation by the Antarctic snow surface at ultraviolet, visible, and near-infrared wavelengths, J. Geophys. Res., 99, 18669-18684, 1994.

Grenfell, T. C., Light, B., and Sturm, M.: Spatial distribution and radiative effects of soot in the snow and sea ice during the SHEBA experiment, J. Geophys. Res., 107(C10), 8032, doi:10.1029/2000JC000414, 2002.

Grenfell, T. C., Warren, S. G., Radionov, V. F., Makarov, V. N., and Zimov, S. A.: IPY expeditions to the Russian Arctic to survey light-absorbing carbon in snow, EOS, 90, 386-387, 2009.

Grenfell, T. C., Doherty, S. J., Clarke, A. D., and Warren, S. G.: Spectrophotometric determination of absorptive impurities in snow, Appl. Opt., in review, available at: http://www.atmos.washington.edu/ $\sim_{\text {sgw/PAPERS/ }}$ 2010_ISSW_Appl_Opt_submitted.pdf, 2010.

Gyawali, M., Arnott, W. P., Lewis, K., and Moosmüller, H.: In situ aerosol optics in Reno, NV, USA during and after the summer 2008 California wildfires and the influence of absorbing and non-absorbing organic coatings on spectral light absorption, Atmos. Chem. Phys., 9, 8007-8015, doi:10.5194/acp-9-8007-2009, 2009.

Hagler, G. S. W., Bergin, M. H., Smith, E. A., and Dibb, J. E.: A summer time series of particulate carbon in the air and snow at Summit, Greenland, J. Geophys. Res., 112, D21309, doi:10.1029/2007JD008993, 2007a.

Hagler, G. S. W., Bergin, M. H., Smith, E. A., Dibb, J. E., Anderson, C., and Steig, E. J.: Particulate and water-soluble carbon measured in recent snow at Summit, Greenland, Geophys. Res. Lett., 34, L16505, doi:10.1029/2007GL030110, 2007 b.

Hansen, J. and Nazarenko, L.: Soot climate forcing via snow and ice albedos, Proc. Natl. Acad. Sci. USA, 101, 423-428, 2004.

Hansen, J., Sato, M., Ruedy, R., Nazarenko, L., Lacis, A., Schmidt, G. A., Russell, G., Aleinov, I., Bauer, M., Bauer, S., Bell, N., Cairns, B., Canuto, V., Chandler, M., Cheng, Y., Del Genio, A., Faluvegi, G., Fleming, E., Friend, A., Hall, T., Jackman, C., Kelley, M., Kiang, N., Koch, D., Lean, J., Lerner, J., Lo, K., Menon, S., Miller, R., Minnis, P., Novakov, T., Oinas, V., Perlwitz, Ja., Perlwitz, Ju., Rind, D., Romanou, A., Shindell, D., Stone, P., Sun, S., Tausnev, N., Thresher, D., Wielicki, B., Wong, T., Yao, M., and Zhang, S.: Efficacy of climate forcings, J. Geophys. Res., 110, D18104, doi:10.1029/2005JD005776, 2005.

Harder, S. L., Warren, S. G., Charlson, R. J., and Covert, D. S.: Filtering of air through snow as a mechanism for aerosol deposition to the Antarctic ice sheet, J. Geophys. Res., 101, 18729-18743, 1996.

Hegg, D. A., Warren, S. G., Grenfell, T. C., Doherty, S. J., Larson, 
T. V., and Clarke, A. D.: Source attribution of black carbon in arctic snow, Environ. Sci. Technol., 43, 4016-4021, 2009.

Hegg, Dean, A., Warren, Stephen G., Grenfell, Thomas C., Doherty, S. J., and Clarke, A. D.: Sources of light-absorbing aerosol in arctic snow and their seasonal variation, Atmos. Chem. Phys., 10, 10923-10938, doi:10.5194/acp-10-10923-2010, 2010.

Hoffer, A., Gelencsér, A., Guyon, P., Kiss, G., Schmid, O., Frank, G. P., Artaxo, P., and Andreae, M. O.: Optical properties of humic-like substances (HULIS) in biomass-burning aerosols, Atmos. Chem. Phys., 6, 3563-3570, doi:10.5194/acp-6-3563-2006, 2006.

Huang, J., Fu, Q., Zhang, W., Wang, X., Zhang, R., Ye, H., and Warren, S.: Dust and black carbon in seasonal snow across northern China, B. Am. Meteor. Soc., in press, 2011.

Ivanov, B.: Contamination of sea ice and related albedo estimates, Ice and Climate News (CliC International Project Office), 6, 1113, 2005.

Jacobson, M. Z.: Climate response of fossil fuel and biofuel soot, accounting for soot's feedback to snow and sea ice albedo and emissivity, J. Geophys. Res., 109, D21201, doi:10.1029/2004JD004945, 2004.

Kirchstetter, T. W., Novakov, T., and Hobbs, P. V.: Evidence that the spectral dependence of light absorption by aerosols is affected by organic carbon, J. Geophys. Res., 109, D21208, doi:10.1029/2004JD004999, 2004.

Koch, D. and Hansen, J.: Distant origins of Arctic black carbon: A Goddard Institute for Space Studies ModelE experiment, J. Geophys. Res., 110, D042404, doi:10.1029/2004JD005296, 2005.

Koch, D., Menon, S., DelGenio, A., Ruedy, R., Alienov, I., and Schmidt, G. A.: Distinguishing aerosol impacts on climate over the past century, J. Climate, 22, 2659-2677, doi:10.1175/2008JCLI2573.1, 2009.

Kopanev, I. D. and Lipovskaya, V. I.: Distribution of snow depth in the USSR, CRREL Draft Translation 687, Cold Regions Research and Engineering Laboratory, Hanover, NH, 15 pp., 1978.

LaChapelle, E. R.: Field Guide to Snow Crystals, University of Washington Press, Seattle, 1969.

Lack, D. A. and Cappa, C. D.: Impact of brown and clear carbon on light absorption enhancement, single scatter albedo and absorption wavelength dependence of black carbon, Atmos. Chem. Phys., 10, 4207-4220, doi:10.5194/acp-10-4207-2010, 2010.

Lafon, S., Sokolik, I. N., Rajot, J. L., Caquineau, S., and Gaudichet, A.: Characterization of iron oxides in mineral dust aerosols: Implications for light absorption, J. Geophys. Res., 111(D21), doi:10.1029/2005JD007016, 2006.

Linke, C., Möhler, O., Veres, A., Mohácsi, Á, Bozóki, Z., Szabó, G., and Schnaiter, M.: Optical properties and mineralogical composition of different Saharan mineral dust samples: a laboratory study, Atmos. Chem. Phys., 6, 3315-3323, doi:10.5194/acp-63315-2006, 2006.

Liston, G. E.: Representing subgrid snow cover heterogeneities in regional and global models, J. Climate, 17, 1381-1397, 2004.

Liston, G. E. and Sturm, M.: The role of winter sublimation in the Arctic moisture budget, Nord. Hydrol., 35, 325-334, 2004.

Lyapustin, A., Gatebe, C. K., Kahn, R., Brandt, R., Redemann, J., Russell, P., King, M. D., Pedersen, C. A., Gerland, S., Poudyal, R., Marshak, A., Wang, Y., Schaaf, C., Hall, D., and Kokhanovsky, A.: Analysis of snow bidirectional reflectance from ARCTAS Spring-2008 Campaign, Atmos. Chem. Phys., 10,
4359-4375, doi:10.5194/acp-10-4359-2010, 2010.

McConnell, J. R., Edwards, R., Kok, G. L., Flanner, M. G., Zender, C. S. Saltzman, E. S., Banta, J. R., Pasteris, D. R., Carter, M. M., and Kahl, J. D. W.: 20th century industrial black carbon emissions altered Arctic climate forcing, Science, 317, 1381-1384, doi:10.1126/science.1144856, 2007.

Meloni, D., di Sarra, A., Pace, G., and Monteleone, F.: Aerosol optical properties at Lampedusa (Central Mediterranean). 2. Determination of single scattering albedo at two wavelengths for different aerosol types, Atmos. Chem. Phys., 6, 715-727, doi:10.5194/acp-6-715-2006, 2006.

Millikan, R. C.: Optical properties of soot, J. Opt. Soc. Am., 51, 698-699, 1961.

Mollicone, D., Eva, H. D., and Achard F.: Human role in Russian wildfires, Nature, 440, 436-437, 2006.

Morison, J. H., Aagaard, K., Falkner, K. K., Hatakeyama, K., Moritz, R., Overland, J. E., Perovich, D., Shimada, K., Steele, M., Takizawa, T., and Woodgate, R.: North Pole Environmental Observatory delivers early results, EOS, 83, 360-361, 2002.

Müller, T., Schladitz, A., Massling, A., Kaaden, N., Kandler, K., and Wiedensohler, A.: Spectral absorption coefficients and imaginary parts of refractive indices of Saharan dust during SAMUM1, Tellus B, 61, 79-95, 2009.

Noone, K. J. and Clarke, A. D.: Soot scavenging measurement in Arctic snowfall, Atmos. Environ., 22, 2773-2778, 1988.

Ogren, J. A., Charlson, R. J., and Groblicki, P. J.: Determination of elemental carbon in rainwater, Anal. Chem., 55, 1569-1572, 1983.

Painter, T. H., Barrett, A. P., Landry, C. C., Neff, J. C., Cassidy, M. P., Lawrence, C. R., McBride, K. E., and Farmer, G. L.: Impact of disturbed desert soils on duration of mountain snow cover, Geophys. Res. Lett., 34, L12502, doi:10.1029/2007GL030284, 2007.

Perovich, D. K., Grenfell, T. C., Light, B., and Hobbs, P. V.: The seasonal evolution of Arctic sea-ice albedo, J. Geophys. Res., 107(C10), 8044, doi:10.1029/2000JC000438, 2002.

Perovich, D. K., Grenfell, T. C., Light, B., Elder, B. C., Harbeck, J., Polashenski, C., Tucker III, W. B., and Stelmach, C.: Transpolar observations of the morphological properties of Arctic sea ice, J. Geophys. Res., 114, C00A04, doi:10.1029/2008JC004892, 2009.

Potter, J. G.: Snow cover, Climatological Studies Number 3, Canada Department of Transport, Toronto, 69 pp., 1965.

Quinn, P. K., Bates, T. S., Baum, E., Doubleday, N., Fiore, A. M., Flanner, M., Fridlind, A., Garrett, T. J., Koch, D., Menon, S., Shindell, D., Stohl, A., and Warren, S. G.: Short-lived pollutants in the Arctic: their climate impact and possible mitigation strategies, Atmos. Chem. Phys., 8, 1723-1735, doi:10.5194/acp8-1723-2008, 2008.

Raatz, W. and Shaw, G. E.: Long-range tropospheric transport of pollution aerosols into the Alaskan Arctic, J. Clim. Appl. Meteor., 23, 1052-1064, 1984.

Roden, C. H., Bond, T. C., Conway, S., and Osorto Pinel, A. B.: Emission factors and real-time optical properties of particles emitted from traditional wood burning cookstoves, Environ. Sci. Technol., 40, 6750-6757, 2006.

Rosen, H., Hansen, A. D. A., Gundel, L., and Novakov, T.: Identification of the optically absorbing component in urban aerosols, Appl. Optics, 17, 3859-3861, 1978. 
Schnell, R. C.: Arctic haze and the Arctic Gas and Aerosol Sampling Program (AGASP), Geophys. Res. Lett., 11, 361-364, 1984.

Schnaiter, M., Horvath, H., Mohler, O., Naumann, K. H., Saathoff, H., and Schock, O. W.: UV-VIS-NIR spectral optical properties of soot and soot-containing aerosols, J. Aerosol Sci., 34, 14211444, 2003.

Schnaiter, M., Linke, M., Möhler, O., Naumann, K.-H., Saathoff, H., Wagner, R., Schurath, U., and Wehner, B.: Absorption amplification of black carbon internally mixed with secondary organic aerosol, J. Geophys. Res., 110, D19204, doi:10.1029/2005JD006046, 2005.

Schwerdtfeger, P. and Weller, G. E.: Radiative heat transfer processes in snow and ice, in Meteorological Studies at Plateau Station, in: Antarctica, Antarct. Res. Ser., 25, 35-39, edited by: Businger, J. A., American Geophysical Union, 1977.

Shapiro, E. L., Szprengiel, J., Sareen, N., Jen, C. N., Giordano, M. R., and McNeill, V. F.: Light-absorbing secondary organic material formed by glyoxal in aqueous aerosol mimics, Atmos. Chem. Phys., 9, 2289-2300, doi:10.5194/acp-9-2289-2009, 2009.

Sharma, S., Lavoué, D., Cachier, H., Barrie, L. A., and Gong, S. L.: Long-term trends of the black carbon concentrations in the Canadian Arctic, J. Geophys. Res., 109, D15203, doi:10.1029/2003JD004331, 2004.

Sharma, S., Andrews, E., Barrie, L. A., Ogren, J. A., and Lavoué, D.: Variations and sources of the equivalent black carbon in the high Arctic revealed by long-term observations at Alert and Barrow: 1989-2003, J. Geophys. Res., 111(D14), D14208, doi:10.1029/2005JD006581, 2006.

Shaw, G. E: The Arctic haze phenomenon, B. Am. Meteorol. Soc., 76, 2403-2413, 1995.

Slowik, J. G., Cross, E. S., Han, J.-H., Davidovits, P., Onasch, T. B., Jayne, J. T., Williams, L. R., Canagaratna, M. R., Worsnop, D. R., Chakrabarty, R. K., Moosmüller, H., Arnott, W. P., Schwartz, J. P., Gao, R.-S., Fahey, D. W., Kok, G. L., and Petzold, A.: An inter-comparison of instruments measuring black carbon content of soot particles, Aerosol Sci. Tech., 41, 295-314, 2007.

Steffen, K. and Box, J. E.: Surface climatology of the Greenland ice sheet: Greenland climate network 1995-1999, J. Geophys. Res., 106(D24), 33951-33964, 2001.

Steffen, K., Box, J. E., and Abdalati, W.: Greenland Climate Network: GC-Net, in: Glaciers, Ice Sheets and Volcanoes, edited by: Colbeck, S. C., CRREL Special Report 96-27, 98-103, US Army Cold Regions Research and Engineering Laboratory, Hanover, NH, USA, 1996.

Stroeve, J., Serreze, M., Drobot, S., Gearheard, S., Holland, M., Maslanik, J., Meier, W., and Scambos, T.: Arctic sea ice extent plummets in 2007, EOS, Trans. Amer. Geophys. Union, 89, 1314, doi:10.1029/2008EO020001, 2008.
Sturm, M., Douglas, T., Racine, C., and Liston, G. E.: Changing snow and shrub conditions affect albedo with global implications, J. Geophys. Res., 110, G01004, doi:10.1029/2005JG000013, 2005.

Sturm, M., Derksen, C., Liston, G., Silis, A., Solie, D., Holmgren, J., and Huntington, H.: A Reconnaissance Snow Survey Across Northwest Territories and Nunavut, Canada, April 2007, ERDC/CRREL Technical Report TR-08-3, US Army Corps of Engineers Cold Regions Research and Engineering Laboratory, 80 pp., 2008.

Sun, H., Biedermann, L., and Bond, T. C.: Color of brown carbon: A model for ultraviolet and visible light absorption by organic carbon aerosol, Geophys. Res. Lett., 34, L17813, doi:10.1029/2007GL029797, 2007.

Tollefson, J.: Climate's smoky spectre, Nature, 460, 29-32, 2009.

Warren, S. G.: Optical properties of snow, Rev. Geophys. Space Phys., 20, 67-89, 1982.

Warren, S. G.: Impurities in snow: effects on albedo and snowmelt, Ann. Glaciol., 5, 177-179, 1984.

Warren, S. G. and Brandt, R. E.: Optical constants of ice from the ultraviolet to the microwave: A revised compilation, J. Geophys. Res., 113, D14220, doi:10.1029/2007JD009744, 2008.

Warren, S. G. and Clarke, A. D.: Soot from arctic haze: radiative effects on the Arctic snowpack, Glaciological Data, 18, 73-77, 1986.

Warren, S. G. and Clarke, A. D.: Soot in the atmosphere and snow surface of Antarctica, J. Geophys. Res., 95, 1811-1816, 1990.

Warren, S. G. and Wiscombe, W. J.: A model for the spectral albedo of snow, II: Snow containing atmospheric aerosols, J. Atmos. Sci., 37, 2734-2745, 1980.

Warren, S. G. and Wiscombe, W. J.: Dirty snow after nuclear war, Nature, 313, 467-470, 1985.

Warren, S. G., Rigor, I. G., Untersteiner, N., Radionov, V. F., Bryazgin, N. N., Aleksandrov, Ye. I., and Colony, R.: Snow depth on Arctic sea ice, J. Climate, 12, 1814-1829, 1999.

Warren, S. G., Brandt, R. E., and Grenfell, T. C.: Visible and nearultraviolet absorption spectrum of ice from transmission of solar radiation into snow, Appl. Optics, 45, 5320-5334, 2006.

Watson, J. G., Chow, J. C., and Chen, L.-W. A.: Summary of organic and elemental carbon/black carbon analysis methods and intercomparisons, Aerosol Air Qual. Res., 5, 65-102, 2005.

Wiscombe, W. J. and Warren, S. G.: A model for the spectral albedo of snow, I: Pure snow, J. Atmos. Sci., 37, 2712-2733, 1980.

Yang, M., Howell, S. G., Zhuang, J., and Huebert, B. J.: Attribution of aerosol light absorption to black carbon, brown carbon, and dust in China - interpretations of atmospheric measurements during EAST-AIRE, Atmos. Chem. Phys., 9, 2035-2050, doi:10.5194/acp-9-2035-2009, 2009. 